\title{
Groundwater, Surface-Water, and Water-Chemistry Data, Black Mesa Area, Northeastern Arizona-2007-2008
}

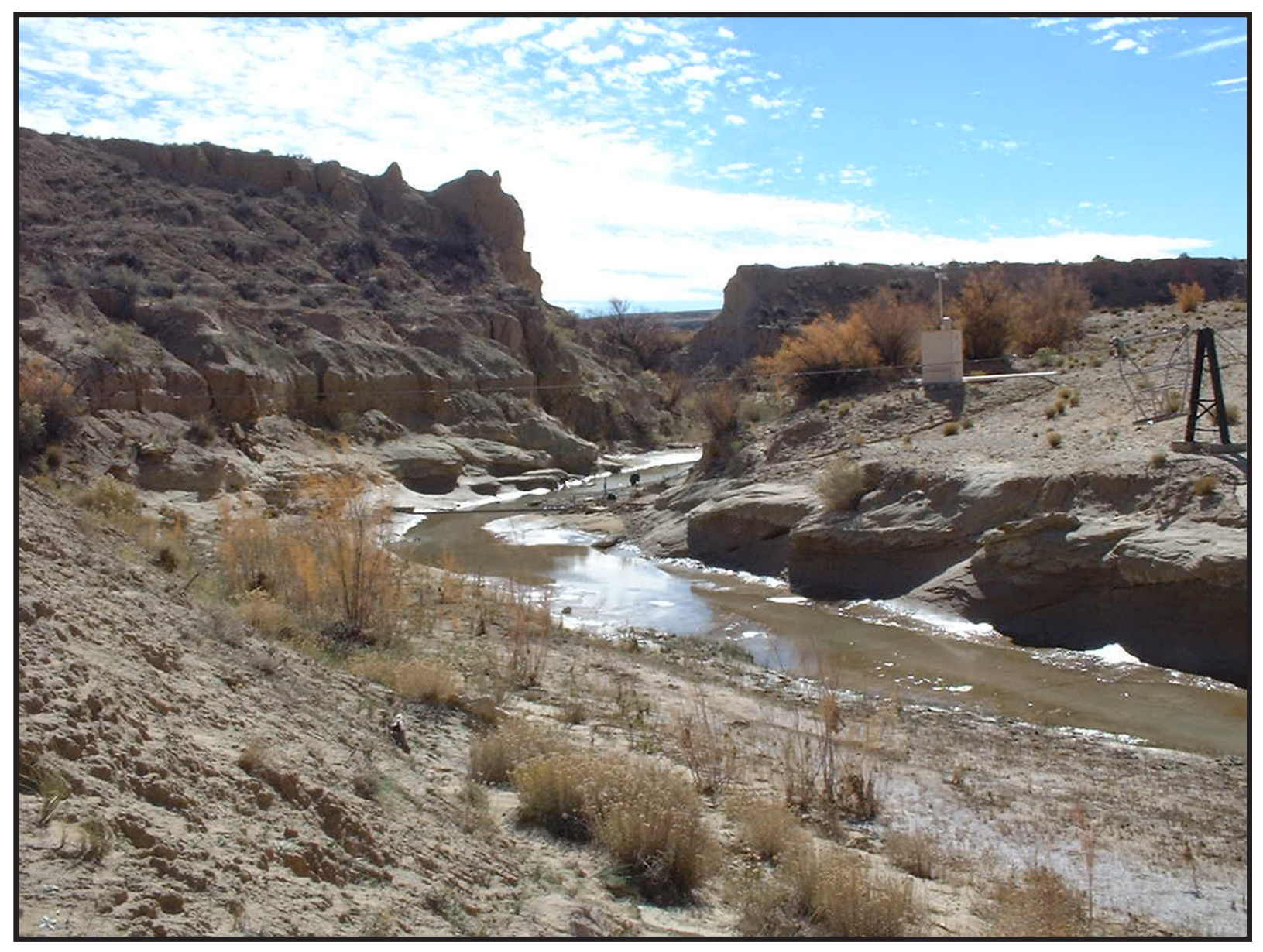

Prepared in cooperation with the BUREAU OF INDIAN AFFAIRS and the ARIZONA DEPARTMENT OF WATER RESOURCES

Open-File Report 2009-1148 
COVER:

This photograph is looking upstream at USGS streamflow gaging station Dinnebito Wash near Sand Springs, AZ (09401110) 


\section{Groundwater, Surface-Water, and Water- Chemistry Data, Black Mesa Area, Northeastern Arizona—2007-2008}

By Jamie P. Macy

Prepared in cooperation with the

BUREAU OF INDIAN AFFAIRS and the

ARIZONA DEPARTMENT OF WATER RESOURCES

Open-File Report 2009-1148 


\section{U.S. Department of the Interior KEN SALAZAR, Secretary}

\section{U.S. Geological Survey Suzette M. Kimball, Acting Director}

U.S. Geological Survey, Reston, Virginia: 2009

This report and any updates to it are available online at:

http://pubs.usgs.gov/of/2009/1148/

For product and ordering information:

World Wide Web: http://www.usgs.gov/pubprod

Telephone: 1-888-ASK-USGS (1-888-275-8747)

For more information on the USGS — the Federal source for science about the Earth, its natural and living resources, natural hazards, and the environment:

World Wide Web: http://www.usgs.gov/

Telephone: 1-888-ASK-USGS (1-888-275-8747)

Any use of trade, product, or firm names in this publication is for descriptive purposes only and does not imply endorsement by the U.S. Government.

Although this report is in the public domain, permission must be secured from the individual copyright owners to reproduce any copyrighted materials contained within this report.

Suggested citation:

Macy, Jamie P., 2009, Groundwater, surface-water, and water-chemistry data, Black Mesa area, northeastern Arizona-2007-2008: U.S. Geological Survey Open-File Report 2009-1148, 43 p.

Cataloging-in-publication data are on file with the Library of Congress (URL http://www.loc.gov/). 


\section{Contents}

Abstract
Introduction
Purpose and Scope
Hydrologic Data Investigations.
$\quad$ Withdrawals from the N Aquifer
$\quad$ Groundwater Levels in the N Aquifer
$\quad$ Surface-Water Discharge
$\quad$ Water Chemistry
$\quad$ Water-Chemistry Data for Wells Completed in the N Aquifer rem

\section{Figures}

1. Map showing location of study area, Black Mesa area, northeastern Arizona.

2. Diagram showing rock formations and hydrogeologic units of the Black Mesa area, northeastern Arizona.....

3. Graph showing annual withdrawals from the $\mathrm{N}$ aquifer, Black Mesa area, northeastern Arizona, 1965-2007.

4. Map showing locations of well systems monitored for annual withdrawals from the $\mathrm{N}$ aquifer, Black Mesa area, northeastern Arizona, calendar year 2007.

5. Map showing water-level changes in $\mathrm{N}$-aquifer wells from the prestress period (prior to 1965 ) to 2008, Black Mesa area, northeastern Arizona.

6. Graphs showing observed water levels (1950-2008) in annual observation-well network, $\mathrm{N}$ aquifer, Black Mesa area, northeastern Arizona .................................16-19

7. Graph showing observed water-level changes in continuous-record observation wells, BM1-BM6, 1963-2008, N aquifer, Black Mesa area, northeastern Arizona

8. Map showing surface-water and water-chemistry data-collection sites, $\mathrm{N}$ aquifer, Black Mesa area, northeastern Arizona, 2007-8

9. Graphs showing discharge from Moenkopi School Spring and Pasture Canyon Spring, $\mathrm{N}$ aquifer, northeastern Black Mesa area, northeastern Arizona, 1987-2008 ............22

10. Graphs showing annual average discharge at Moenkopi Wash at Moenkopi (09401260), Pasture Canyon Spring (09401265), Dinnebito Wash near Sand Springs (09401110), and Polacca Wash near Second Mesa (09400568), and annual precipitation at Betatakin, Arizona, Black Mesa area, northeastern Arizona .... 
11. Graphs showing median winter flow for November, December, January, and February for water years 1977-2007 for Moenkopi Wash at Moenkopi (09401260), Dinnebito Wash near Sand Spring (09401110), and Polacca Wash near Second Mesa (09400568), Black Mesa area, northeastern Arizona

12. Map showing water chemistry and distribution of dissolved solids in the $\mathrm{N}$ aquifer, Black Mesa area, northeastern Arizona, 2008 .32

13. Graph showing dissolved-solids concentrations for water samples from selected wells, $\mathrm{N}$ aquifer, Black Mesa area, northeastern Arizona, 1974-2008. 35-36

14. Graph showing concentrations of dissolved solids, chloride, and sulfate for water samples from Moenkopi School Spring and Pasture Canyon Spring, N aquifer, Black Mesa area, northeastern Arizona, 1982-2008. 39

\section{Tables}

1. Withdrawals from the $\mathrm{N}$ aquifer, Black Mesa area, northeastern Arizona, 1965-2007

2. Identification numbers and names of monitoring program study wells, 2007-8, Black Mesa area, northeastern Arizona

3. Withdrawals from the $\mathrm{N}$ aquifer by well system, Black Mesa area, northeastern Arizona, calendar year 2007

4. Total, industrial, and municipal withdrawals from the $\mathrm{N}$ aquifer for discrete time periods during 1965 to 2007, Black Mesa area, northeastern Arizona.

5. Water-level changes in monitoring program wells completed in the $\mathrm{N}$ aquifer, Black Mesa area, northeastern Arizona, calendar year, prestress period to 2008 (calendar year)

6. Well-construction characteristics, depth to top of $\mathrm{N}$ aquifer, and type of data collected for wells in monitoring program, Black Mesa area, northeastern Arizona, 2007-8.

7. Median changes in water levels in monitoring-program wells, 2007-8 and prestress period (prior to 1965) to 2008, N aquifer, Black Mesa area, northeastern Arizona.

8. Discharge measurements for Moenkopi School Spring and Pasture Canyon Spring, Black Mesa area, northeastern Arizona, 1952-2008.

9. Discharge data (daily mean values), Moenkopi Wash at Moenkopi, Arizona (09401260), calendar year 2007

10. Discharge data (daily mean values), Dinnebito Wash near Sand Springs, Arizona (09401110), calendar year 2007

11. Discharge data (daily mean values), Polacca Wash near Second Mesa, Arizona (09400568), calendar year 2007

12. Discharge data (daily mean values), Pasture Canyon Springs near Tuba City, Arizona (09401265), calendar year 2007

13. Date that streamflow data collection began and drainage areas for streamflow-gaging stations, Black Mesa area, northeastern Arizona

14. Physical properties and chemical analyses of water samples from selected industrial and municipal wells completed in the $\mathrm{N}$ aquifer, Black Mesa area, northeastern Arizona, 2008. 
15. Specific conductance and concentrations of selected chemical constituents in water from selected industrial and municipal wells completed in the $\mathrm{N}$ aquifer, Black

Mesa area, northeastern Arizona, 1974-2008

16. Physical properties and chemical analyses of water samples from Moenkopi School Spring and Pasture Canyon Spring, Black Mesa area, northeastern Arizona, 2008.

17. Specific conductance and concentrations of selected chemical constituents in $\mathrm{N}$-aquifer water samples from Moenkopi School Spring and Pasture Canyon Spring, Black Mesa area, northeastern Arizona, 1948-2008...

\section{Conversion Factors and Datum}

\begin{tabular}{lcl}
\hline Multiply & By & To obtain \\
\hline & Length & \\
\hline inch (in.) & 2.54 & centimeter $(\mathrm{cm})$ \\
inch (in.) & 25.4 & millimeter $(\mathrm{mm})$ \\
foot (ft) & 0.3048 & meter $(\mathrm{m})$ \\
mile (mi) & 1.609 & kilometer $(\mathrm{km})$ \\
\hline & Area & \\
\hline square mile (mir) & 2.590 & square kilometer $(\mathrm{km})$ \\
\hline & Volume & \\
\hline acre-foot (acre-ft) & 0.001233 & cubic hectometer $(\mathrm{hm})$ \\
\hline & Flow rate & \\
\hline cubic foot per second $(\mathrm{ft} / \mathrm{s})$ & 0.02832 & cubic meter per second $(\mathrm{m} / \mathrm{s})$ \\
gallon per minute $(\mathrm{gal} / \mathrm{min})$ & 0.06309 & liter per second $(\mathrm{L} / \mathrm{s})$ \\
\hline
\end{tabular}

Temperature in degrees Celsius $\left({ }^{\circ} \mathrm{C}\right)$ may be converted to degrees Fahrenheit $\left({ }^{\circ} \mathrm{F}\right)$ as follows: ${ }^{\circ} \mathrm{F}=\left(1.8 x^{\circ} \mathrm{C}\right)+32$

Vertical coordinate information is referenced to the National Geodetic Vertical Datum of 1929 (NGVD 29). Altitude, as used in this report, refers to distance above the vertical datum.

Horizontal coordinate information is referenced to the North American Datum of 1927 (NAD 27).

Specific conductance is given in microsiemens per centimeter at 25 degrees Celsius $\left(\mu \mathrm{S} / \mathrm{cm}\right.$ at $\left.25^{\circ} \mathrm{C}\right)$.

Concentrations of chemical constituents in water are given either in milligrams per liter (mg/L) or micrograms per liter $(\mu \mathrm{g} / \mathrm{L})$. 
This page left blank intentionally. 


\title{
Groundwater, Surface-Water, and Water-Chemistry Data, Black Mesa Area, Northeastern Arizona-2007-2008
}

\author{
By Jamie P. Macy
}

\section{Abstract}

The $\mathrm{N}$ aquifer is an extensive aquifer and the primary source of groundwater in the 5,400-square-mile Black Mesa area in northeastern Arizona. Availability of water is an important issue in northeastern Arizona because of continued water requirements for industrial and municipal use by a growing population and because of low precipitation in the arid climate of the Black Mesa area, which is typically about 6 to 14 inches per year.

The U.S. Geological Survey water-monitoring program in the Black Mesa area began in 1971 and provides information about the long-term effects of groundwater withdrawals from the $\mathrm{N}$ aquifer for industrial and municipal uses. This report presents results of data collected as part of the monitoring program in the Black Mesa area from January 2007 to September 2008. The monitoring program includes measurements of (1) groundwater withdrawals, (2) groundwater levels, (3) spring discharge, (4) surface-water discharge, and (5) groundwater chemistry.

In 2007, total groundwater withdrawals were 4,270 acre-feet, industrial withdrawals were 1,170 acre-ft, and municipal withdrawals were 3,100 acre-ft. Total withdrawals during 2007 were about 41 percent less than total withdrawals in 2005. From 2006 to 2007, however, total withdrawals increased by 4 percent, industrial withdrawals decreased by approximately 2 percent, and total municipal withdrawals increased by 7 percent.

From 2007 to 2008, annually measured water levels in the Black Mesa area declined in 6 of 11 wells measured in the unconfined areas of the $\mathrm{N}$ aquifer, and the median change was -0.2 feet. Water levels declined in 9 of 18 wells measured in the confined area of the aquifer. The median change for the confined area of the aquifer was -0.2 feet. From the prestress period (prior to 1965 ) to 2008 , the median water-level change for 33 wells in both the confined and unconfined area was -12.9 feet. Median water-level changes were -1.0 feet for 15 wells measured in the unconfined areas and -33.2 feet for 18 wells measured in the confined area.

Spring flow was measured at two springs in 2008. Flow decreased at both Moenkopi School Spring and Pasture Canyon Spring from previous years. Flow fluctuated during the period of record, but a decreasing trend was apparent.
Continuous records of surface-water discharge in the Black Mesa area were collected from streamflow-gaging stations at the following sites: Moenkopi Wash at Moenkopi 09401260 (1976 to 2007), Dinnebito Wash near Sand Springs 09401110 (1993 to 2007), Polacca Wash near Second Mesa 09400568 (1994 to 2007), and Pasture Canyon Springs 09401265 (August 2004 to 2007). Median winter flows (November through February) of each water year were used as an index of the amount of groundwater discharge at the abovenamed sites. For the period of record of each streamflow-gaging station, the median winter flows have generally remained constant, which suggests no change in groundwater. The period of record is too short to determine if there is a trend at Pasture Canyon Spring.

In 2008, water samples collected from 6 wells and 2 springs in the Black Mesa area were analyzed for selected chemical constituents and the results compared with previous analyses. Concentrations of dissolved solids, chloride, and sulfate have varied at all 6 wells for the period of record, but neither increasing nor decreasing trends over time were found. Dissolved-solids, chloride, and sulfate concentrations increased at Moenkopi School Spring during the more than 12 years of record at that site. Concentrations of dissolved solids, chloride, and sulfate at Pasture Canyon Spring have not varied much since the early 1980's, and there is no trend in those data.

\section{Introduction}

The 5,400-square-mile Black Mesa study area in northeastern Arizona contains a diverse topography that includes flat plains, mesas, and incised drainages (fig. 1). Black Mesa is a topographic high at the center of the study area that covers about 2,000 $\mathrm{mi}^{2}$. It has 2,000-foot-high cliffs on its northern and northeastern sides, but slopes gradually down to the south and southwest. Availability of water is an important issue in the study area because of continued groundwater withdrawals, the growing population, and average annual precipitation in the arid to semiarid climate ranges between 6 and 14 in. (U.S. Department of Agriculture, 1999). The Navajo (N) aquifer is the major source of water for industrial and municipal uses 


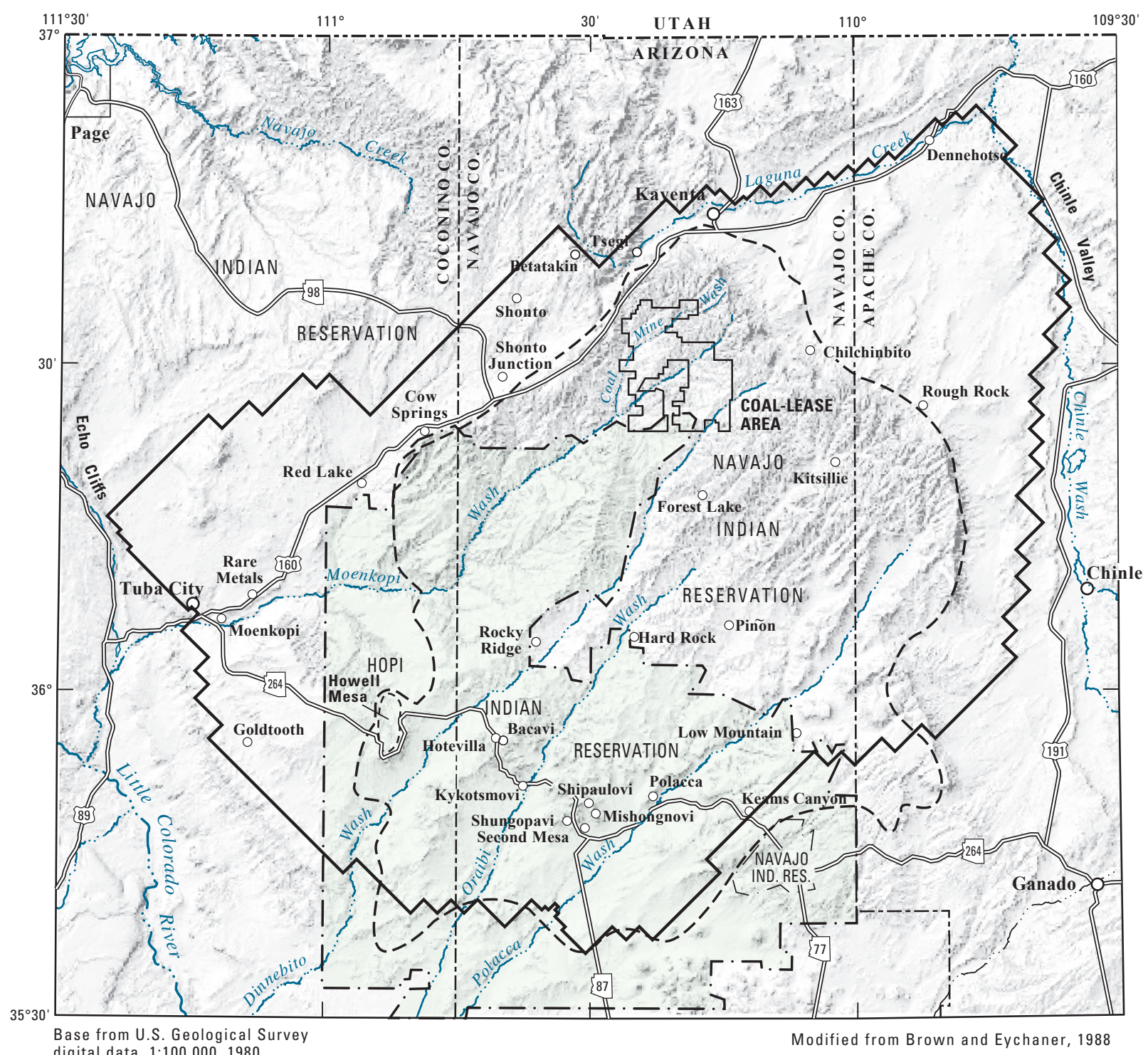
digital data, 1:100,000, 1980

Lambert Conformal Conic projection Standard parallels $29^{\circ} 30^{\prime}$ and $45^{\circ} 30^{\prime}$, central meridian $-111^{\circ} 30^{\prime}$
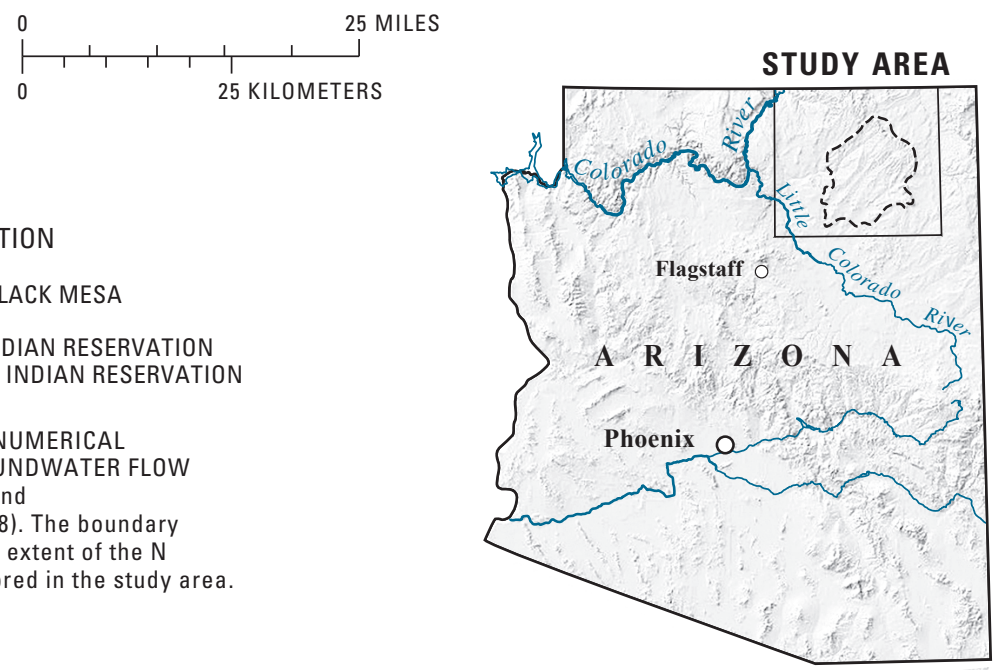

Figure 1. Location of study area, Black Mesa area, northeastern Arizona. 
in the Black Mesa area. The $\mathrm{N}$ aquifer is composed of three hydraulically connected formations - the Navajo Sandstone, the Kayenta Formation, and the Lukachukai Member of the Wingate Sandstone - that function as a single aquifer (fig. 2).

The $\mathrm{N}$ aquifer is confined under most of Black Mesa, and the overlying stratigraphy limits recharge to this part of the aquifer. The $\mathrm{N}$ aquifer is unconfined in areas surrounding Black Mesa, and most recharge occurs where the Navajo Sandstone is exposed in the area near Shonto (fig. 1) (Lopes and Hoffmann, 1997).

Within the Black Mesa study area, the Navajo Nation and Hopi Tribe are the principal municipal water users and Peabody Western Coal Company (PWCC) is the principal industrial water user. Withdrawals from the $\mathrm{N}$ aquifer in the Black Mesa area have been increasing during the past 40 years (table 1). PWCC began operating a strip mine in the northern part of the study area in 1968 (fig. 1). The quantity of water pumped by PWCC increased from about 100 acre-ft in 1968 to a maximum of 4,740 acre-ft in 1982. In 2005, PWCC pumped about 4,480 acre-ft of water. Withdrawals from the $\mathrm{N}$ aquifer for municipal use increased from an estimated 250 acre-ft in 1968 to 2,850 acre-ft in 2005. The period before appreciable groundwater withdrawals began for mining or municipal purposes (about 1965) is referred to in this report as the prestress period. On December 31, 2005, PWCC reduced pumping of the $\mathrm{N}$ aquifer by approximately 70 percent as a result of discontinued use of a coal slurry pipeline. PWCC planned on continuing to pump approximately 1,000 to 1,500 acre-ft per year, primarily for dust control. In 2006 and 2007 PWCC pumped about 1,200 acre$\mathrm{ft}$ of water per year (table 1).

The members of the Navajo Nation and the Hopi Tribe have been concerned about the long-term effects of withdrawals from the $\mathrm{N}$ aquifer on available groundwater supplies, on stream and spring discharge, and on groundwater chemistry. In 1971, these water-supply concerns led to the establishment of a monitoring program for the water resources in the Black Mesa area by the U.S. Geological Survey (USGS) in cooperation with the Arizona Water Commission, which was the predecessor to the present Arizona Department of Water Resources (ADWR). In 1983, the Bureau of Indian Affairs (BIA) joined the cooperative effort. Since 1983, the Navajo Tribal Utility Authority (NTUA), PWCC, the Hopi Tribe, and the Western Navajo, Chinle, and Hopi Agencies of the BIA have assisted in the collection of hydrologic data.

\section{Purpose and Scope}

This report presents results of groundwater, surfacewater, and water-chemistry monitoring in the Black Mesa area from January 2007 to September 2008. Continuous and periodic groundwater and surface-water data are collected to determine the effects of industrial and municipal withdrawals from the $\mathrm{N}$ aquifer on groundwater levels, stream and spring discharge, and groundwater chemistry. Groundwater data include water levels, spring-discharge rates, and water chemistry. Surface-water data include discharge rates at four continuous-record streamflow-gaging stations.

\section{Previous Investigations}

Twenty-five progress reports on the Black Mesa area monitoring program have been prepared by the USGS (U.S. Geological Survey, 1978; G.W. Hill, Hydrologist, written commun., 1982, 1983; Hill, 1985; Hill and Whetten, 1986; Hill and Sottilare, 1987; Hart and Sottilare, 1988, 1989; Sottilare, 1992; Littin, 1992, 1993; Littin and Monroe, 1995a, 1995b, 1996, 1997; Littin and others, 1999; Truini and others, 2000; Thomas and Truini, 2000; Thomas, 2002a, 2002b; Truini and Thomas, 2004; Truini and others, 2005; Truini and Macy, 2006, 2007, 2008). Most of the data from the Black Mesa area monitoring program are contained in these progress reports and in the USGS National Water Information System (NWIS) database (http://waterdata.usgs.gov/ $a z / n w i s /$ ). Stream-discharge and periodic water-quality data collected from Moenkopi Wash before the 1982 water year were published by the U.S. Geological Survey (1963-64a, b; 1965-74a, b; and 1976-83). Stream-discharge data from water years 1983 to 2003 for Moenkopi Wash at Moenkopi (09401260), Dinnebito Wash near Sand Springs (09401110), Polacca Wash near Second Mesa (09400568), Laguna Creek at Dennehotso (09379180), and Pasture Canyon Spring (09401265) in the Black Mesa area were published in White and Garrett (1984, 1986, 1987, 1988), Wilson and Garrett (1988, 1989), Boner and others (1989, 1990, 1991, 1992), Smith and others (1993, 1994, 1995, 1996, 1997), Tadayon and others $(1998,1999,2000,2001)$, McCormack and others (2002, 2003), Fisk and others $(2004,2005)$, and online at (http://wdr.water.usgs.gov/wy2006/search.jsp) in the 2006 annual data report. Before the monitoring program, a large data-collection effort in the 1950s resulted in a compilation of well and spring data for the Navajo and Hopi Indian Reservations (Davis and others, 1963).

Many interpretive studies have investigated the hydrology of the Black Mesa area. Cooley and others (1969) made the first comprehensive evaluation of the regional hydrogeology of the Black Mesa area. Eychaner (1983) developed a two-dimensional numerical model of groundwater flow in the $\mathrm{N}$ aquifer. Brown and Eychaner (1988) recalibrated Eychaner's model by using a finer grid and using revised estimates of selected aquifer characteristics. GeoTrans, Inc. (1987) also developed a two-dimensional numerical model of the $\mathrm{N}$ aquifer in the 1980s. In the late 1990s, HSIGeoTrans, Inc., and Waterstone Environmental Hydrology and Engineering(1999) developed a detailed three-dimensional numerical model of the $\mathrm{N}$ aquifer and the overlying Dakota (D) aquifer.

Kister and Hatchett (1963) made the first comprehensive evaluation of the chemistry of water collected from wells and springs in the Black Mesa area. HSIGeoTrans, Inc. (1993) evaluated the major-ion and isotopic chemistry of the $\mathrm{D}$ and $\mathrm{N}$ aquifers. Lopes and Hoffmann (1997) analyzed groundwater 


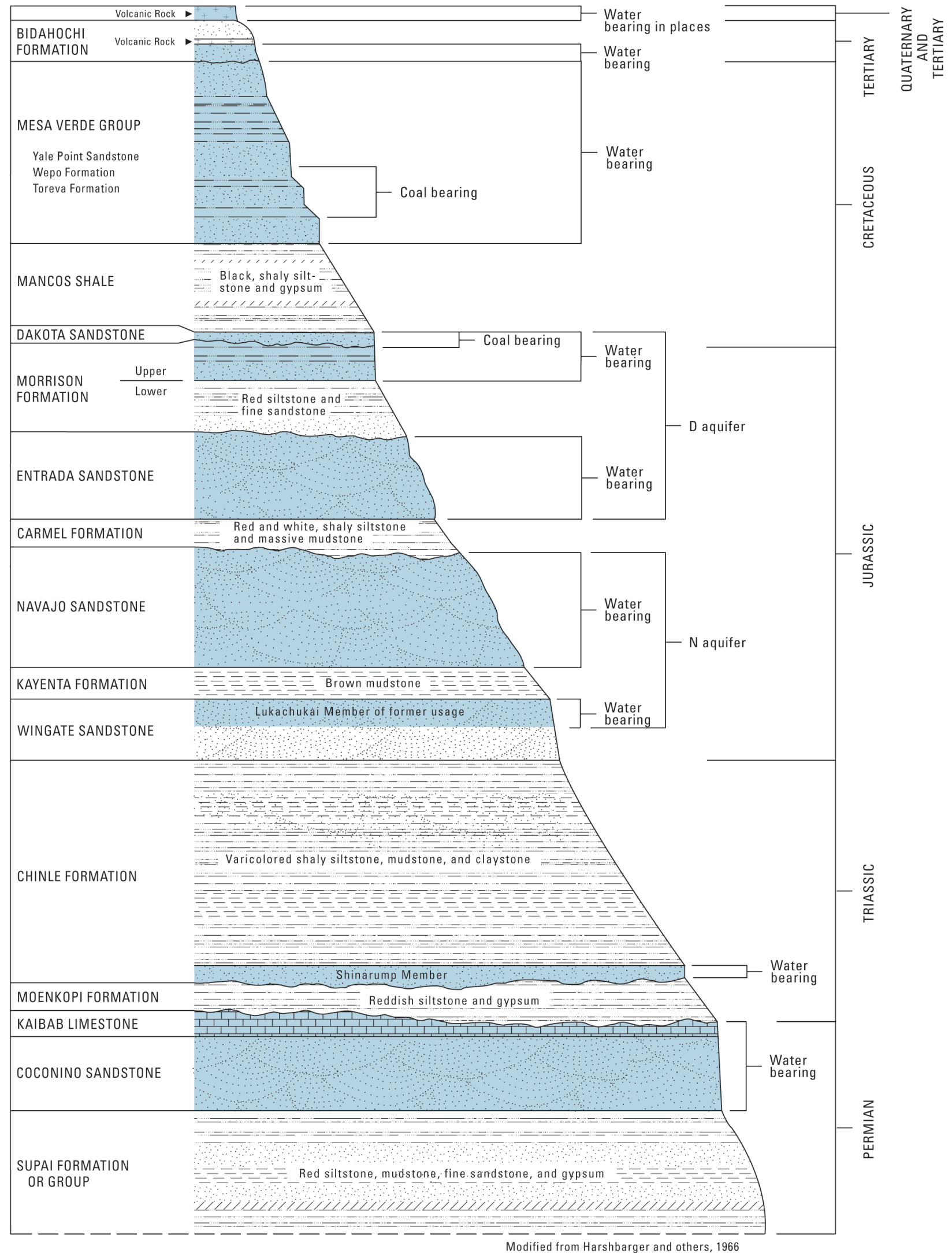

Figure 2. Rock formations and hydrogeologic units of the Black Mesa area, Arizona (not to scale). The $\mathrm{N}$ aquifer is approximately 1,000 feet thick. 
Table 1. Withdrawals from the $\mathrm{N}$ aquifer, Black Mesa area, northeastern Arizona, 1965-2007.

[Values are rounded to nearest 10 acre-feet. Data for 1965-79 from Eychaner (1983). Total withdrawals in Littin and Monroe (1996) were for the confined area of the aquifer]

\begin{tabular}{|c|c|c|c|c|}
\hline \multirow[b]{2}{*}{ Calendar Year } & \multirow[t]{2}{*}{ Industrial1 $^{1}$} & \multicolumn{2}{|c|}{ Municipal $^{2,3}$} & \multirow[b]{2}{*}{ Total withdrawals } \\
\hline & & Confined & Unconfined & \\
\hline 1965 & 0 & 50 & 20 & 70 \\
\hline 1966 & 0 & 110 & 30 & 140 \\
\hline 1967 & 0 & 120 & 50 & 170 \\
\hline 1968 & 100 & 150 & 100 & 350 \\
\hline 1969 & 40 & 200 & 100 & 340 \\
\hline 1970 & 740 & 280 & 150 & 1,170 \\
\hline 1971 & 1,900 & 340 & 150 & 2,390 \\
\hline 1972 & 3,680 & 370 & 250 & 4,300 \\
\hline 1973 & 3,520 & 530 & 300 & 4,350 \\
\hline 1974 & 3,830 & 580 & 360 & 4,770 \\
\hline 1975 & 3,500 & 600 & 510 & 4,610 \\
\hline 1976 & 4,180 & 690 & 640 & 5,510 \\
\hline 1977 & 4,090 & 750 & 730 & 5,570 \\
\hline 1978 & 3,000 & 830 & 930 & 4,760 \\
\hline 1979 & 3,500 & 860 & 930 & 5,290 \\
\hline 1980 & 3,540 & 910 & 880 & 5,330 \\
\hline 1981 & 4,010 & 960 & 1,000 & 5,970 \\
\hline 1982 & 4,740 & 870 & 960 & 6,570 \\
\hline 1983 & 4,460 & 1,360 & 1,280 & 7,100 \\
\hline 1984 & 4,170 & 1,070 & 1,400 & 6,640 \\
\hline 1985 & 2,520 & 1,040 & 1,160 & 4,720 \\
\hline 1986 & 4,480 & 970 & 1,260 & 6,710 \\
\hline 1987 & 3,830 & 1,130 & 1,280 & 6,240 \\
\hline 1988 & 4,090 & 1,250 & 1,310 & 6,650 \\
\hline 1989 & 3,450 & 1,070 & 1,400 & 5,920 \\
\hline 1990 & 3,430 & 1,170 & 1,210 & 5,810 \\
\hline 1991 & 4,020 & 1,140 & 1,300 & 6,460 \\
\hline 1992 & 3,820 & 1,180 & 1,410 & 6,410 \\
\hline 1993 & 3,700 & 1,250 & 1,570 & 6,520 \\
\hline 1994 & 4,080 & 1,210 & 1,600 & 6,890 \\
\hline 1995 & 4,340 & 1,220 & 1,510 & 7,070 \\
\hline 1996 & 4,010 & 1,380 & 1,650 & 7,040 \\
\hline 1997 & 4,130 & 1,380 & 1,580 & 7,090 \\
\hline 1998 & 4,030 & 1,440 & 1,590 & 7,060 \\
\hline 1999 & 4,210 & 1,420 & 1,480 & 7,110 \\
\hline 2000 & 4,490 & 1,610 & 1,640 & 7,740 \\
\hline 2001 & 4,530 & 1,490 & 1,660 & 7,680 \\
\hline 2002 & 4,640 & 1,500 & 1,860 & 8,000 \\
\hline 2003 & 4,450 & 1,350 & 1,440 & 7,240 \\
\hline 2004 & 4,370 & 1,240 & 1,600 & 7,210 \\
\hline 2005 & 4,480 & 1,280 & 1,570 & 7,330 \\
\hline 2006 & 1,200 & ${ }^{4} 1,300$ & ${ }^{4} 1,600$ & 44,100 \\
\hline 2007 & 1,170 & 1,460 & 1,640 & 4,270 \\
\hline
\end{tabular}

${ }^{1}$ Metered pumpage from the confined part of the aquifer by Peabody Western Coal Company.

${ }^{2}$ Does not include withdrawals from the wells equipped with windmills.

${ }^{3}$ Includes estimated pumpage 1965-73 and metered pumpage 1974-79 at Tuba City; metered pumpage at Kayenta and estimated pumpage at Chilchinbito, Rough Rock, Piñon, Keams Canyon, and Kykotsmovi before 1980; metered and estimated pumpage furnished by the Navajo Tribal Utility Authority and the Bureau of Indian Affairs and collected by the U.S. Geological Survey, 1980-85; and metered pumpage furnished by the Navajo Tribal Utility Authority, the Bureau of Indian Affairs, various Hopi Village Administrations, and the U.S. Geological Survey, $1986-2007$.

${ }^{4}$ NTUA meter data was not available for 2006; therefore municipal withdrawals are estimated, and total withdrawal uses an estimation in the calculation. 
ages, recharge, and hydraulic conductivity of the $\mathrm{N}$ aquifer by using geochemical techniques. Zhu and others (1998) estimated groundwater recharge in the Black Mesa area by using isotopic data and flow estimates from the $\mathrm{N}$-aquifer model developed by GeoTrans, Inc. (1987). Zhu (2000) estimated recharge using advective transport modeling and the same isotopic data from the GeoTrans model. Truini and Longsworth (2003) described the hydrogeology of the D aquifer and the movement and ages of groundwater in the Black Mesa area by using data from geochemical and isotopic analyses. Truini and Macy (2005) addressed leakage through the confining unit between the $\mathrm{D}$ aquifer and the $\mathrm{N}$ aquifer as part of an investigation of the Carmel Formation.

\section{Hydrologic Data}

In 2007-8, activities of the Black Mesa area monitoring program included metered groundwater withdrawals, measurements of groundwater levels, streamflow gaging, spring discharge measurements, and the collection of water-chemistry samples from wells and springs. Linear regression trend analyses were applied to streamflow data, spring discharge, and waterchemistry samples. Annual discharge measurements were made at 2 springs, and annual groundwater-level measurements were made at 34 wells. Of those 34 wells, 6 are continuous-recording observation wells that have been upgraded for real-time data telemetry. The water-level data from these six continuous-recording observation wells are available on the World Wide Web (http://waterdata.usgs.gov/az/nwis/rt). Groundwater withdrawal data were collected from January to December 2007. Spring discharges and groundwater levels were measured from January to June 2008. Groundwater samples were collected from six wells and two springs in June 2008 and were analyzed for chemical constituents. Annual groundwater withdrawal data are collected from 28 well systems within the NTUA, BIA, and Hopi municipal systems and the PWCC industrial well field. Identification information for the 34 wells used for water-level measurements and water-quality sampling is shown in table 2 . All annual data reported in this document are for calendar years beginning January 1 and ending December 31 .

\section{Withdrawals from the $\mathbf{N}$ Aquifer}

Total withdrawals from the $\mathrm{N}$ aquifer are monitored on a continuing basis to determine the effects from industrial and municipal pumping. Withdrawals from the $\mathrm{N}$ aquifer are separated into three categories: (1) industrial withdrawals from the confined area, (2) municipal withdrawals from the confined area, and (3) municipal withdrawals from the unconfined areas. The industrial category includes eight wells in the PWCC well field in the northern Black Mesa area. The BIA, NTUA, and Hopi Tribe operate about 70 municipal wells that are combined into 28 well systems. Information about withdrawals from the $\mathrm{N}$ aquifer is compiled primarily on the basis of metered data from individual wells operated by the BIA, NTUA, and Hopi Tribe (table 3).

Withdrawals from wells equipped with windmills are not measured in this monitoring program. About 270 windmills in the Black Mesa area withdraw water from the D and $\mathrm{N}$ aquifers, and the estimated total withdrawal by the windmills is about 65 acre-ft/yr (HSIGeoTrans, Inc., and Waterstone Environmental Hydrology and Engineering, Inc., 1999). The total withdrawal by the windmills is less than 1 percent of the total annual withdrawal from the $\mathrm{N}$ aquifer.

In 2007, the total groundwater withdrawal from the $\mathrm{N}$ aquifer was about 4,270 acre-ft (table 1). Withdrawals for municipal use from the confined area totaled 1,460 acre-ft. Withdrawals for municipal use from the unconfined areas totaled 1,640 acre-ft. Withdrawals for industrial use totaled 1,170 acre-ft, a 2-percent decrease from 2006, and withdrawals for municipal use totaled 3,100 acre- $\mathrm{ft}$ (table 4).

Withdrawals from the $\mathrm{N}$ aquifer have varied from 1965 to the present but generally increased from 1965 to 2005 and decreased between 2005 and 2006. On December 31, 2005, Peabody Western Coal Company reduced their pumping by 70 percent, which reflected a decrease in total annual withdrawals from 2005 by about 44 percent (tables 1 and 4, fig. 3). Total withdrawal for the period of record 1965-2007 totaled 226,670 acre-ft; industrial withdrawals were 62 percent and municipal withdrawals 38 percent of total withdrawals (table 4). From 1965 to 1972 , total annual withdrawals increased from 70 to 4,300 acre-ft; industrial withdrawals were 72 percent and municipal withdrawals 28 percent of total withdrawals (table 4). From 1973 to 1984, withdrawals totaled 66,470 acre-ft; industrial withdrawals were 70 percent and municipal withdrawals 30 percent of total withdrawals (table 4). In 1985, withdrawals totaled 4,720 acre-ft; industrial withdrawals were 53 percent and municipal withdrawals 47 percent of total withdrawals. From 1986 to 2004, withdrawals totaled 130,850 acre-ft; industrial withdrawals were 60 percent and municipal withdrawals 40 percent of total withdrawals (table 4). The last of the years of increasing withdrawals was 2005, and total withdrawals for that year were 7,330 acre-ft; industrial withdrawals were 61 percent and municipal withdrawals 39 percent of total withdrawals (table 4). 2006 marks a distinct change in the amount of water being pumped from the $\mathrm{N}$ aquifer; industrial withdrawals only accounted for about 29 percent of the total withdrawals compared to 61 percent the previous year (table 4). Municipal withdrawals in 2006 were about 71 percent of the total withdrawals, although there is some uncertainty to this number because NTUA metered data were not available for 2006 and therefore had to be estimated based on a 1-percent increase from the year before. Withdrawals in 2007 were much the same as in 2006. Total withdrawals were 4,270 acre-ft, with 27 percent coming from industrial withdrawals and 73 percent from municipal withdrawals (table 4). 
Table 2. Identification numbers and names of monitoring program study wells, 2007-8, Black Mesa area, northeastern Arizona.

[Dashes indicate no data]

\begin{tabular}{|c|c|c|}
\hline $\begin{array}{l}\text { U.S. Geological Survey } \\
\text { identification number }\end{array}$ & Common name or location & $\begin{array}{l}\text { Bureau of } \\
\text { Indian Affairs } \\
\text { site number }\end{array}$ \\
\hline 355023110182701 & Keams Canyon PM2 & --- \\
\hline 355215110375001 & Kykotsmovi PM2 & --- \\
\hline 355230110365801 & Kykotsmovi PM1 & --- \\
\hline 355236110364501 & Kykotsmovi PM3 & --- \\
\hline 355428111084601 & Goldtooth & $3 \mathrm{~A}-28$ \\
\hline 355924110485001 & Howell Mesa & $3 \mathrm{~K}-311$ \\
\hline 360055110304001 & BM observation well 5 & $4 \mathrm{~T}-519$ \\
\hline 360217111122601 & Tuba City & $3 \mathrm{~K}-325$ \\
\hline 360527110122501 & Piñon NTUA 1 & --- \\
\hline 360614110130801 & Piñon PM6 & --- \\
\hline 360734111144801 & Tuba City & $3 \mathrm{~T}-333$ \\
\hline 360904111140201 & Tuba City NTUA 1 & $3 \mathrm{~T}-508$ \\
\hline 360918111080701 & Tuba City Rare Metals 2 & --- \\
\hline 360924111142201 & Tuba City NTUA 3 & --- \\
\hline 360953111142401 & Tuba City NTUA 4 & $3 \mathrm{~T}-546$ \\
\hline 361225110240701 & BM observation well 6 & --- \\
\hline 361737110180301 & Forest Lake NTUA 1 & $4 \mathrm{~T}-523$ \\
\hline 361832109462701 & Rough Rock & $10 \mathrm{~T}-258$ \\
\hline 362043110030501 & Kits'iili NTUA 2 & --- \\
\hline 362149109463301 & Rough Rock & 10R-111 \\
\hline 363005110250901 & Peabody 2 & -- \\
\hline 362406110563201 & White Mesa Arch & $1 \mathrm{~K}-214$ \\
\hline 362823109463101 & Rough Rock & 10R-119 \\
\hline 362936109564101 & BM observation well 1 & $8 \mathrm{~T}-537$ \\
\hline 363013109584901 & Sweetwater Mesa & $8 \mathrm{~K}-443$ \\
\hline 363103109445201 & Rough Rock & 9Y-95 \\
\hline 363130110254501 & Peabody 8 & --- \\
\hline 363143110355001 & BM observation well 4 & $2 \mathrm{~T}-514$ \\
\hline 363213110342001 & Shonto Southeast & $2 \mathrm{~K}-301$ \\
\hline 363232109465601 & Rough Rock & 9Y-92 \\
\hline 363309110420501 & Shonto & $2 \mathrm{~K}-300$ \\
\hline 363423110305501 & Shonto Southeast & $2 \mathrm{~T}-502$ \\
\hline 363727110274501 & Long House Valley & $8 \mathrm{~T}-510$ \\
\hline 363850110100801 & BM observation well 2 & $8 \mathrm{~T}-538$ \\
\hline 364226110171701 & Kayenta West & $8 \mathrm{~T}-541$ \\
\hline 364248109514601 & Northeast Rough Rock & $8 \mathrm{~A}-180$ \\
\hline 364338110154601 & BM observation well 3 & $8 \mathrm{~T}-500$ \\
\hline 364034110240001 & Marsh Pass & $8 \mathrm{~T}-522$ \\
\hline
\end{tabular}


Table 3. Withdrawals from the $\mathrm{N}$ aquifer by well system, Black Mesa area, northeastern Arizona, calendar year 2007.

[Withdrawals, in acre-feet, are from flowmeter measurements. BIA, Bureau of Indian Affairs; NTUA, Navajo Tribal Utility Authority; USGS, U.S. Geological Survey; Peabody, Peabody Western Coal Company; Hopi, Hopi Village Administrations]

\begin{tabular}{|c|c|c|c|c|}
\hline \multirow[b]{2}{*}{$\begin{array}{c}\text { Well System } \\
\text { (one or more wells) }\end{array}$} & \multirow[b]{2}{*}{ Owner } & \multirow[b]{2}{*}{ Source of data } & \multicolumn{2}{|c|}{ Withdrawals } \\
\hline & & & $\begin{array}{l}\text { Confined } \\
\text { aquifer }\end{array}$ & $\begin{array}{l}\text { Unconfined } \\
\text { aquifer }\end{array}$ \\
\hline Chilchinbito & BIA & USGS/BIA & 2.3 & \\
\hline Dennehotso & BIA & USGS/BIA & & 13.9 \\
\hline Hopi High School & BIA & USGS/BIA & 23.8 & \\
\hline Hotevilla & BIA & USGS/BIA & 13.4 & \\
\hline Kayenta & BIA & USGS/BIA & 49.4 & \\
\hline Keams Canyon & BIA & USGS/BIA & ${ }^{1} 61.9$ & \\
\hline Low Mountain & BIA & USGS/BIA & ${ }^{2} 0$ & \\
\hline Piñon & BIA & USGS/BIA & ${ }^{2} 0$ & \\
\hline Red Lake & BIA & USGS/BIA & & 92.7 \\
\hline Rocky Ridge & BIA & USGS/BIA & 7.8 & \\
\hline Rough Rock & BIA & USGS/BIA & 25.0 & \\
\hline Second Mesa & BIA & USGS/BIA & 3.3 & \\
\hline Shonto & BIA & USGS/BIA & & 124.5 \\
\hline Tuba City & BIA & USGS/BIA & & 113.6 \\
\hline Chilchinbito & NTUA & USGS/NTUA & 36.9 & \\
\hline Dennehotso & NTUA & USGS/NTUA & & 47.4 \\
\hline Forest Lake & NTUA & USGS/NTUA & 10.5 & \\
\hline Hard Rock & NTUA & USGS/NTUA & 44.0 & \\
\hline Kayenta & NTUA & USGS/NTUA & 490.3 & \\
\hline Kits'iili & NTUA & USGS/NTUA & 17.8 & \\
\hline Piñon & NTUA & USGS/NTUA & 306.4 & \\
\hline Red Lake & NTUA & USGS/NTUA & & 62.7 \\
\hline Rough Rock & NTUA & USGS/NTUA & 33.8 & \\
\hline Shonto & NTUA & USGS/NTUA & & 21.8 \\
\hline Shonto Junction & NTUA & USGS/NTUA & & 81.7 \\
\hline Tuba City & NTUA & USGS/NTUA & & 959.8 \\
\hline Mine Well Field & Peabody & Peabody & 1,172 & \\
\hline Bacavi & Hopi & USGS/Hopi & 25.3 & \\
\hline Hopi Civic Center & Hopi & USGS/Hopi & 3.6 & \\
\hline Hopi Cultural Center & Hopi & USGS/Hopi & 6.6 & \\
\hline Kykotsmovi & Hopi & USGS/Hopi & 63.9 & \\
\hline Mishongnovi & Hopi & USGS/Hopi & 4.7 & \\
\hline Moenkopi & Hopi & USGS/Hopi & & 124.8 \\
\hline Polacca & Hopi & USGS/Hopi & 179.7 & \\
\hline Shipaulovi & Hopi & USGS/Hopi & 18.5 & \\
\hline Shungopovi & Hopi & USGS/Hopi & 32.6 & \\
\hline
\end{tabular}

\footnotetext{
${ }^{1}$ Meters broken in 2007, withdrawal estimated from well operator

${ }^{2}$ Well taken out of service
} 
Table 4. Total, industrial, and municipal withdrawals from the N aquifer for discrete time periods during 1965 to 2007 , Black Mesa area, northeastern Arizona.

\begin{tabular}{lccccc}
\hline Period & $\begin{array}{c}\text { Total withdrawals } \\
\text { (acre-feet) }\end{array}$ & $\begin{array}{c}\text { Industrial } \\
\text { withdrawals } \\
\text { (acre-feet) }\end{array}$ & $\begin{array}{c}\text { Municipal } \\
\text { withdrawals } \\
\text { (acre-feet) }\end{array}$ & $\begin{array}{c}\text { Percent } \\
\text { industrial }\end{array}$ & $\begin{array}{c}\text { Percent } \\
\text { municipal }\end{array}$ \\
\hline $1965-2007$ & 226,670 & 140,470 & 86,200 & 62 & 38 \\
$1965-1972$ & 8,930 & 6,460 & 2,470 & 72 & 28 \\
$1973-1984$ & 66,470 & 46,540 & 19,930 & 70 & 30 \\
1985 & 4,720 & 2,520 & 2,200 & 53 & 47 \\
$1986-2005$ & 138,180 & 82,580 & 55,600 & 60 & 40 \\
2005 & 7,330 & 4,480 & 2,850 & 61 & 39 \\
12006 & 4,100 & 1,200 & 2,900 & 29 & 71 \\
2007 & 4,270 & 1,170 & 3,100 & 27 & 73 \\
\hline
\end{tabular}

${ }^{1}$ Municipal withdrawals for NTUA wells was estimated and consequently total withdrawals, percent industrial, and percent municipal were calculated using estimated value.

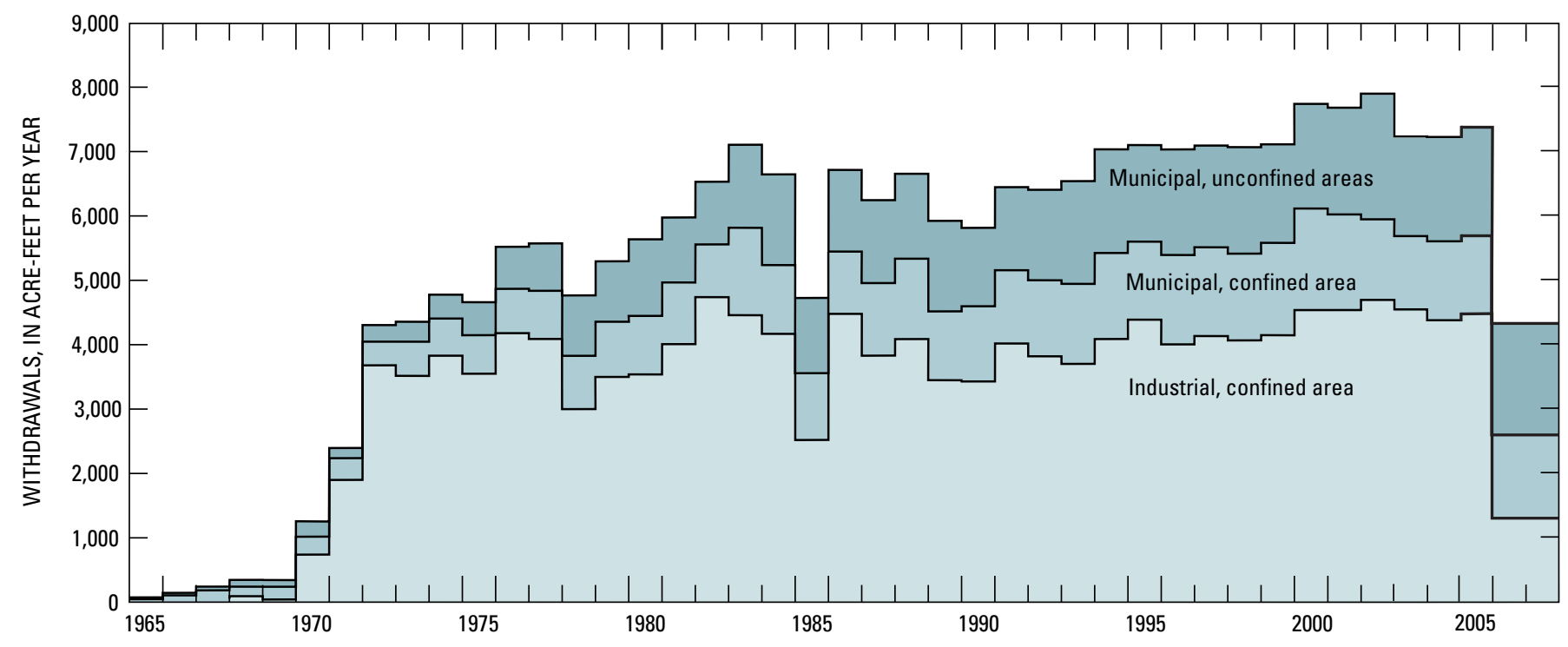

Figure 3. Annual withdrawals from N aquifer, Black Mesa area, northeastern Arizona, 1965-2007.

\section{Groundwater Levels in the N Aquifer}

Groundwater is monitored in the $\mathrm{N}$ aquifer to determine the effects that withdrawals have on the potentiometric surface of the aquifer. Groundwater in the $\mathrm{N}$ aquifer is under confined conditions in the central part of the study area and under unconfined or water-table conditions around the periphery (fig. 4). From the recharge areas near Shonto, groundwater moves radially to the southwest toward Tuba City, to the south toward the Hopi Reservation, and to the east toward Rough Rock and Dennehotso (Eychaner, 1983).

Groundwater levels are measured once a year at the same time of year to limit the effect of seasonal variation.
Groundwater levels are compared with levels from previous years to determine short-term changes and also compared to prestress water levels to determine long-term changes. Only water levels from municipal and stock wells that were not considered to have been recently pumped, influenced by nearby pumping, or blocked or obstructed are compared. During February 2008 to March 2008, water levels in 33 of 34 wells having annual measurements met these criteria (table 5). Of the 34 wells, 6 are continuous-recording observation wells, and water levels were measured by steel or electric tape in these 6 wells four times between June 2007 and June 2008. Twentynine of 33 water levels measured in 2008 were compared with water levels for the same wells measured in 2007. Water levels 
measured in 2008 in five of the wells, Goldtooth 3A-28, Shonto 2K-301, Tuba City NTUA 1, Tuba City NTUA 3, and Tuba City NTUA 4, could not be compared to 2007 water levels because measurements are not available for these wells in 2007.

The wells used for water-level measurements are distributed throughout the study area (fig. 5). The wells were constructed between 1934 and 1993, the total well depths range from $107 \mathrm{ft}$ near Dennehotso (8A-180) to 3,636 ft near $\mathrm{PWCC}$, and depths to the top of the $\mathrm{N}$ aquifer range from $0 \mathrm{ft}$ near Tuba City to 2,617 ft near PWCC (table 6).

From 2007 to 2008, water levels decreased in 15 of the 29 wells for which comparisons could be made (table 5). The median water-level change in the 29 wells was $-0.2 \mathrm{ft}$ (table 7). From 2007 to 2008, water levels declined in 6 of the 11 wells measured in the unconfined parts of the aquifer (table 5). The median water-level change was $-0.2 \mathrm{ft}$ (table 7 ). Water-level changes in the unconfined part of the aquifer ranged from -4.2 $\mathrm{ft}$ at Rough Rock 9Y-95 to $+0.5 \mathrm{ft}$ at Tuba City Rare Metals (table 5). In the confined area, water levels declined in 9 of 18 wells measured from 2007 to 2008 . The median water-level change was $-0.2 \mathrm{ft}$ (table 7). Water-level changes in the confined part of the aquifer ranged from $-3.3 \mathrm{ft}$ at Kitsillie NTUA 2 to $+6.6 \mathrm{ft}$ at Kykotsmovi PM3 (table 5).

From the prestress period (before 1965) to 2008, the median water-level change in 33 wells was $-12.9 \mathrm{ft}$ (table 7). Water levels in 15 unconfined wells had a median change of $-1.0 \mathrm{ft}$. Water-level changes in the unconfined part of the aquifer ranged from $-33.1 \mathrm{ft}$ at $8 \mathrm{~T}-510$ near Long House Valley to $+11.8 \mathrm{ft}$ at 9 Y-95 in Rough Rock (fig. 5 and table 5). Water levels in 18 wells in the confined part of the aquifer had a median change of -33.2 ft (table 7). Water-level changes in the confined part of the aquifer ranged from $-198.7 \mathrm{ft}$ at Keams Canyon PM2 to $+13.4 \mathrm{ft}$ at $3 \mathrm{~K}-311$ (fig. 5 and table 5).

Hydrographs of groundwater levels in the network of wells observed annually show the time trends of changes since the 1950s, 1960s, or 1970s (fig. 6). In most of the unconfined area, water levels have changed only slightly (generally less than 10 feet). Near Long House Valley, however, the water level in well 8T-510 has declined about $33 \mathrm{ft}$ (fig. 5 and fig. 6). Water levels have declined in most of the confined area; however, the magnitudes of declines are varied. Larger declines have occurred near the municipal pumping centers (wells Piñon PM6, Keams Canyon PM2) and near the wells for PWCC (BM6). Smaller declines occurred away from pumping centers in or near towns in the study area (wells 10T-258, 8K-443, 10R-111, 8T-522; fig. 5).

Hydrographs for the Black Mesa continuous-record observation wells show continuous water-levels since the early 1970s (fig. 7). Water levels in the two wells in the unconfined areas (BM1 and BM4) have had small seasonal or year-to-year variation since 1972. Water levels in wells BM2, BM3, and BM5 in the confined area have consistently declined since the early to mid 1960s (fig. 7). Water levels in BM6 in the confined area had consistently declined since the mid 70's until the year 2007, when a distinct change occurred in the trend of the water level from decreasing to increasing.

\section{Spring Discharge from the N Aquifer}

The effect of withdrawals from the $\mathrm{N}$ aquifer on the water quality and quantity of springs around Black Mesa is a concern. Groundwater in the $\mathrm{N}$ aquifer discharges from many springs around the margins of Black Mesa, and changes to the discharge from those springs could indicate effects of withdrawals from the N aquifer. In 2008, Moenkopi School Spring and Pasture Canyon Spring, two of the four springs that have been measured annually, were measured for discharge, Moenkopi School Spring is in the western part of the Black Mesa area and is also referred to as Susunova Spring by the Hopi Tribe (fig. 8). Discharge from Moenkopi School Spring was measured in June 2008 by the volumetric method and compared to discharge data from previous years to determine changes over time (fig. 9). The trend from discharge measurements at this spring is not corrected for seasonal variability. In 2008 , the measured discharge was $8.3 \mathrm{gal} / \mathrm{min}$ from Moenkopi School Spring (table 8). From 2007 to 2008, discharge decreased by 7.7 percent; for the period of record, discharge measurements have fluctuated and exhibit a decreasing trend $(\mathrm{p}<0.01)$ (fig. 9 and table 8 ).

Pasture Canyon Spring is also located in the western part of the study area and issues from the Navajo Sandstone and alluvium (fig. 8). Discharge of Pasture Canyon Spring is measured at two locations. The first is where the spring issues from the Navajo Sandstone, which is also the water-quality sampling point, and the second is farther down-canyon at the USGS gaging station. The USGS gaging station at Pasture Canyon measures the discharge from Pasture Canyon Spring and the additional discharge from seeps along Pasture Canyon. Discharge was measured at Pasture Canyon Spring in June 2008 by the volumetric method, and when compared to previous years a decreasing trend $(p<0.01)$ is seen (fig. 9 and table $8)$. The trend from discharge measurements at this spring are not corrected for seasonal variability. In 2008 the measured discharge was $29.4 \mathrm{gal} / \mathrm{min}$, which is an 11.7 percent decrease from 2005, the last time Pasture Canyon Spring was measured. Pasture Canyon Spring was not measured in 2006 or 2007 because of budgetary restraints.

\section{Surface-Water Discharge}

Continuous surface-water discharge data have been collected at selected streams since the monitoring program began in 1971. Surface-water discharge in the study area generally originates as groundwater that discharges to streams and as surface runoff from rainfall or snowmelt. Groundwater discharges to some channel reaches at a fairly constant rate throughout the year; however, the amount of groundwater discharge that results in surface flow is affected by seasonal fluctuations in evapotranspiration (Thomas, 2002a). In contrast, the amount of rainfall or snowmelt runoff varies widely throughout the year. In the winter and spring, the amount and timing of snowmelt runoff are a result of the temporal 


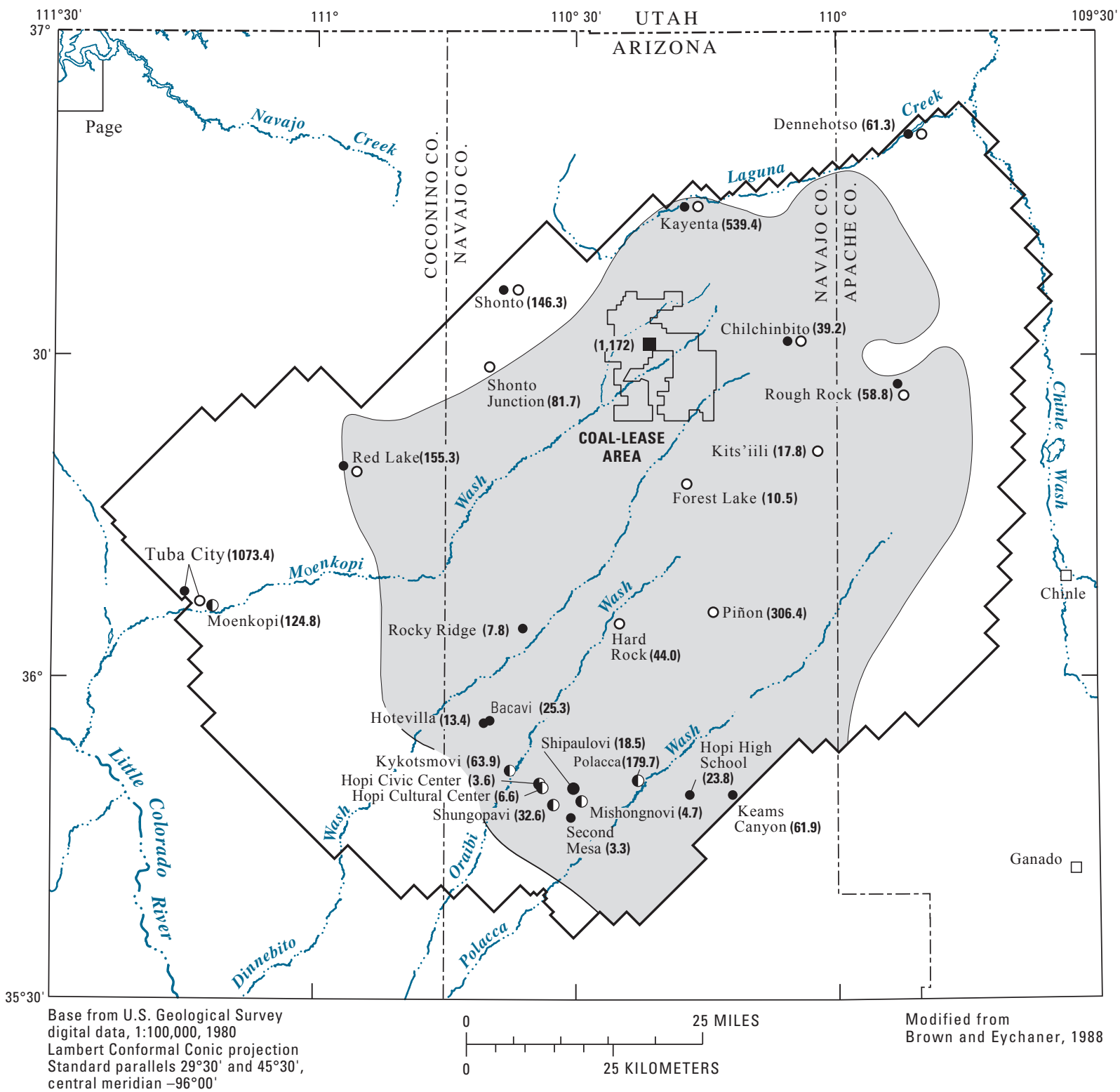

EXPLANATION

CONFINED AND UNCONFINED CONDITIONS IN THE N AQUIFER WITHIN MODEL BOUNDARY

Confined

Unconfined

APPROXIMATE BOUNDARY BETWEEN CONFINED AND UNCONFINED CONDITIONS -

From Brown and Eychaner (1988)

- BOUNDARY OF MATHEMATICAL

MODEL-From Brown and

Eychaner (1988)
WELL-SYSTEM OWNER

- Bureau of Indian Affairs

- Navajo Tribal Utility Authority

- Hopi Tribe

- Peabody Western Coal Company
Piñon (306.4) WITHDRAWALS FROM THE N AQUIFER - Piñon, well-system name; 306.4, total withdrawal in acre-feet for 2007. The total is cumulative at locations served by multiple wells

Figure 4. Locations of well systems monitored for annual withdrawals from the $\mathrm{N}$ aquifer, Black Mesa area, northeastern Arizona, calendar year 2007. 
Table 5. Water-level changes in monitoring program wells completed in the $\mathrm{N}$ aquifer, Black Mesa area, northeastern Arizona, prestress period to 2008 (calendar year).

[Dashes indicate no data. Do., ditto; R, reported from driller's log]

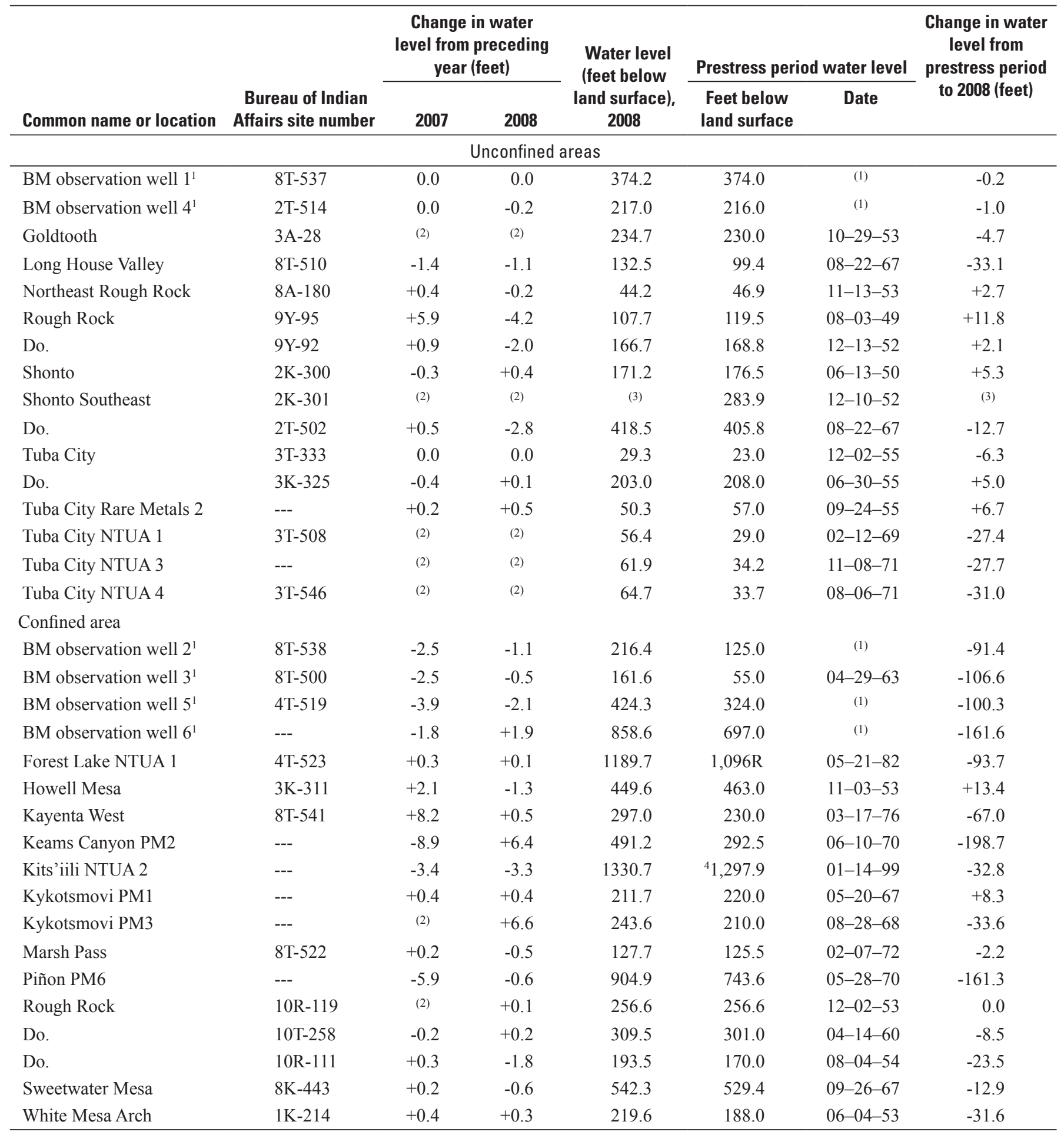

${ }^{1}$ Continuous recorder. Prestress water levels were estimated from a groundwater model, except for well BM3 (Brown and Eychaner, 1988).

${ }^{2} \mathrm{Can}$ not be determined because at least one of the water-level measurements is not available.

${ }^{3}$ Water level not measured because of obstruction in well.

${ }^{4}$ Water level is the first water level measured after completion of well. 


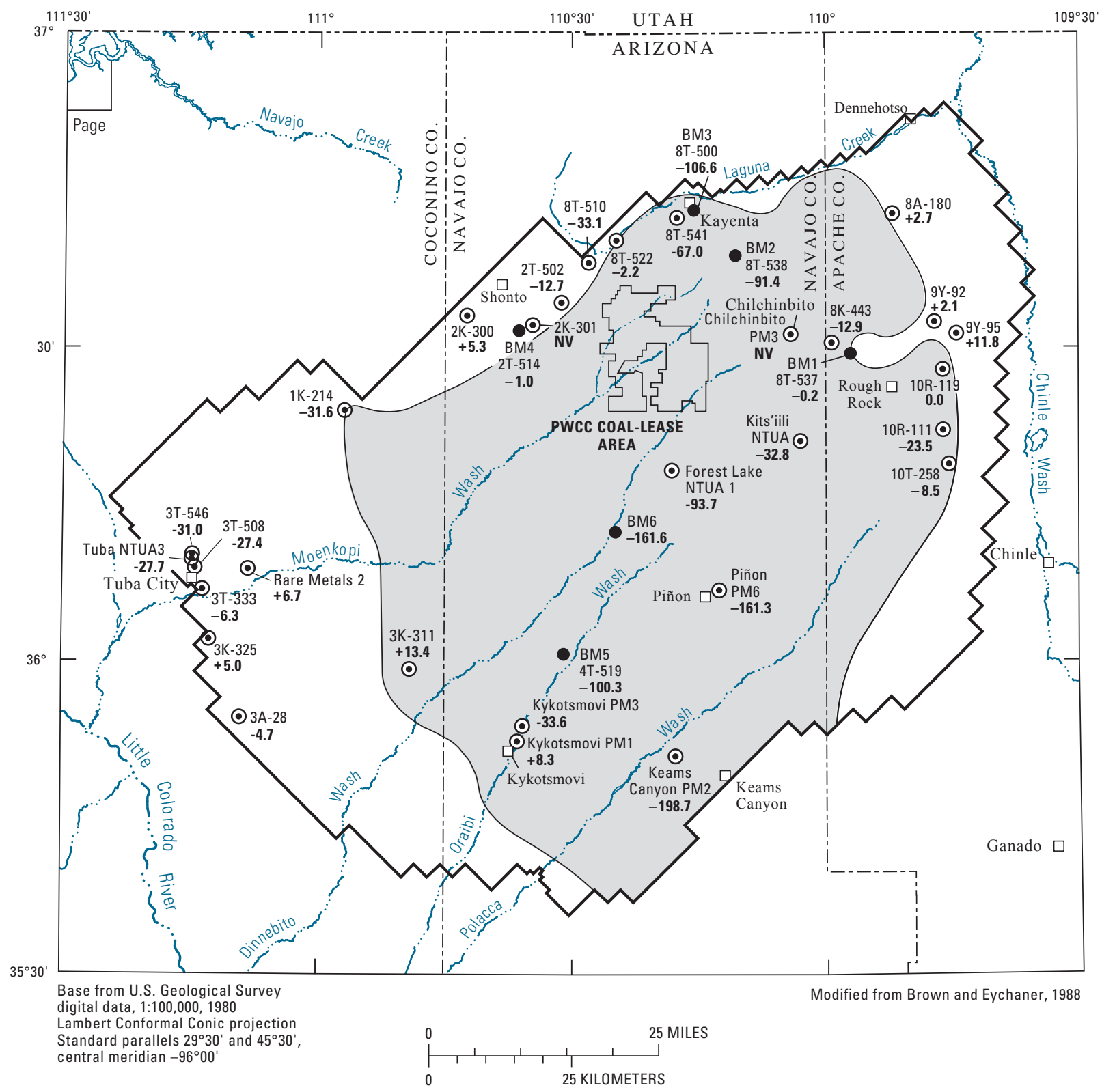

CONFINED AND UNCONFINED

CONDITIONS IN THE N AQUIFER Confined area within the boundary
of the mathmatical boundary

Unconfined area within the boundary of the mathematcal boundary

APPROXIMATE BOUNDARY BETWEEN CONFINED AND UNCONFINED CONDITIONS From Brown and Eychaner (1988)

- BOUNDARY OF MATHEMATICAL MODEL-From Brown and Eychaner (1988)

\section{EXPLANATION}

○ WELL IN WHICH DEPTH TO 2K-300 WATER WAS MEASURED
$+\mathbf{5 . 3}$ $2 \mathrm{~K}-300$, is Bureau of Indian Affairs site number; second entry, $\mathbf{+ 5 . 3}$, is change in water level, in feet, between measurement made during the prestress period and measurement made during 2008. NV, site not visited
CONTINUOUS WATER-LEVEL RECORDING SITE (OBSERVATION WELL) MAINTAINED

BY THE U.S. GEOLOGICAL SURVEY - First entry, BM2, is U.S. Geological Survey well number; second entry, $8 \mathrm{~T}-538$, is Bureau of Indian Affairs site number; third entry, $\mathbf{- 9 1 . 4}$, is change in water level, in feet, from simulated prestress period to 2008

Figure 5. Water-level changes in N-aquifer wells from the prestress period (prior to 1965) to 2008, Black Mesa area, northeastern Arizona. 
Table 6. Well-construction characteristics, depth to top of $\mathrm{N}$ aquifer, and type of data collected for wells in monitoring program, Black Mesa area, northeastern Arizona, 2007-8.

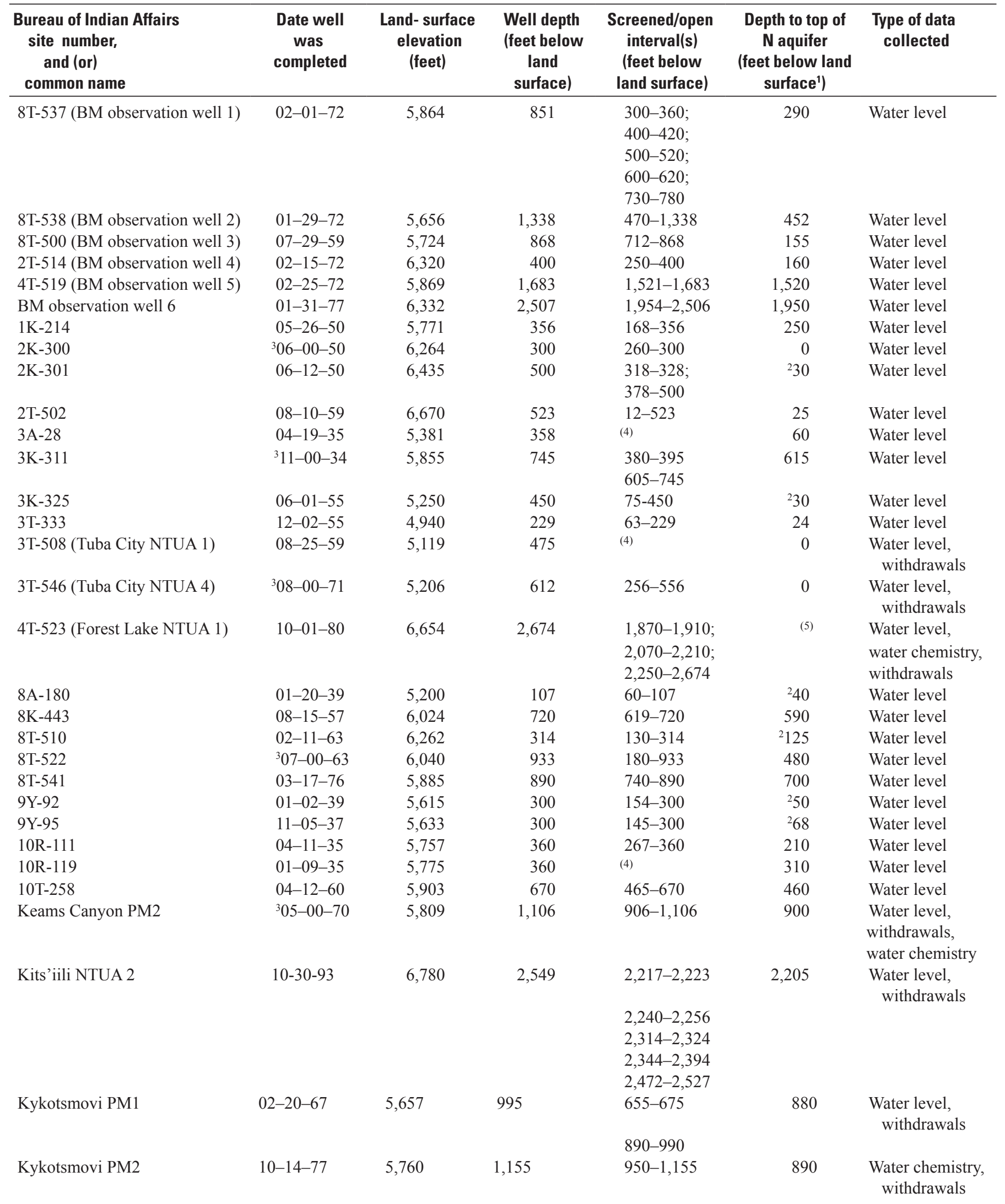


Table 6. Well-construction characteristics, depth to top of $\mathrm{N}$ aquifer, and type of data collected for wells in monitoring program, Black Mesa area, northeastern Arizona, 2007-8.-Continued

\begin{tabular}{|c|c|c|c|c|c|c|}
\hline $\begin{array}{l}\text { Bureau of Indian Affairs } \\
\text { site number, } \\
\text { and (or) } \\
\text { common name } \\
\end{array}$ & $\begin{array}{l}\text { Date well } \\
\text { was } \\
\text { com- } \\
\text { pleted } \\
\end{array}$ & $\begin{array}{l}\text { Land- surface } \\
\text { elevation } \\
\text { (feet) }\end{array}$ & $\begin{array}{l}\text { Well depth } \\
\text { (feet below } \\
\text { land } \\
\text { surface) }\end{array}$ & $\begin{array}{c}\text { Screened/open } \\
\text { interval(s) } \\
\text { (feet below } \\
\text { land surface) }\end{array}$ & $\begin{array}{l}\text { Depth to top of } \\
\mathrm{N} \text { aquifer } \\
\text { (feet below land } \\
\text { surface') }\end{array}$ & $\begin{array}{c}\text { Type of data } \\
\text { collected }\end{array}$ \\
\hline Kykotsmovi PM3 & $08-07-68$ & 5,618 & 1,220 & $850-1,220$ & 840 & $\begin{array}{l}\text { Water level, } \\
\text { withdrawals }\end{array}$ \\
\hline Low Mountain PM2 & ${ }^{3} 04-00-72$ & 6,123 & 1,343 & $1,181-1,262$ & 1,153 & Water level \\
\hline Peabody 2 & ${ }^{3} 06-00-1967$ & 6,530 & 3,636 & $1,816-3,603$ & 728 & $\begin{array}{l}\text { Water chemistry, } \\
\text { withdrawals }\end{array}$ \\
\hline Peabody 8 & 07-01-1980 & 6,675 & 3,418 & $2,460-3,180$ & 2,617 & $\begin{array}{c}\text { Water chemistry, } \\
\text { withdrawals }\end{array}$ \\
\hline Piñon NTUA 1 & $02-25-80$ & 6,336 & 2,350 & $1,860-2,350$ & 1,850 & $\begin{array}{l}\text { Water chemistry, } \\
\text { withdrawals }\end{array}$ \\
\hline Piñon PM6 & ${ }^{3} 02-00-70$ & 6,397 & 2,248 & $1,895-2,243$ & 1,870 & $\begin{array}{l}\text { Water level, } \\
\text { withdrawals }\end{array}$ \\
\hline Tuba City NTUA 3 & ${ }^{3} 10-00-71$ & 5,176 & 442 & $142-442$ & 34 & $\begin{array}{l}\text { Water level, } \\
\text { withdrawals }\end{array}$ \\
\hline Tuba City Rare Metals 2 & ${ }^{3} 09-00-55$ & 5,108 & 705 & $100-705$ & 255 & Water level \\
\hline
\end{tabular}

${ }^{1}$ Depth to top of $\mathrm{N}$ aquifer from Eychaner (1983) and Brown and Eychaner (1988).

${ }^{2}$ All material between land surface and top of the $\mathrm{N}$ aquifer is unconsolidated-soil, alluvium, or dune sand.

${ }^{3} 00$, indicates month or day is unknown.

${ }^{4}$ Screened and (or) open intervals are unknown.

${ }^{5}$ Depth to top of $\mathrm{N}$ aquifer was not estimated.

Table 7. Median changes in water levels in monitoring-program wells, 2007-8 and prestress period (prior to 1965) to 2008, N aquifer, Black Mesa area,northeastern Arizona.

\begin{tabular}{llcc}
\hline Years & Aquifer conditions & Number of wells & $\begin{array}{c}\text { Median change in } \\
\text { water level (feet) }\end{array}$ \\
\hline $2007-08$ & All & 29 & -0.2 \\
& Unconfined & 11 & -0.2 \\
& Confined & 18 & -0.2 \\
Prestress-2008 & All & 33 & -12.9 \\
& Unconfined & 15 & -1.0 \\
& Confined & 18 & -33.2 \\
\hline
\end{tabular}


UNCONFINED AREA

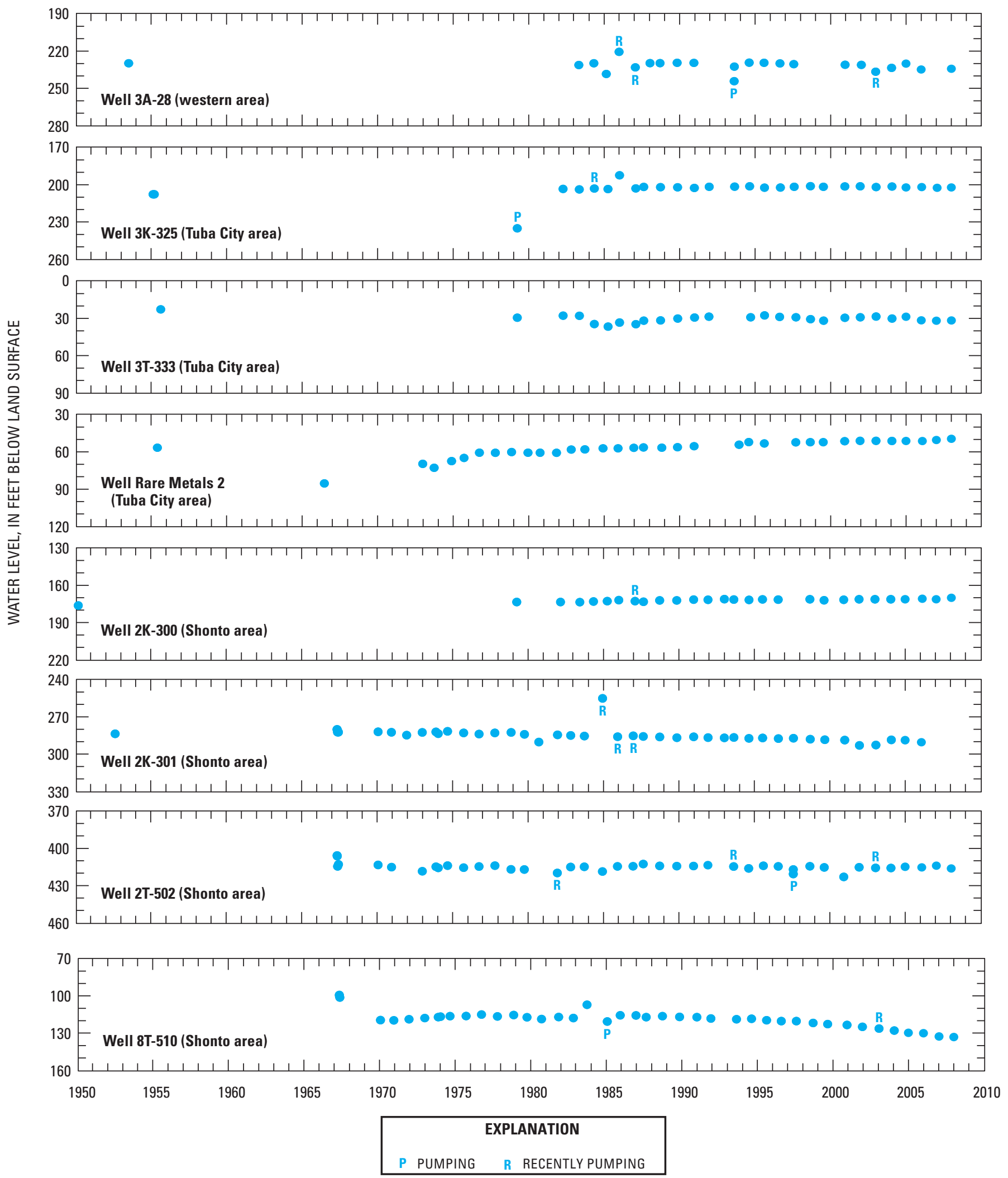

Figure 6. Observed water levels (1950-2008) in annual observation-well network, N aquifer, Black Mesa area, northeastern Arizona. 
(UNCONFINED AREA)
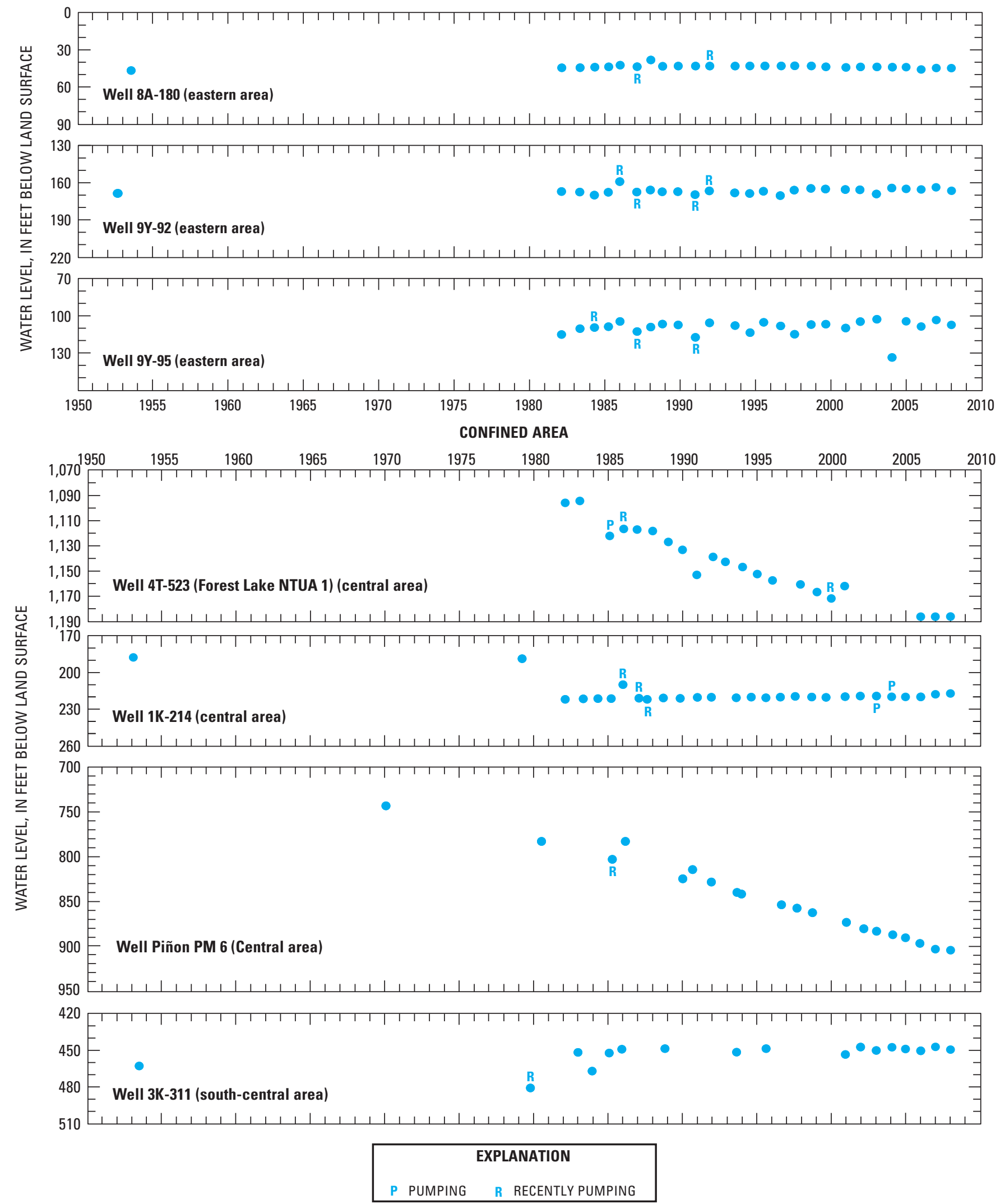

Figure 6. Continued 
(CONFINED AREA)
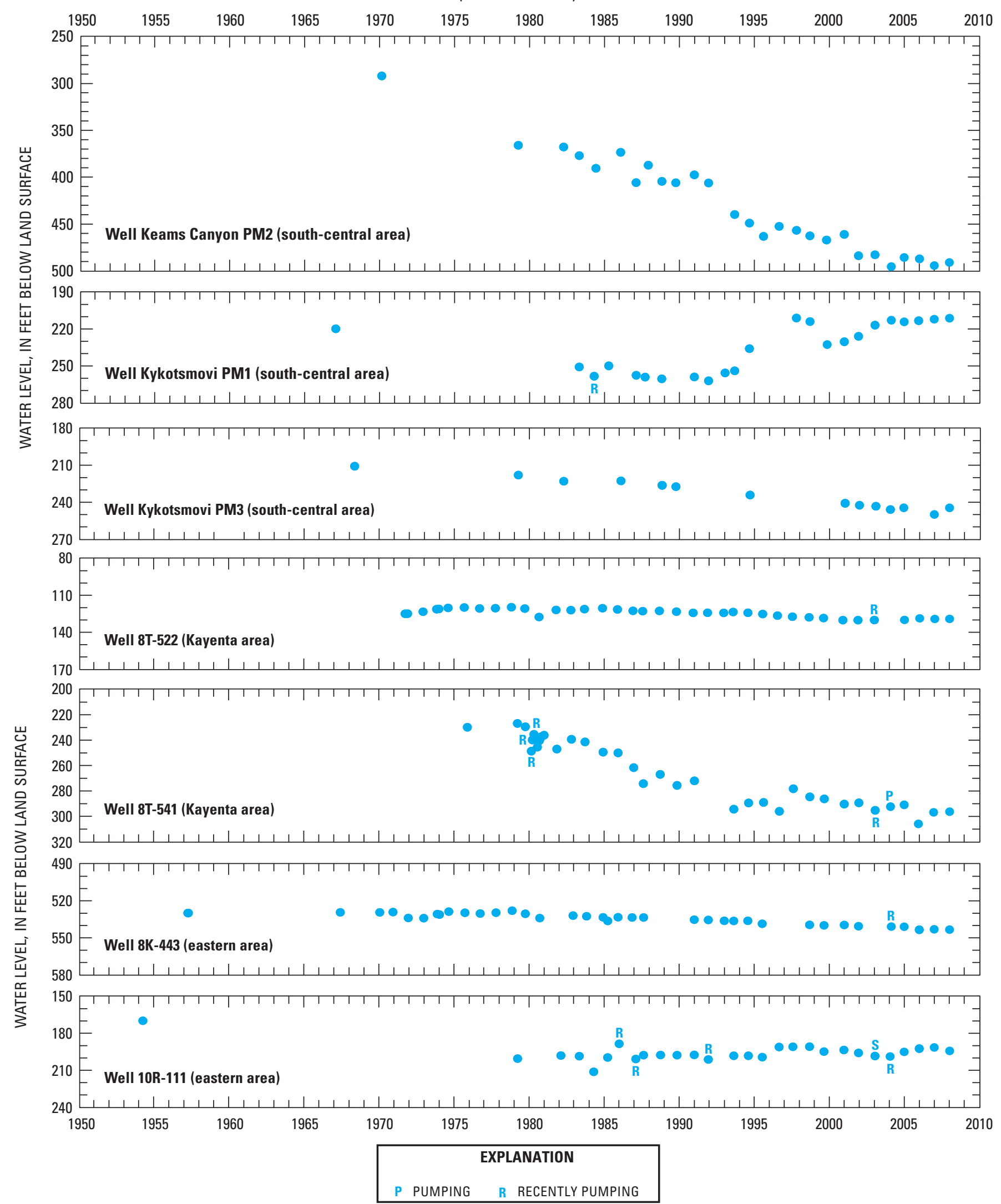

Figure 6. Continued 
(CONFINED AREA)

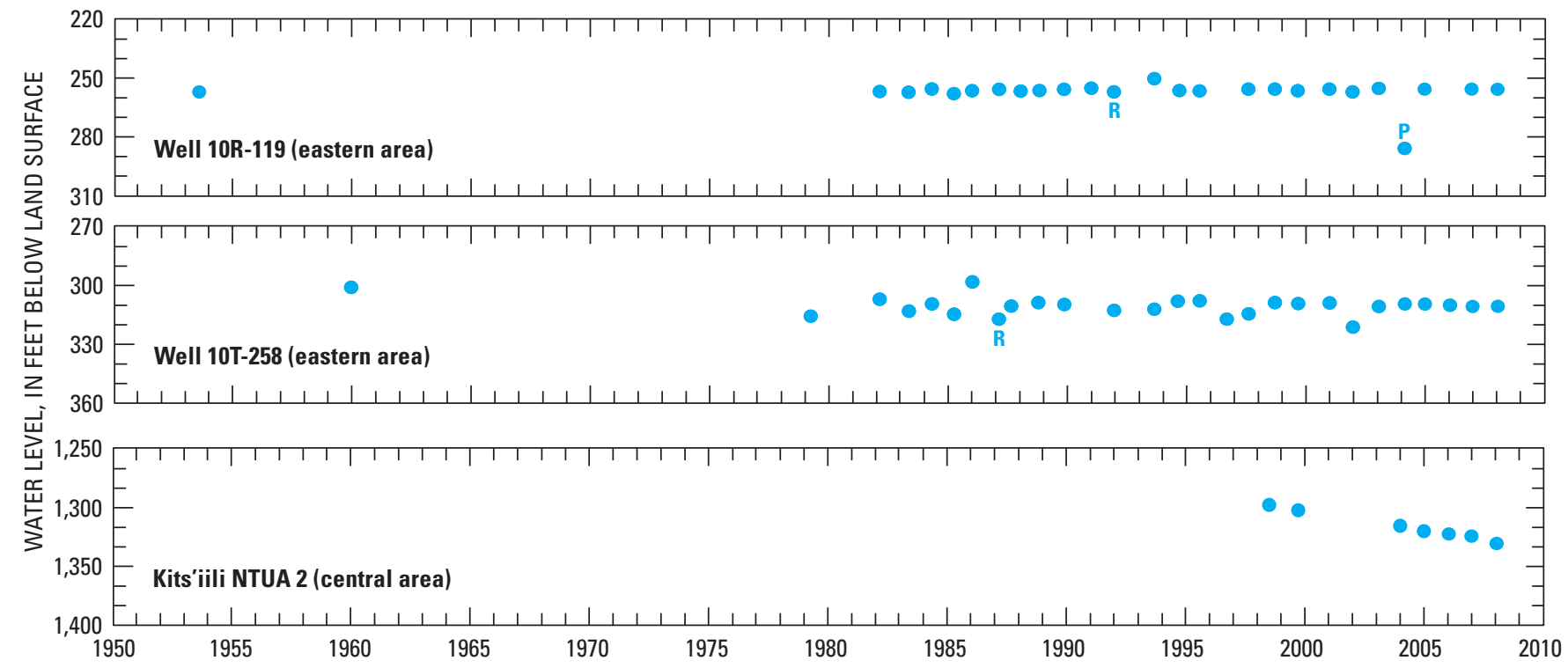

EXPLANATION

P PUMPING R RECENTLY PUMPING

Figure 6. Continued 


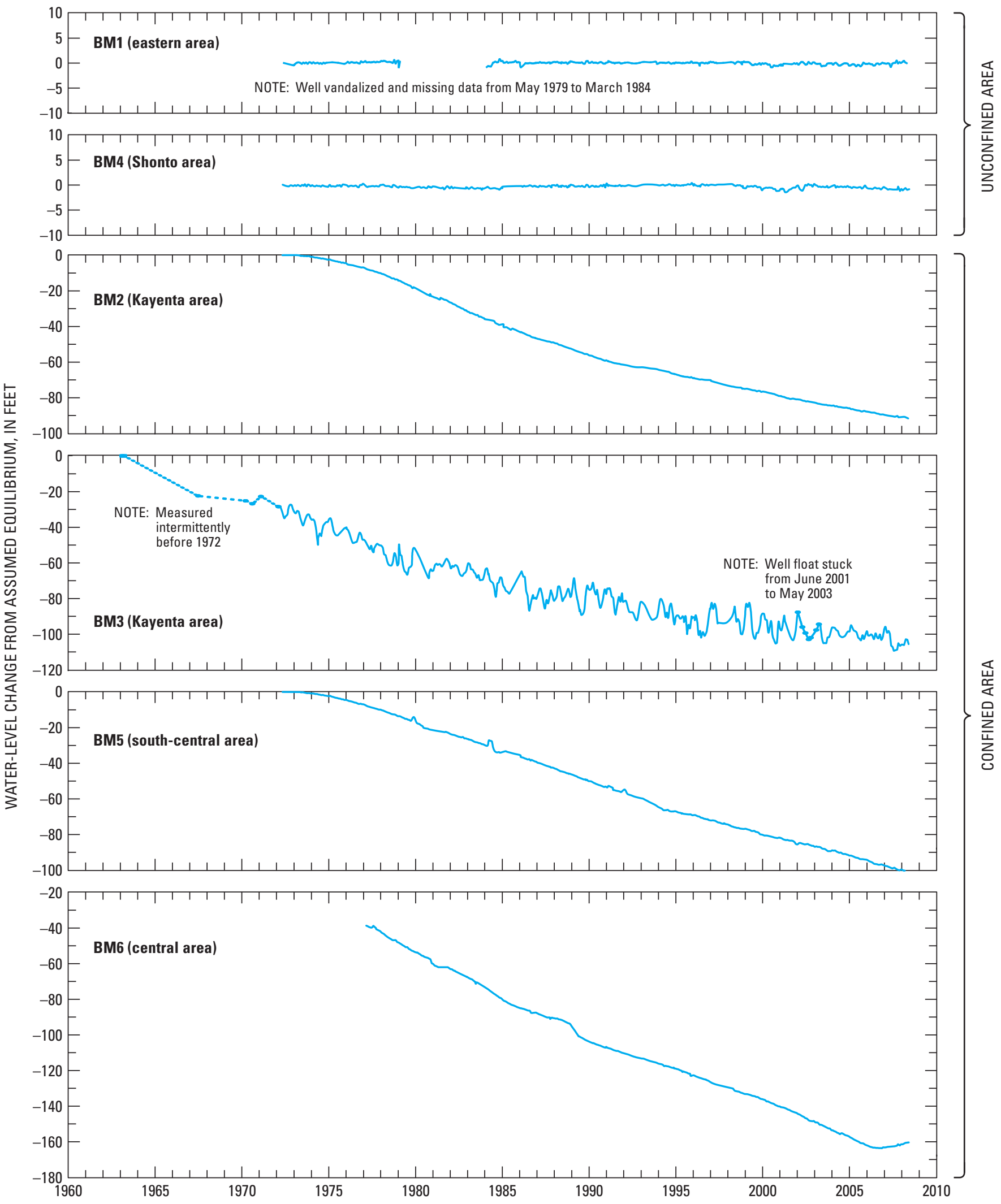

Figure 7. Observed water-level changes in continuous-record observation wells, BM1-BM6, 1963-2008, N aquifer, Black Mesa area, northeastern Arizona. 


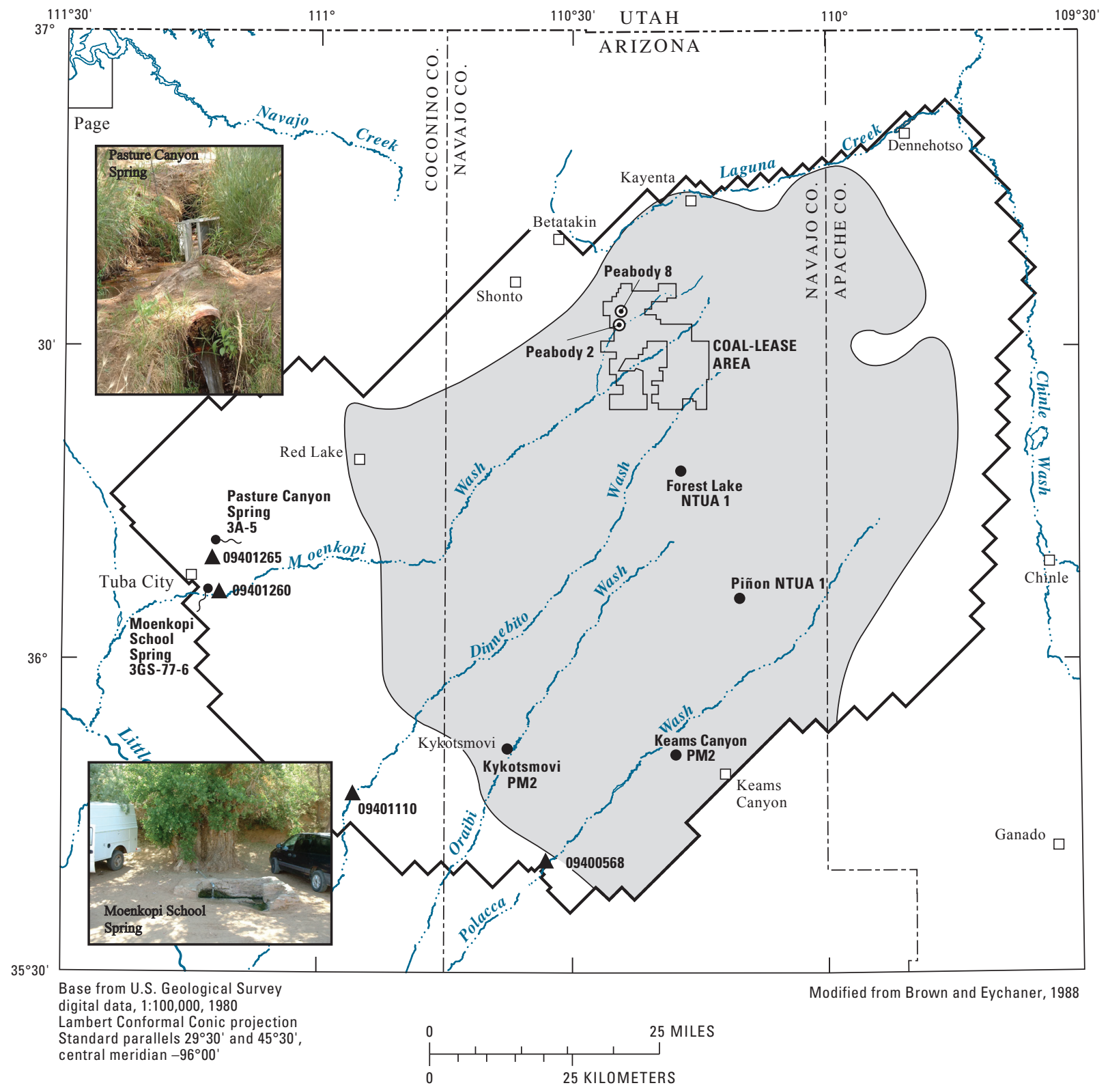

EXPLANATION

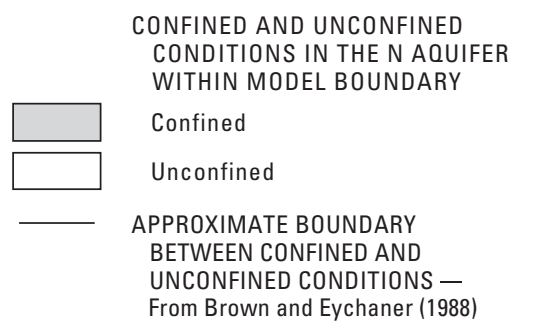

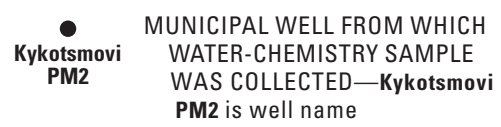

INDUSTIAL WELL FROM WHICH

Peabody 8 WATER-CHEMISTRY SAMPLE

WAS COLLECTED-Peabody 8 is a well number

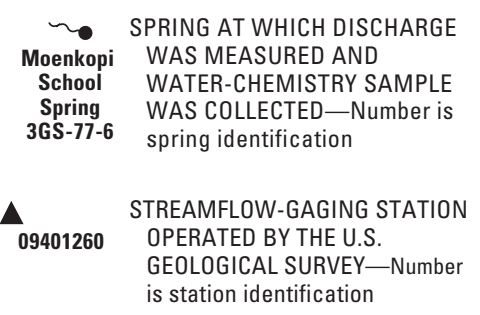

BOUNDARY OF MATHEMATICAL

MODEL-From Brown and

Eychaner (1988)

Figure 8. Surface-water and water-chemistry data-collection sites, N aquifer, Black Mesa area, northeastern Arizona, 2007-8. 
A. Discharge data for Moenkopi School Spring, 1987-2008.

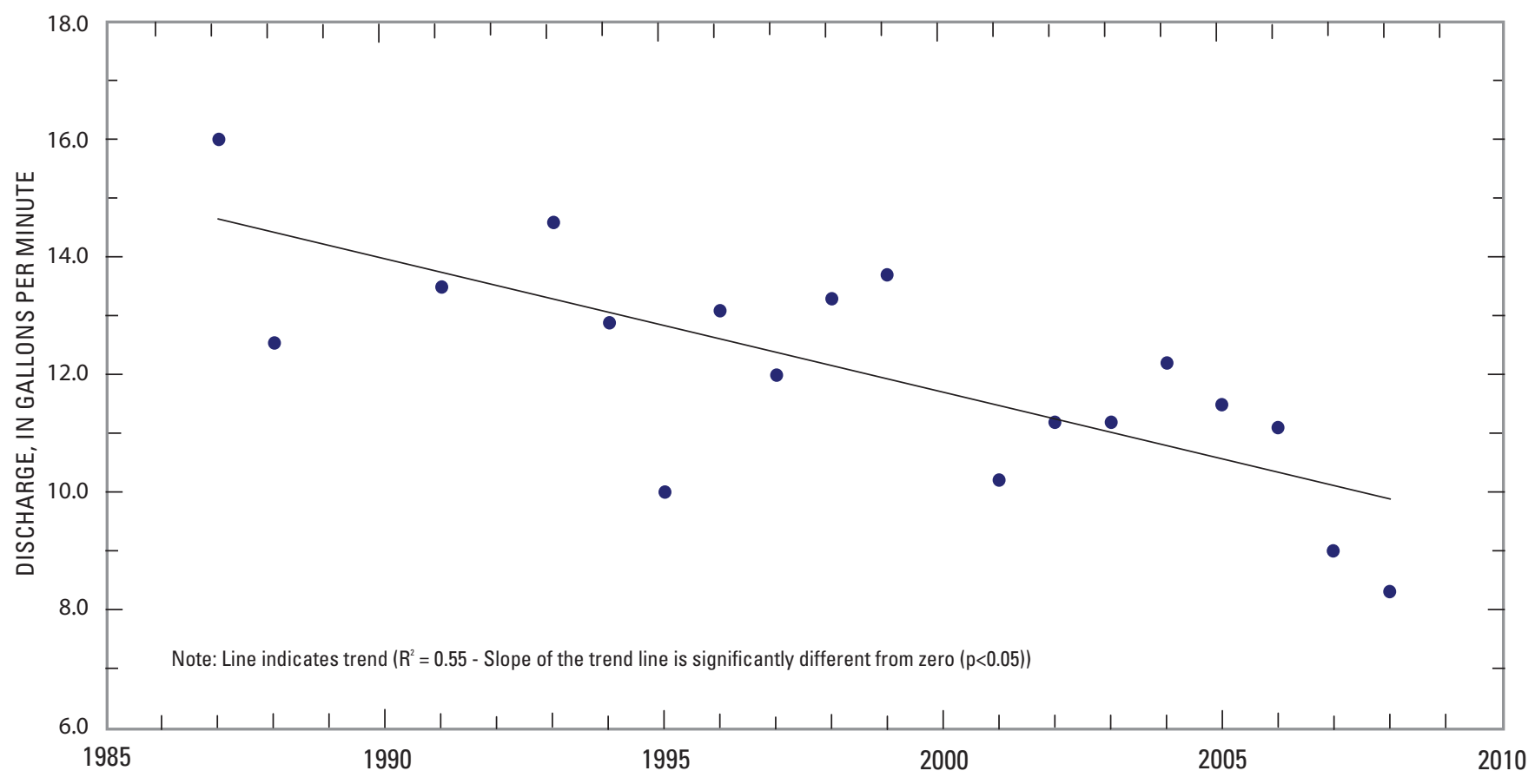

B. Discharge data for Pasture Canyon Spring, 1994-2008.

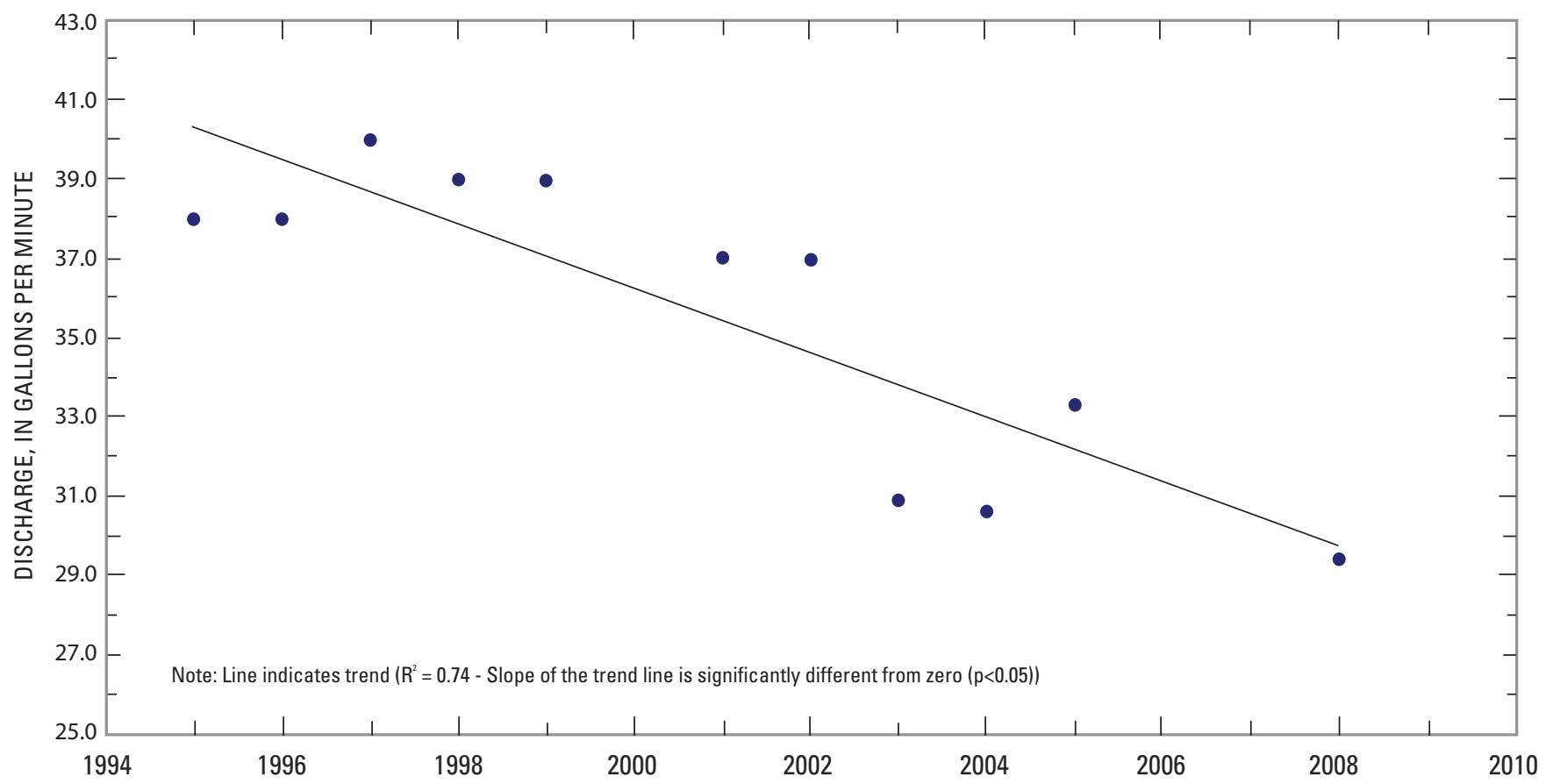

Figure 9. Discharge from Moenkopi School Spring $(A)$ and Pasture Canyon Spring $(B)$, N Aquifer, northeastern Black Mesa area, northeastern Arizona, 1987-2008. Data from 1952 meaasurement at Moenkopi School Spring is not shown because it is from a different measuring location. Data from 1988 to 1993 measurements at Pasture Canyon Spring are not shown because they are from a different measuring location. Linear trend lines were generated using method of least squares. 
Table 8. Discharge measurements for Moenkopi School Spring and Pasture Canyon Spring, Black Mesa area, northeastern Arizona, 1952-2008.

[Measured discharges do not represent the total discharge from the springs]

\begin{tabular}{|c|c|c|c|}
\hline $\begin{array}{c}\text { Bureau of Indian Affairs } \\
\text { site Number }\end{array}$ & Rock formation(s) & Date of measurement & $\begin{array}{c}\text { Discharge, in } \\
\text { gallons per minute }\end{array}$ \\
\hline \multicolumn{4}{|c|}{ Moenkopi School Spring' } \\
\hline \multirow[t]{19}{*}{$3 \mathrm{GS}-77-6$} & Navajo Sandstone $^{2}$ & $05-16-52$ & 40.0 \\
\hline & & $04-22-87$ & ${ }^{3} 16.0$ \\
\hline & & $11-29-88$ & ${ }^{3} 12.5$ \\
\hline & & $02-21-91$ & ${ }^{3} 13.5$ \\
\hline & & 04-07-93 & ${ }^{3} 14.6$ \\
\hline & & $12-07-94$ & ${ }^{3} 12.9$ \\
\hline & & $12-04-95$ & ${ }^{3} 10.0$ \\
\hline & & $12-16-96$ & ${ }^{3} 13.1$ \\
\hline & & $12-17-97$ & ${ }^{3} 12.0$ \\
\hline & & $12-08-98$ & ${ }^{3} 13.3$ \\
\hline & & $12-13-99$ & ${ }^{3} 13.7$ \\
\hline & & $03-12-01$ & ${ }^{3} 10.2$ \\
\hline & & 06-19-02 & ${ }^{3} 11.2$ \\
\hline & & $05-01-03$ & ${ }^{3} 11.2$ \\
\hline & & 03-29-04 & ${ }^{3} 12.2$ \\
\hline & & 04-04-05 & ${ }^{3} 11.5$ \\
\hline & & $03-13-06$ & ${ }^{3} 11.1$ \\
\hline & & $05-31-07$ & 39.0 \\
\hline & & 06-03-08 & ${ }^{3} 8.3$ \\
\hline \multicolumn{4}{|c|}{ Pasture Canyon Spring ${ }^{1}$} \\
\hline \multirow[t]{15}{*}{$3 \mathrm{~A}-5$} & Navajo Sandstone, alluvium & & \\
\hline & & $11-18-88$ & ${ }^{4} 211$ \\
\hline & & $03-24-92$ & ${ }^{4} 233$ \\
\hline & & $10-12-93$ & ${ }^{4} 211$ \\
\hline & & $12-04-95$ & 538.0 \\
\hline & & $12-16-96$ & ${ }^{5} 38.0$ \\
\hline & & $12-17-97$ & 540.0 \\
\hline & & $12-10-98$ & 539.0 \\
\hline & & $12-21-99$ & 539.0 \\
\hline & & $06-12-01$ & 537.0 \\
\hline & & 04-04-02 & 537.0 \\
\hline & & $05-01-03$ & ${ }^{5} 30.9$ \\
\hline & & $04-26-04$ & 530.6 \\
\hline & & $04-27-05$ & 533.3 \\
\hline & & 06-03-08 & 529.4 \\
\hline
\end{tabular}

${ }^{1}$ Volumetric discharge measurement.

${ }^{2}$ Interfingering with the Kayenta Formation at this site.

${ }^{3}$ Discharge measured at water-quality sampling site and at a different point than the measurement in 1952 .

${ }^{4}$ Discharge measured in an irrigation ditch about 0.25 mile below water-quality sampling point.

${ }^{5}$ Discharge measured at water-quality sampling point about 20 feet below upper spring on west side of canyon. 
variation in snow accumulation, air temperatures, and rate of snowmelt. Although rainfall can occur throughout the year, most rainfall runoff occurs during the summer months. The amount and timing of rainfall runoff depend on the intensity and duration of thunderstorms during the summer and cyclonic storms during the fall, winter, and spring.

In 2007, discharge data were collected at four continuous-recording streamflow-gaging stations (tables 9-12). Data collection at these stations began in July 1976 (Moenkopi Wash at Moenkopi, 09401260), June 1993 (Dinnebito Wash near Sand Springs, 09401110), April 1994 (Polacca Wash near Second Mesa, 09400568), and August 2004 (Pasture Canyon Spring, 09401265; table 13). The annual average discharges at the four streamflow-gaging stations vary during the periods of record (fig. 10A), and no trends are apparent for Moenkopi Wash, Polacca Wash, and Dinnebito Wash. No trends can be determined for Pasture Canyon Wash either, because the length of record is insufficient to determine a trend.

Precipitation is another variable to consider when evaluating for trends in annual discharge. Higher precipitation would generally lead to greater annual discharge at a streamflow-gaging station. The average annual precipitation measured at Navajo National Monument (Betatakin; fig. 1) from 1976 to 2007 is 12.6 in. (fig. 10B). Annual precipitation at Betatakin has been mostly less than that average from 1995 through 2002 (11.4 in.); precipitation data was incomplete for 2003, above average for calendar year 2004 and 2005 (17.4 in.), and below the average for calendar years 2006 (11.24 in.) and 2007 (8.26 in.; fig. 8B).

Trends in the groundwater discharge component of total flow at the three streamflow-gaging stations were evaluated on the basis of the median flow for 120 consecutive daily mean flows for four winter months (November, December, January, and February) as a surrogate measure for base flow (fig. 11). Groundwater discharge was assumed to be constant throughout the year, and the median winter flow was assumed to represent the constant annual groundwater discharge. Most flow that occurs during the winter is groundwater discharge; rainfall and snowmelt runoff are infrequent. Most of the precipitation in the winter falls as snow, and the cold temperatures prevent appreciable snowmelt. Evapotranspiration is at a minimum during the winter. Rather than the average flow, the median flow for November, December, January, and February is used to estimate groundwater discharge because the median is less affected by occasional winter runoff. Nonetheless, the median flow for November, December, January, and February is an index of groundwater discharge rather than an absolute estimate of groundwater discharge. A more rigorous and accurate estimate would involve detailed evaluations of streamflow hydrographs, flows into and out of bank storage, gain and loss of streamflow as it moves down the stream channel, and interaction of groundwater in the $\mathrm{N}$ aquifer with groundwater in the shallow alluvial aquifers in the stream valleys. The median winter flow, however, is useful as a consistent index for evaluating possible time trends in groundwater discharge.
Median winter flows calculated for the 2008 water year were $2.7 \mathrm{ft}^{3} / \mathrm{s}$ for Moenkopi Wash at Moenkopi, $0.51 \mathrm{ft}^{3} / \mathrm{s}$ for Dinnebito Wash near Sand Springs, and $0.33 \mathrm{ft}^{3} / \mathrm{s}$ for Polacca Wash near Second Mesa (fig. 11A-C). For the period of record at each streamflow-gaging station, the median winter flows have generally remained constant, as indicated by trends calculated using the method of least squares ( $p>0.05$ )(fig. 11A-C).

\section{Water Chemistry}

Water samples for water-chemistry analyses are collected each year from selected wells and springs as part of the Black Mesa monitoring program. Field measurements are made, and water samples are analyzed for major ions, nutrients, iron, boron, and arsenic. Water-chemistry samples have been collected from 12 wells; 8 of the wells have been sampled every year, and the other 4 wells have been selected on the basis of a sampling rotation. In 2008 the well-sampling sites were reduced. A sample was collected at six sites: Keams canyon PM2, Kykotsmovi PM2, Piñon NTUA 1, Forest Lake NTUA 1, Peabody 2, and Peabody 8. Since 1989, samples have been collected from the same four springs (Moenkopi School Spring, Pasture Canyon Spring, Unnamed spring near Dennehotso, and Burro Spring); however, in 2008, samples were collected from only two of these-Moenkopi School Spring and Pasture Canyon Spring. Long-term data for specific conductance, total dissolved solids, chloride, and sulfate for the wells and springs sampled each year are shown in the reports published each year. These constituents are monitored on an annual basis because increased concentrations in the $\mathrm{N}$ aquifer could indicate leakage from the overlying D aquifer. On average, the concentrations of dissolved solids in water from the $\mathrm{D}$ aquifer is about 7 times greater than that of water from the $\mathrm{N}$ aquifer, concentration of chloride ions is about 11 times greater, and concentrations of sulfate ions is about 30 times greater (Eychaner, 1983). Historical data for other constituents for all the wells and springs in the Black Mesa study area are available from the USGS water-quality database (http://waterdata.usgs.gov/az/nwis/qw), or they can be found in the past monitoring reports cited in the Previous Investigations section of this report.

\section{Water-Chemistry Data for Wells Completed in the N Aquifer}

The primary types of water in the $\mathrm{N}$ aquifer in the Black Mesa study area are calcium bicarbonate water and sodium bicarbonate water. Calcium bicarbonate water generally is in the recharge and unconfined areas of the northern and northwestern parts of the Black Mesa study area, and sodium bicarbonate water is generally in the area that is confined and downgradient to the south and east (Lopes and Hoffmann, 1997). In 2008, water 
Table 9. Discharge data (daily mean values), Moenkopi Wash at Moenkopi, Arizona (09401260), calendar year 2007.

[e, estimated; CFSM, cubic feet per square mile; dashes indicate no data]

DISCHARGE, IN CUBIC FEET PER SECOND, CALENDAR YEAR 2007 DAILY MEAN VALUES

\begin{tabular}{|c|c|c|c|c|c|c|c|c|c|c|c|c|}
\hline DAY & JAN & FEB & MAR & APR & MAY & JUN & JUL & AUG & SEP & ОСт & NOV & DEC \\
\hline 1 & e 3.5 & e2. 5 & e2. 5 & 2.3 & 2.5 & e 0.21 & 0.00 & 78 & 0.00 & e0. 35 & 0.71 & 51 \\
\hline 2 & e 4.4 & e2. 4 & e2. 6 & 2.3 & 3.3 & 0.04 & 0.00 & 517 & 0.00 & e0. 66 & 0.71 & 48 \\
\hline 3 & e5.1 & e2. 3 & e2. 7 & 2.2 & 2.0 & 0.01 & 0.00 & 150 & 0.00 & e1.2 & 0.74 & 12 \\
\hline 4 & e 4.8 & e2. 2 & e2.7 & 2.2 & 1.7 & 0.00 & 0.00 & 128 & 4.0 & e0.70 & 0.76 & 4.2 \\
\hline 5 & e 4.6 & $\mathrm{e} 2.2$ & 2.8 & 2.1 & 1.6 & 0.00 & 0.00 & 211 & 10 & e 0.27 & 0.80 & 3.0 \\
\hline 6 & e 4.5 & e2. 3 & 2.8 & 2.1 & 1.7 & 0.00 & 0.00 & 480 & 0.55 & 0.01 & 0.84 & 2.6 \\
\hline 7 & e 4.4 & e2. 5 & 2.9 & 2.1 & 1.4 & 0.00 & 0.00 & 80 & 0.57 & 0.00 & 0.84 & 2.5 \\
\hline 8 & e 4.3 & 2.6 & 3.2 & 2.1 & 1.2 & 0.00 & 0.00 & e30 & 0.00 & 0.00 & 0.86 & 2.1 \\
\hline 9 & e 4.2 & 2.7 & 3.2 & 2.3 & 1.3 & 0.00 & 0.00 & e15 & 0.00 & 0.06 & 0.97 & 1.9 \\
\hline 10 & e 4.1 & e2. 5 & 3.1 & 2.1 & 1.2 & 0.00 & 0.00 & e10 & 0.00 & 0.17 & 1.1 & 2.4 \\
\hline 11 & e 4.0 & e2. 3 & 2.9 & 1.8 & 1.2 & 0.00 & 0.00 & 7.4 & 0.00 & 0.20 & 1.1 & 2.9 \\
\hline 12 & e3. 9 & e2. 3 & 2.8 & 2.0 & 1.1 & 0.00 & 0.00 & 2.7 & 0.00 & 0.19 & 1.1 & 2.5 \\
\hline 13 & e3. 8 & e2. 3 & 2.8 & 2.4 & 0.85 & 0.00 & 0.00 & 0.28 & 0.00 & 0.15 & 1.1 & 2.2 \\
\hline 14 & e3. 8 & e2. 3 & 2.8 & 2.0 & 0.79 & 0.00 & 0.00 & 135 & 0.00 & 0.25 & 1.2 & $\mathrm{e} 2.2$ \\
\hline 15 & e3.7 & e2. 3 & 2.7 & 1.7 & 0.67 & 0.00 & 0.00 & 227 & 0.00 & 0.29 & 1.2 & $\mathrm{e} 2.2$ \\
\hline 16 & e3. 6 & e2. 2 & 2.6 & 1.7 & 0.70 & 0.00 & 0.00 & 172 & 0.00 & 0.34 & 1.2 & $\mathrm{e} 2.2$ \\
\hline 17 & e3. 4 & 2.4 & 2.7 & 1.9 & 0.71 & 0.00 & 0.00 & 68 & 0.00 & 0.35 & 1.3 & e2. 2 \\
\hline 18 & e3. 3 & 2.3 & 2.8 & 1.7 & 0.69 & 0.00 & 0.00 & 15 & 0.00 & 0.35 & 1.4 & e2. 2 \\
\hline 19 & e3. 3 & 2.4 & 2.7 & 1.7 & 0.51 & 0.00 & 0.00 & 4.7 & 0.00 & 0.36 & 1.4 & e2. 2 \\
\hline 20 & e3. 3 & 2.6 & 2.4 & 1.8 & 0.67 & 0.00 & 0.00 & 1.8 & 0.00 & 0.32 & 1.4 & e2. 2 \\
\hline 21 & e3. 2 & 2.5 & 2.6 & 2.0 & 0.47 & 0.00 & 0.00 & 0.50 & 0.00 & 0.30 & 1.4 & 2.4 \\
\hline 22 & e3.1 & 2.3 & 2.7 & 2.0 & 0.29 & 0.00 & 0.00 & 0.00 & 0.00 & 0.34 & 1.3 & 2.0 \\
\hline 23 & e3. 0 & 2.2 & 3.1 & 3.3 & 32 & 0.00 & e118 & 0.00 & 63 & 0.34 & 1.4 & 1.5 \\
\hline 24 & e3. 0 & 2.5 & 3.5 & 4.0 & 5.5 & 0.00 & e 328 & 0.00 & 93 & 0.45 & 1.4 & 2.6 \\
\hline 25 & e2. 9 & 2.4 & 3.3 & 3.1 & 1.2 & 0.00 & 9.9 & 0.00 & 14 & 0.54 & 1.6 & 2.7 \\
\hline 26 & e2. 9 & 2.2 & 2.9 & 2.3 & e0.50 & 0.00 & e25 & 0.00 & 1.3 & 0.60 & 2.0 & 2.5 \\
\hline 27 & e2.9 & 2.2 & 2.7 & 2.6 & e 0.40 & 0.00 & 52 & 0.00 & e 0.70 & 0.65 & 1.7 & 2.9 \\
\hline 28 & e2. 8 & $\mathrm{e} 2.4$ & 2.6 & 1.8 & e0. 35 & 0.00 & 369 & 0.00 & e0.50 & 0.61 & 1.5 & 2.8 \\
\hline 29 & e2. 8 & --- & 2.6 & 2.4 & e 0.30 & 0.00 & 535 & 0.00 & e 0.30 & 0.59 & 1.6 & 3.1 \\
\hline 30 & e2.7 & --- & 2.5 & 2.6 & e0. 30 & 0.00 & 400 & 0.00 & e0.30 & 0.64 & 1.8 & 3.3 \\
\hline 31 & $\mathrm{e} 2.6$ & --- & 2.3 & --- & e 0.25 & --- & 40 & 0.00 & --- & 0.67 & --- & 3.3 \\
\hline TOTAL & 111.9 & 66.3 & 86.5 & 66.6 & 67.35 & 0.26 & 1876.90 & 2333.38 & 188.22 & 11.95 & 36.43 & 181.8 \\
\hline MEAN & 3.61 & 2.37 & 2.79 & 2.22 & 2.17 & 0.01 & 60.5 & 75.3 & 6.27 & 0.39 & 1.21 & 5.86 \\
\hline MAX & 5.1 & 2.7 & 3.5 & 4.0 & 32 & 0.21 & 535 & 517 & 93 & 1.2 & 2.0 & 51 \\
\hline MIN & 2.6 & 2.2 & 2.3 & 1.7 & 0.25 & 0.00 & 0.00 & 0.00 & 0.00 & 0.00 & 0.71 & 1.5 \\
\hline MED & 3.5 & 2.3 & 2.7 & 2.1 & 0.85 & 0.00 & 0.00 & 7.4 & 0.00 & 0.34 & 1.2 & 2.5 \\
\hline $\mathrm{AC}-\mathrm{FT}$ & 222 & 132 & 172 & 132 & 134 & 0.5 & 3720 & 4630 & 373 & 24 & 72 & 361 \\
\hline CFSM & 0.00 & 0.00 & 0.00 & 0.00 & 0.00 & 0.00 & 0.04 & 0.05 & 0.00 & 0.00 & 0.00 & 0.00 \\
\hline \multicolumn{2}{|c|}{ Calendar year 2007} & \multicolumn{2}{|l|}{ Total 5,027.6 } & \multicolumn{2}{|l|}{ mean 13.8} & Max 535 & Min 0.00 & Median 1.8 & \multicolumn{2}{|c|}{ Acre-ft 9,970 } & \multicolumn{2}{|c|}{ CFSM 0.008} \\
\hline
\end{tabular}


Table 10. Discharge data (daily mean values), Dinnebito Wash near Sand Springs, Arizona (09401110), calendar year 2007. [e, estimated; CFSM, cubic feet per square mile; dashes indicate no data]

DISCHARGE, IN CUBIC FEET PER SECOND, CALENDAR YEAR 2007DAILY MEAN VALUES

\begin{tabular}{|c|c|c|c|c|c|c|c|c|c|c|c|c|}
\hline DAY & JAN & FEB & MAR & APR & MAY & JUN & JUL & AUG & SEP & ОСт & NOV & $\mathrm{DEC}$ \\
\hline 1 & 0.45 & 0.54 & 0.39 & 0.37 & 0.34 & 0.20 & 0.14 & 20 & 3.8 & e 0.22 & 0.28 & 1.4 \\
\hline 2 & 0.44 & 0.44 & 0.40 & 0.35 & 0.44 & 0.21 & 0.14 & 62 & 15 & e0. 20 & 0.28 & 25 \\
\hline 3 & 0.44 & 0.43 & 0.38 & 0.35 & 0.30 & 0.21 & 0.11 & 163 & 1.4 & e0.18 & 0.27 & 9.5 \\
\hline 4 & 0.44 & 0.45 & 0.40 & 0.37 & 0.28 & 0.19 & 0.14 & 197 & 21 & 0.20 & 0.29 & 2.6 \\
\hline 5 & 0.49 & 0.46 & 0.42 & 0.37 & 0.34 & 0.18 & 0.13 & 292 & 13 & 0.18 & 0.30 & 0.87 \\
\hline 6 & 0.37 & 0.47 & 0.42 & 0.37 & 0.33 & 0.15 & 0.12 & 336 & 15 & 0.16 & 0.30 & 0.62 \\
\hline 7 & 0.39 & 0.49 & 0.44 & 0.35 & 0.32 & 0.18 & 0.13 & 13 & 2.8 & 0.17 & 0.30 & 0.59 \\
\hline 8 & 0.40 & 0.48 & 0.47 & 0.35 & 0.31 & 0.19 & 0.12 & 1.7 & 0.25 & 0.18 & 0.30 & 0.61 \\
\hline 9 & 0.41 & 0.49 & 0.42 & 0.37 & 0.31 & 0.19 & 0.12 & 0.38 & 0.18 & 0.19 & 0.31 & 0.56 \\
\hline 10 & 0.45 & 0.53 & 0.41 & 0.32 & 0.30 & 0.18 & 0.11 & 0.32 & 0.16 & 0.19 & 0.31 & 1.3 \\
\hline 11 & 0.45 & 0.60 & 0.38 & 0.34 & 0.29 & 0.20 & 0.10 & 0.30 & 0.16 & 0.18 & 0.31 & 1.3 \\
\hline 12 & 0.43 & 0.54 & 0.40 & 0.37 & 0.28 & 0.23 & 0.13 & 0.28 & 0.16 & 0.18 & 0.37 & 0.57 \\
\hline 13 & 0.40 & 0.51 & 0.41 & 0.35 & 0.27 & 0.19 & 0.13 & 0.24 & 0.16 & 0.18 & 0.33 & 0.63 \\
\hline 14 & 0.34 & 0.86 & 0.40 & 0.33 & 0.26 & 0.18 & 0.13 & 0.23 & 0.15 & 0.19 & 0.33 & 0.56 \\
\hline 15 & 0.30 & 0.44 & 0.40 & 0.33 & 0.26 & 0.17 & 0.12 & 154 & 0.16 & 0.21 & 0.34 & 0.41 \\
\hline 16 & 0.31 & 0.35 & 0.39 & 0.33 & 0.27 & 0.16 & 0.12 & 21 & 0.16 & 0.23 & 0.35 & 0.48 \\
\hline 17 & 0.30 & 0.34 & 0.40 & 0.34 & 0.27 & 0.15 & 0.12 & 14 & 0.16 & 0.20 & 0.34 & 0.56 \\
\hline 18 & 0.31 & 0.35 & 0.38 & 0.31 & 0.27 & 0.15 & 0.12 & 6.6 & 0.15 & 0.18 & 0.33 & 0.61 \\
\hline 19 & 0.31 & 0.40 & 0.39 & 0.31 & 0.26 & 0.15 & 0.12 & 1.8 & 0.15 & 0.21 & 0.34 & 0.65 \\
\hline 20 & 0.43 & 0.37 & 0.41 & 0.34 & 0.26 & 0.15 & 0.12 & 0.52 & 0.15 & 0.23 & 0.33 & 0.63 \\
\hline 21 & 0.45 & 0.34 & 0.37 & 0.35 & 0.24 & 0.15 & 0.09 & 0.42 & 0.15 & 0.21 & 0.32 & e0.58 \\
\hline 22 & 0.43 & 0.33 & 0.45 & 0.33 & 0.24 & 0.15 & 0.09 & 0.23 & 0.18 & 0.21 & 0.31 & 0.46 \\
\hline 23 & 0.42 & 1.3 & 0.71 & 0.38 & 0.45 & 0.15 & 0.10 & 0.15 & 0.41 & 0.24 & 0.32 & 0.48 \\
\hline 24 & 0.41 & 0.44 & 0.47 & 0.38 & 0.29 & 0.15 & 0.09 & 0.15 & 150 & 0.25 & 0.31 & 0.52 \\
\hline 25 & 0.43 & 0.43 & 0.44 & 0.34 & 0.26 & 0.14 & 0.08 & 0.12 & 18 & 0.26 & 0.32 & 0.51 \\
\hline 26 & 0.43 & 0.44 & 0.42 & 0.36 & 0.25 & 0.15 & 21 & 0.12 & 6.4 & 0.27 & 0.34 & 0.44 \\
\hline 27 & 0.44 & 0.41 & 0.37 & 0.34 & 0.24 & 0.14 & 25 & 0.13 & 0.50 & 0.27 & 0.33 & 0.49 \\
\hline 28 & 0.44 & 0.39 & 0.28 & 0.32 & 0.23 & 0.14 & 194 & 0.13 & 0.31 & 0.28 & 0.34 & 0.39 \\
\hline 29 & 0.48 & --- & 0.44 & 0.36 & 0.21 & 0.14 & 14 & 0.14 & 0.25 & 0.28 & 0.33 & 0.43 \\
\hline 30 & 0.55 & --- & 0.39 & 0.33 & 0.21 & 0.14 & 99 & 0.17 & 0.22 & 0.27 & 0.56 & 0.46 \\
\hline 31 & 0.72 & --- & 0.37 & --- & 0.21 & --- & 66 & 0.17 & --- & 0.27 & --- & 0.47 \\
\hline TOTAL & 13.06 & 13.62 & 12.82 & 10.41 & 8.79 & 5.06 & 421.92 & 1286.30 & 250.57 & 6.67 & 9.79 & 54.68 \\
\hline MEAN & 0.42 & 0.49 & 0.41 & 0.35 & 0.28 & 0.17 & 13.6 & 41.5 & 8. 35 & 0.22 & 0.33 & 1.76 \\
\hline MAX & 0.72 & 1.3 & 0.71 & 0.38 & 0.45 & 0.23 & 194 & 336 & 150 & 0.28 & 0.56 & 25 \\
\hline MIN & 0.30 & 0.33 & 0.28 & 0.31 & 0.21 & 0.14 & 0.08 & 0.12 & 0.15 & 0.16 & 0.27 & 0.39 \\
\hline MED & 0.43 & 0.44 & 0.40 & 0.35 & 0.27 & 0.16 & 0.12 & 0.38 & 0.23 & 0.21 & 0.32 & 0.57 \\
\hline AC-FT & 26 & 27 & 25 & 21 & 17 & 10 & 837 & 2550 & 497 & 13 & 19 & 108 \\
\hline CFSM & 0.00 & 0.00 & 0.00 & 0.00 & 0.00 & 0.00 & 0.03 & 0.09 & 0.02 & 0.00 & 0.00 & 0.00 \\
\hline \multicolumn{2}{|c|}{ Calendar year 2007} & \multicolumn{2}{|l|}{ Total 2,093.7 } & \multicolumn{2}{|l|}{ mean 5.74} & Max 336 & Min 0.08 & Median 0.33 & \multicolumn{2}{|c|}{ Acre-ft 4,150 } & \multicolumn{2}{|c|}{ CFSM 0.012} \\
\hline
\end{tabular}


Table 11. Discharge data (daily mean values), Polacca Wash near Second Mesa, Arizona (09400568), calendar year 2007. [e, estimated; CFSM, cubic feet per square mile; dashes indicate no data]

DISCHARGE, IN CUBIC FEET PER SECOND, CALENDAR YEAR 2007 DAILY MEAN VALUES

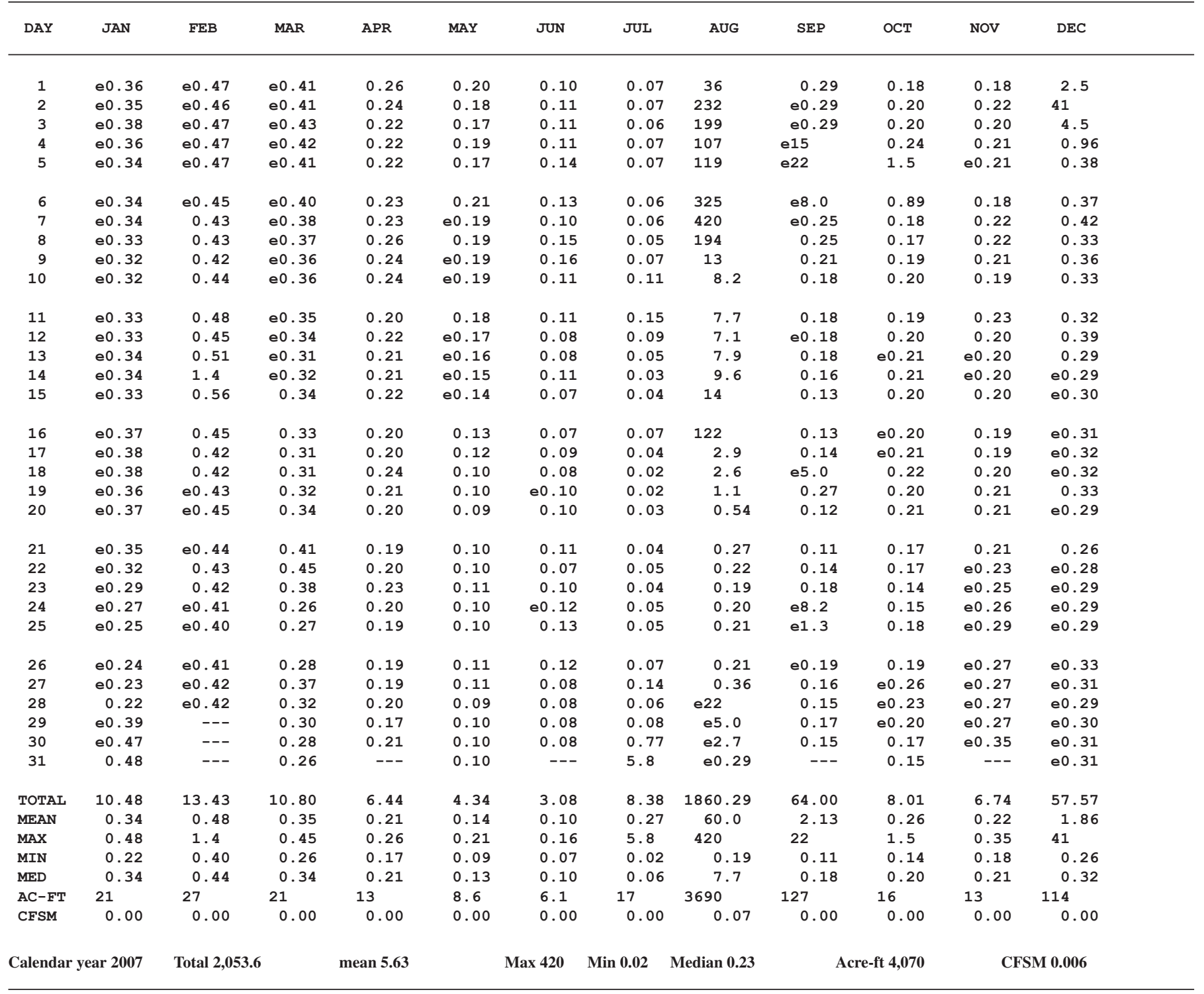


Table 12. Discharge data (daily mean values), Pasture Canyon Springs near Tuba City, Arizona (09401265), calendar year 2007.

[e, estimated; dashes indicate no data]

DISCHARGE, IN CUBIC FEET PER SECOND, CALENDAR YEAR 2007 DAILY MEAN VALUES

\begin{tabular}{|c|c|c|c|c|c|c|c|c|c|c|c|c|}
\hline DAY & JAN & FEB & MAR & APR & MAY & JUN & JUL & AUG & SEP & ОСт & NOV & DEC \\
\hline 1 & 0.36 & 0.43 & 0.38 & 0.36 & 0.32 & 0.28 & 0.28 & 0.28 & 0.28 & 0.30 & 0.34 & 0.49 \\
\hline 2 & 0.36 & 0.43 & 0.38 & 0.36 & 0.31 & 0.28 & 0.27 & 0.28 & 0.28 & 0.30 & 0.33 & 0.44 \\
\hline 3 & 0.36 & 0.42 & 0.38 & 0.36 & 0.31 & 0.29 & 0.26 & 0.28 & 0.28 & 0.30 & 0.32 & 0.43 \\
\hline 4 & 0.36 & 0.41 & 0.38 & 0.36 & 0.30 & 0.30 & 0.25 & 0.28 & 0.28 & 0.30 & 0.33 & 0.43 \\
\hline 5 & 0.36 & 0.41 & 0.37 & 0.36 & 0.30 & 0.30 & 0.25 & 0.28 & 0.28 & 0.31 & 0.34 & 0.42 \\
\hline 6 & 0.36 & 0.41 & 0.37 & 0.36 & 0.30 & 0.30 & 0.25 & 0.28 & 0.28 & 0.32 & 0.34 & 0.41 \\
\hline 7 & 0.36 & 0.41 & 0.36 & 0.36 & 0.30 & 0.30 & 0.25 & 0.28 & 0.28 & 0.32 & 0.32 & 0.41 \\
\hline 8 & 0.37 & 0.41 & 0.36 & 0.34 & 0.30 & 0.30 & 0.25 & 0.28 & 0.28 & 0.32 & 0.32 & 0.41 \\
\hline 9 & 0.38 & 0.41 & 0.36 & 0.33 & 0.30 & 0.30 & 0.25 & 0.28 & 0.28 & 0.32 & 0.32 & 0.41 \\
\hline 10 & 0.38 & 0.41 & 0.36 & 0.33 & 0.30 & 0.30 & 0.25 & 0.27 & 0.28 & 0.32 & 0.32 & 0.41 \\
\hline 11 & 0.38 & 0.41 & 0.36 & 0.33 & 0.30 & 0.30 & 0.25 & 0.27 & 0.27 & 0.32 & 0.33 & 0.39 \\
\hline 12 & 0.38 & 0.41 & 0.36 & 0.33 & 0.30 & 0.30 & 0.25 & 0.27 & 0.27 & 0.32 & 0.32 & 0.37 \\
\hline 13 & 0.38 & 0.41 & 0.36 & 0.34 & 0.30 & 0.30 & 0.25 & 0.27 & 0.27 & 0.32 & 0.33 & 0.36 \\
\hline 14 & 0.38 & 0.41 & 0.35 & 0.34 & 0.30 & 0.30 & 0.25 & 0.27 & 0.27 & 0.32 & 0.34 & 0.36 \\
\hline 15 & 0.38 & 0.41 & 0.35 & 0.33 & 0.30 & 0.30 & 0.25 & 0.27 & 0.27 & 0.32 & 0.34 & 0.36 \\
\hline 16 & 0.38 & 0.41 & 0.36 & 0.34 & 0.30 & 0.30 & 0.25 & 0.27 & 0.27 & 0.32 & 0.33 & 0.36 \\
\hline 17 & 0.38 & 0.41 & 0.36 & 0.33 & 0.30 & 0.30 & 0.25 & 0.27 & 0.28 & 0.32 & 0.30 & 0.36 \\
\hline 18 & 0.38 & 0.41 & 0.35 & 0.32 & 0.30 & 0.30 & 0.25 & 0.28 & 0.28 & 0.32 & 0.30 & 0.36 \\
\hline 19 & 0.40 & 0.41 & 0.35 & 0.32 & 0.30 & 0.30 & 0.25 & 0.29 & 0.28 & 0.32 & 0.30 & 0.36 \\
\hline 20 & 0.41 & 0.41 & 0.35 & 0.32 & 0.30 & 0.30 & 0.25 & 0.28 & 0.28 & 0.32 & 0.30 & 0.36 \\
\hline 21 & 0.41 & 0.41 & 0.36 & 0.32 & 0.30 & 0.29 & 0.25 & 0.28 & 0.28 & 0.34 & 0.31 & 0.35 \\
\hline 22 & 0.41 & 0.40 & 0.36 & 0.32 & 0.30 & 0.28 & 0.25 & 0.28 & 0.29 & 0.34 & 0.32 & 0.34 \\
\hline 23 & 0.41 & 0.38 & 0.48 & 0.32 & 0.58 & 0.28 & 0.26 & 0.28 & 0.30 & 0.34 & 0.32 & 0.34 \\
\hline 24 & 0.41 & 0.38 & e0. 44 & 0.32 & 0.38 & 0.29 & 0.27 & 0.29 & 0.30 & 0.34 & 0.32 & 0.34 \\
\hline 25 & 0.41 & 0.38 & e 0.40 & 0.32 & 0.33 & 0.28 & 0.27 & 0.29 & 0.30 & 0.34 & 0.32 & 0.34 \\
\hline 26 & 0.41 & 0.38 & e0. 37 & 0.32 & 0.31 & 0.32 & 0.26 & 0.29 & 0.30 & 0.34 & 0.32 & 0.34 \\
\hline 27 & 0.41 & 0.38 & 0.36 & 0.32 & 0.30 & 0.30 & 0.27 & 0.30 & 0.30 & 0.34 & 0.32 & 0.34 \\
\hline 28 & 0.41 & 0.38 & 0.36 & 0.32 & 0.28 & 0.29 & 0.29 & 0.30 & 0.30 & 0.34 & 0.32 & 0.36 \\
\hline 29 & 0.41 & --- & 0.36 & 0.32 & 0.28 & 0.29 & 0.28 & 0.30 & 0.30 & 0.34 & 0.33 & 0.36 \\
\hline 30 & 0.43 & --- & 0.36 & 0.32 & 0.28 & 0.28 & 0.28 & 0.29 & 0.30 & 0.35 & 0.36 & 0.36 \\
\hline 31 & 0.43 & --- & 0.36 & --- & 0.28 & --- & 0.28 & 0.29 & --- & 0.34 & --- & 0.36 \\
\hline TOTAL & 12.05 & 11.34 & 11.46 & 10.02 & 9.66 & 8.85 & 8.02 & 8.72 & 8.51 & 10.06 & 9.71 & 11.73 \\
\hline MEAN & 0.39 & 0.41 & 0.37 & 0.33 & 0.31 & 0.29 & 0.26 & 0.28 & 0.28 & 0.32 & 0.32 & 0.38 \\
\hline MAX & 0.43 & 0.43 & 0.48 & 0.36 & 0.58 & 0.32 & 0.29 & 0.30 & 0.30 & 0.35 & 0.36 & 0.49 \\
\hline MIN & 0.36 & 0.38 & 0.35 & 0.32 & 0.28 & 0.28 & 0.25 & 0.27 & 0.27 & 0.30 & 0.30 & 0.34 \\
\hline MED & 0.38 & 0.41 & 0.36 & 0.33 & 0.30 & 0.30 & 0.25 & 0.28 & 0.28 & 0.32 & 0.32 & 0.36 \\
\hline $\mathrm{AC}-\mathrm{FT}$ & 24 & 22 & 23 & 20 & 19 & 18 & 16 & 17 & 17 & 20 & 19 & 23 \\
\hline \multicolumn{2}{|c|}{ Calendar year 2007} & Total 120.13 & & Mean 0.33 & Max 0.58 & Min 0.25 & Median 0.32 & \multicolumn{2}{|c|}{ Acre-ft 238} & & & \\
\hline
\end{tabular}

Table 13. Date that monitoring program data collection began and drainage areas for streamflow-gaging stations, Black Mesa area, northeastern Arizona.

[Dashes indicate not determined]

\begin{tabular}{lccc}
\hline Station name & Station No. & Date data collection began & Drainage area (square miles) \\
\hline Moenkopi Wash at Moenkopi & 9401260 & July 1976 & 1,629 \\
Dinnebito Wash near Sand Springs & 9401110 & June 1993 & 473 \\
Polacca Wash near Second Mesa & 9400568 & April 1994 & 905 \\
Pasture Canyon Spring & 9401265 & August 2004 & -- \\
\hline
\end{tabular}


A. Annual average discharge for calendar years 1977-2007

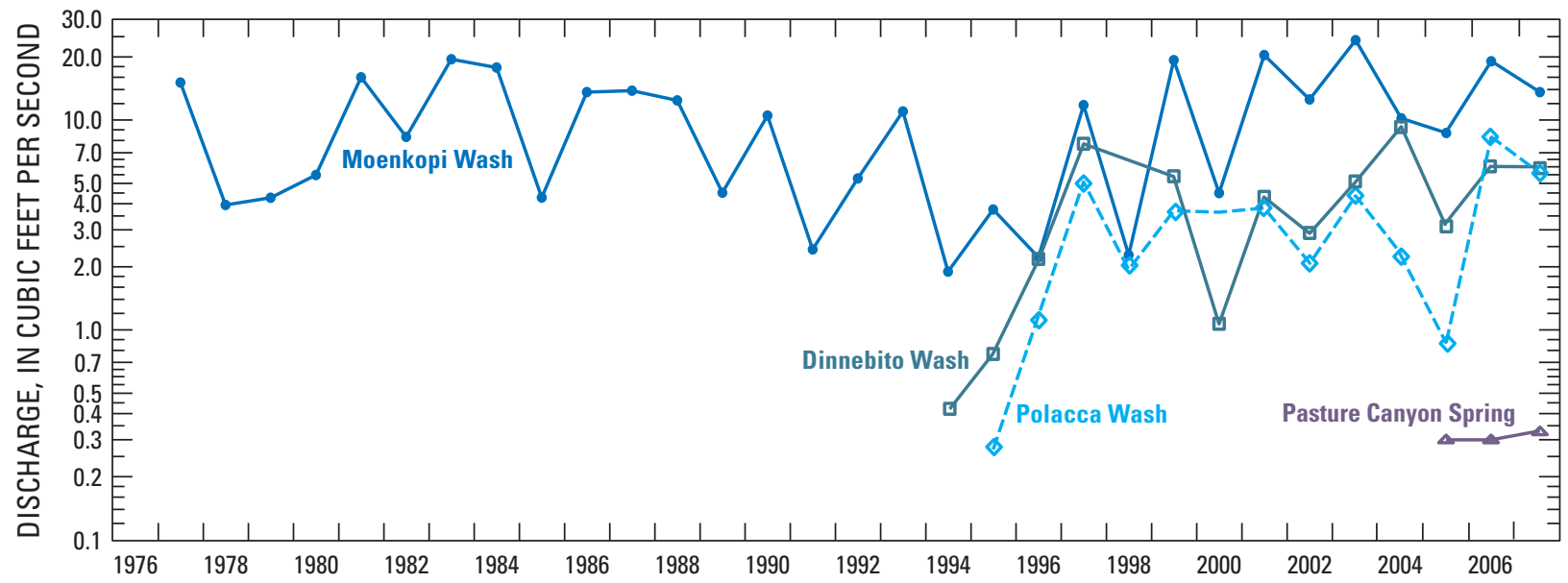

B. Annual precipitation at Betatakin, Arizona, calendar years 1976-2007 (National Weather Service)

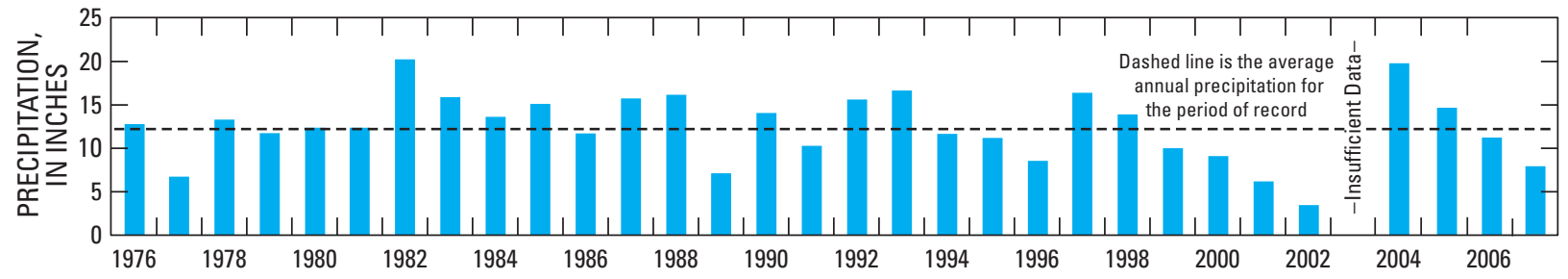

Figure 10. Annual average discharge at Moenkopi Wash at Moenkopi (09401260), Pasture Canyon Springs (09401265), Dinnebito Wash near Sand Spring (09401110), and Polacca Wash near Second Mesa (09400568), and annual precipitation at Betatakin, Arizona, Black Mesa area, northeastern Arizona. A, Annual average discharge for calendar years 1977-2007; B, Annual precipitation at Betatakin, northeastern Arizona, calendar years 1976-2007 (National Park Service, Betatakin National Monument, written commun., 2008). 
A. Median winter flow for November, December, January, February, 1977-2007, for Moenkopi Wash at Moenkopi (09401260).

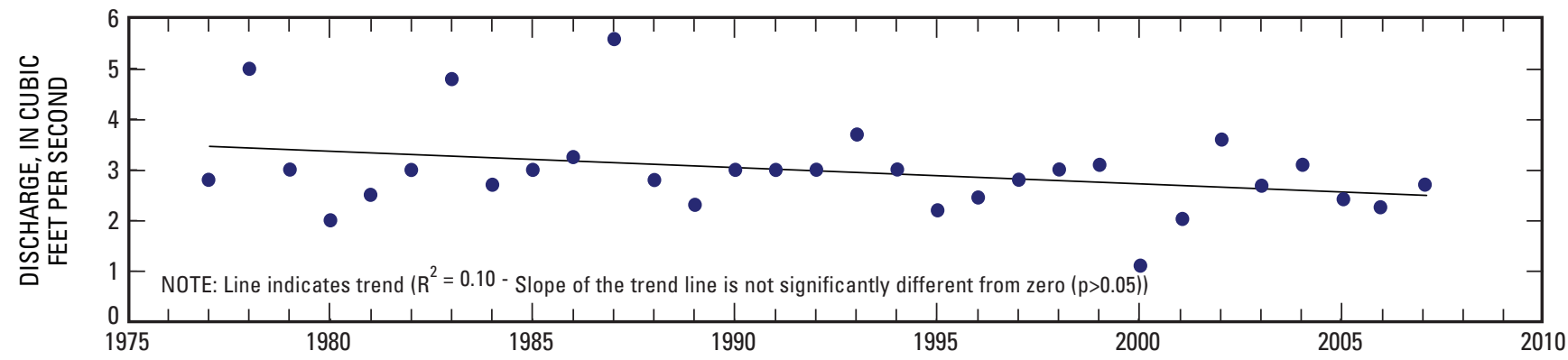

B. Median winter flow for November, December, January, February, 1996-2007, Dinnebito Wash near Sand Spring (09401110).

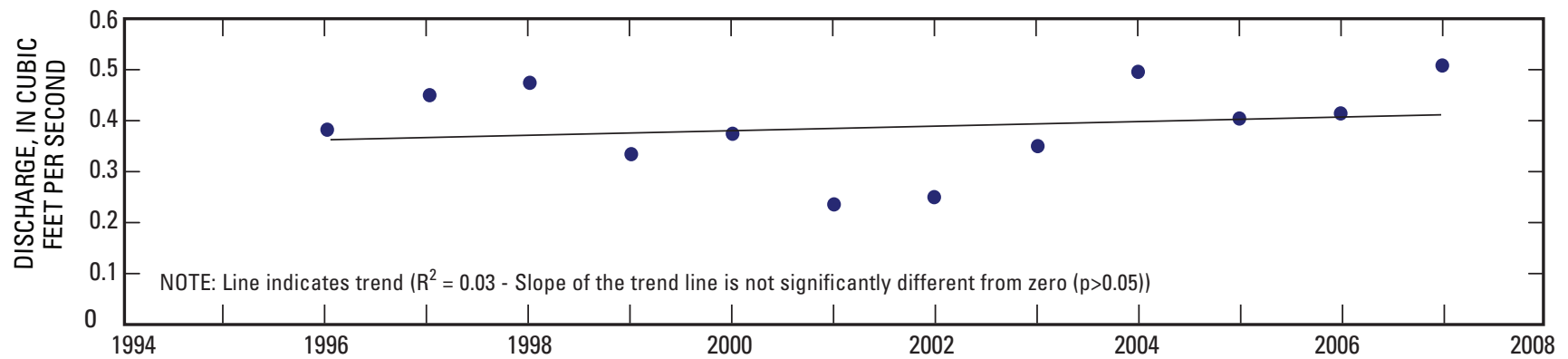

C. Median winter flow for November, December, January, February, 1996-2007, Polacca Wash near Second Mesa (09400568).

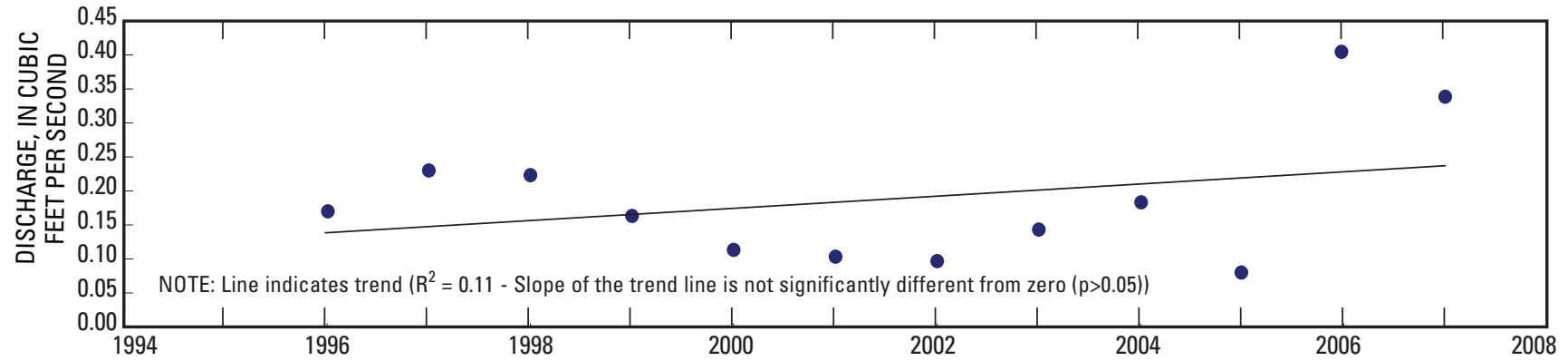

Figure 11. Median winter flow for November, December, January, and February for water years 1977-2007 for (A) Moenkopi Wash at Moenkopi (09401260), (B) Dinnebito Wash near Sand Springs (09401110), and (C) Polacca Wash near Second Mesa (09400568), Black Mesa area, northeastern Arizona. Median winter flow is calculated by computing the median flow for 120 consecutive daily mean flows for winter months- November, December, January, and February. Note: Trend lines were generated using the method of least squares. 
samples were collected from six wells: Keams Canyon PM2, Kykotsmovi PM2, Piñon NTUA 1, Forest Lake NTUA 1, Peabody 2, and Peabody 8 (figs. 8, 12 and table 14).

Keams Canyon PM2 yielded the highest dissolvedsolids concentration (607 mg/L) and chloride concentration (95 mg/L) of the six wells sampled (table 15 and fig. 13). Dissolved-solids concentrations in the other five wells ranged from $120 \mathrm{mg} / \mathrm{L}$ at Peabody 2 to $362 \mathrm{mg} / \mathrm{L}$ at Forest Lake NTUA 1, and their chloride concentrations ranged from 2.0 $\mathrm{mg} / \mathrm{L}$ at Peabody 2 to $36 \mathrm{mg} / \mathrm{L}$ at Forest Lake NTUA 1 (table 15 and fig. 13). Peabody 8 had the highest sulfate concentration $(117 \mathrm{mg} / \mathrm{L})$ of the six wells, and the others ranged from $7.5 \mathrm{mg} / \mathrm{L}$ at Peabody 2 to $73 \mathrm{mg} / \mathrm{L}$ at Forest Lake NTUA 1 (table 15 and fig. 13).

Chemical constituents analyzed from the six wells were compared to the U.S. Environmental Protection Agency (USEPA) primary and secondary drinking water standards (U.S. Environmental Protection Agency, 2003). Maximum Contaminant Levels (MCLs), which are the primary regulations, are legally enforceable standards that apply to public water systems. MCLs protect drinking-water quality by limiting the levels of specific contaminants that can adversely affect public health. Secondary Maximum Contaminant Levels (SMCLs) provide guidelines for the control of contaminants that may cause cosmetic effects (such as skin or tooth discoloration) or aesthetic effects (such as taste, odor, or color) in drinking water. The USEPA recommends compliance with SMCLs for public water systems; however, compliance is not enforced.

In 2008, most of the analyzed constituents from the six wells were below the USEPA MCL or SMCL for drinking water. Only one MCL was exceeded from constituents analyzed from the six wells-Keams Canyon PM2 had an arsenic value of $0.0419 \mathrm{mg} / \mathrm{L}$, and that exceeds the USEPA MCL of $0.01 \mathrm{mg} / \mathrm{L}$ for arsenic. The USEPA SMCL for concentration of dissolved solids $(500 \mathrm{mg} / \mathrm{L})$ was also exceeded at Keams Canyon PM2 (607 mg/L). In addition, the USEPA SMCL for $\mathrm{pH}$ (6.5 to 8.5) was exceeded at Keams Canyon PM2,
Kykotsmovi PM2, Piñon NTUA 1, Forest Lake NTUA 1, and Peabody 2 (U.S. Environmental Protection Agency, 2003; table 14). A linear regression analysis was used to determine trends in concentrations of dissolved solids, chloride, and sulfate from the six wells, and for the period of record no trends were found $(\mathrm{p}>0.05)$.

\section{Water-Chemistry Data for Springs that Discharge from the N Aquifer}

In 2008, water samples were collected from Moenkopi School Spring and Pasture Canyon Spring in the southwestern part of the Black Mesa study area (fig. 8). Both springs discharge water from the unconfined part of the $\mathrm{N}$ aquifer. At Moenkopi School Spring, samples were collected from a horizontal metal pipe that is developed into the hillside to collect water from the spring, and at Pasture Canyon Spring, samples were collected from a pipe at the end of a channel that is approximately 50 feet away from the spring.

The samples from Moenkopi School Spring and Pasture Canyon Spring yielded a calcium bicarbonate-type water (fig. 12 and table 16). Samples from Moenkopi School Spring and Pasture Canyon Spring had dissolved solid concentrations of $230 \mathrm{mg} / \mathrm{L}$ and $149 \mathrm{mg} / \mathrm{L}$, respectively (tables 16 and 17). Concentrations of chloride and sulfate were higher at Moenkopi School Spring than Pasture Canyon Spring. Concentrations of all the analyzed constituents in samples from both springs were less than current USEPA MCLs and SMCLs (U.S. Environmental Protection Agency, 2003).

There are increasing trends in concentrations of dissolved solids, chloride, and sulfate in water from Moenkopi School Spring (table 17 and fig. 14). Concentrations of the same constituents in Pasture Canyon Spring did not show any trends (table 17 and fig. 14). 


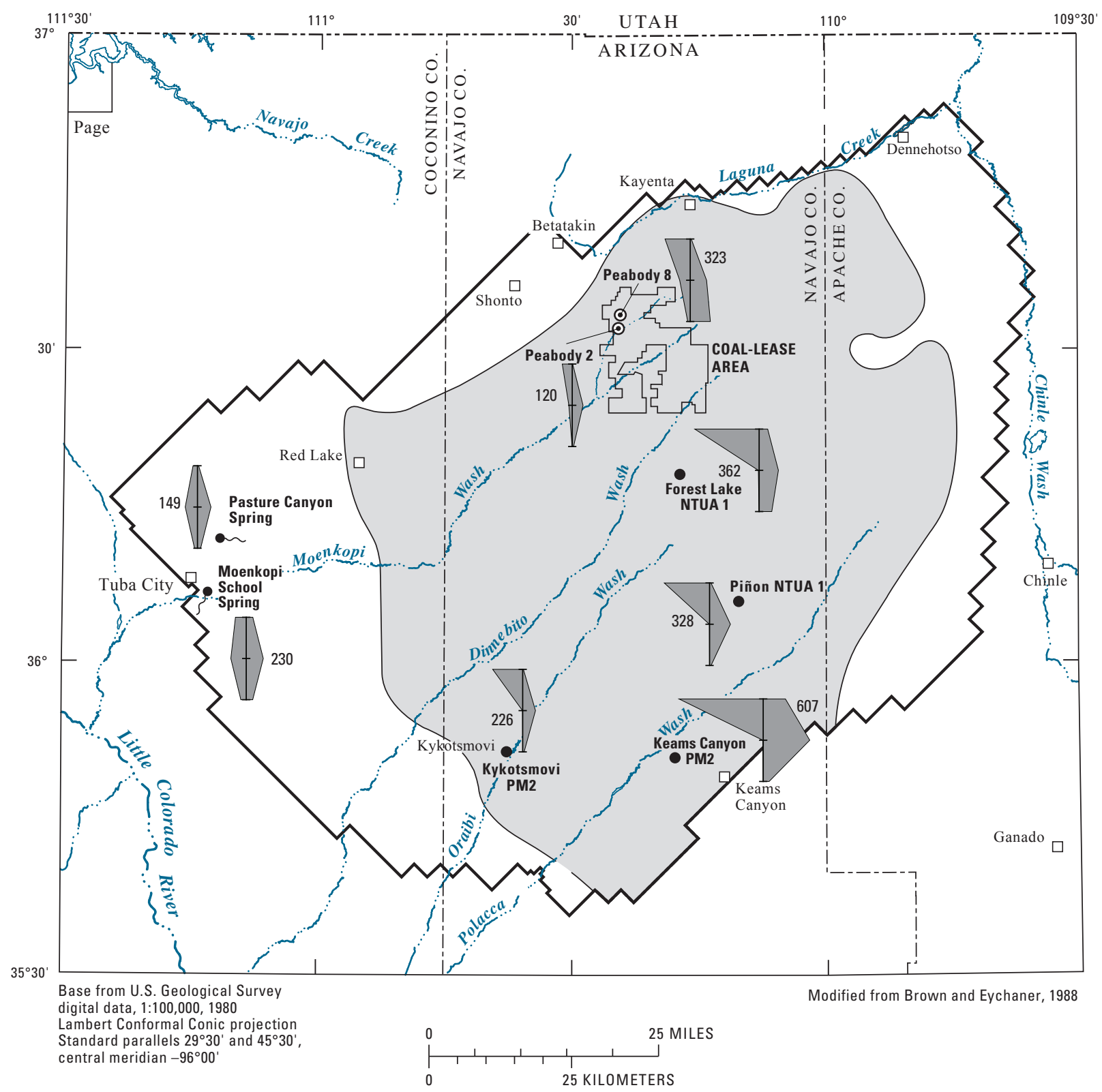

EXPLANATION

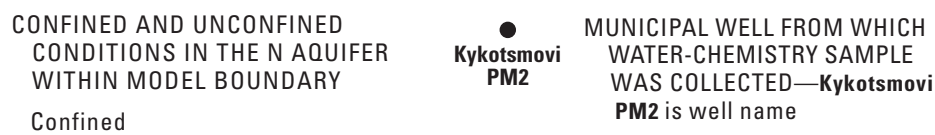

Unconfined

APPROXIMATE BOUNDARY BETWEEN CONFINED AND UNCONFINED CONDITIONS From Brown and Eychaner (1988)

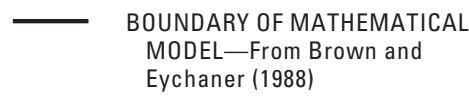
Eychaner (1988)

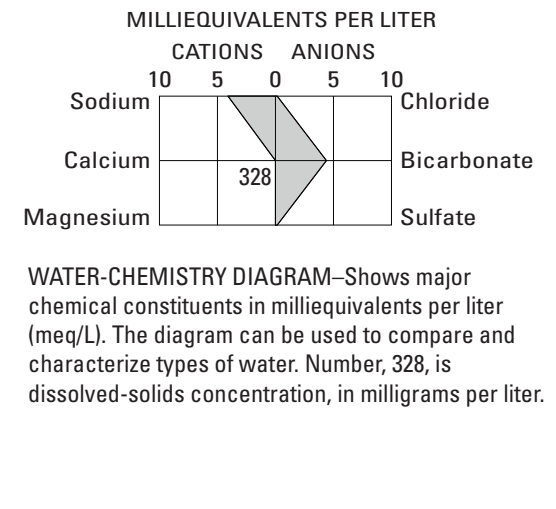

Figure 12. Water chemistry and distribution of dissolved solids in the N aquifer, Black Mesa area, northeastern Arizona, 2008. 
Table 14. Physical properties and chemical analyses of water from selected industrial and municipal wells completed in the N aquifer, Black Mesa area, northeastern Arizona, 2008.

$\left[{ }^{\circ} \mathrm{C}\right.$, degrees Celsius; $\mu \mathrm{S} / \mathrm{cm}$, microsiemens per centimeter at $25^{\circ} \mathrm{C} ; \mathrm{mg} / \mathrm{L}$, milligrams per liter; E, estimated; $\mu \mathrm{g} / \mathrm{L}$, micrograms per liter; $<$, less than. Dashes indicate no data]

\begin{tabular}{|c|c|c|c|c|c|c|c|c|c|c|c|}
\hline Common well name & $\begin{array}{l}\text { U.S. Geological Survey } \\
\text { identification number }\end{array}$ & $\begin{array}{c}\text { Date } \\
\text { of } \\
\text { samples }\end{array}$ & $\begin{array}{l}\text { Temperature } \\
\left.\text { field ( }{ }^{\circ} \mathrm{C}\right)\end{array}$ & $\begin{array}{c}\text { Specific } \\
\text { conductance } \\
\text { field } \mu \mathrm{S} / \mathrm{cm}\end{array}$ & $\begin{array}{c}\mathrm{pH} \\
\text { field } \\
\text { (units) }\end{array}$ & $\begin{array}{c}\text { Alkalinity, } \\
\text { field, dissolved } \\
\text { (mg/L as } \mathrm{CaCO}_{3} \text { ) }\end{array}$ & $\begin{array}{c}\text { Nitrogen } \\
\text { N02 + } \\
\text { N03 } \\
\text { dissolved } \\
\text { mg/L as N }\end{array}$ & $\begin{array}{c}\text { Ortho- } \\
\text { Phosphate } \\
\text { dissolved } \\
\text { (mg/L as P) }\end{array}$ & $\begin{array}{l}\text { Calcium } \\
\text { dissolved } \\
\text { (mg/L as } \\
\text { Ca) }\end{array}$ & $\begin{array}{c}\text { Magnesium } \\
\text { dissolved } \\
\text { (mg/L as } \\
\mathrm{Mg})\end{array}$ & $\begin{array}{c}\text { Potassium } \\
\text { dissolved } \\
\text { (mg/L as K) }\end{array}$ \\
\hline Keams Canyon PM2 & 355023110182701 & 05-06-08 & 19.8 & 1079 & 9.2 & 356.0 & $<.04$ & 0.011 & 0.81 & 0.159 & 0.78 \\
\hline Kykotsmovi PM & 2355215110375001 & 05-06-08 & 23.1 & 373 & 9.8 & 166.7 & 1.17 & 0.033 & 0.48 & E.013 & 0.41 \\
\hline Pinon NTUA 1 & 360527110122501 & $05-07-08$ & 20.5 & 565 & 10.0 & 266.4 & 1.05 & 0.019 & 0.49 & 0.026 & 0.41 \\
\hline Forest Lake NTUA 1 & 361737110180301 & 05-07-08 & 27.8 & 424 & 9.6 & 162.5 & 0.37 & 0.011 & 1.92 & 0.226 & 1.00 \\
\hline Peabody 2 & 363005110250901 & $05-08-08$ & 31.0 & 160 & 8.8 & 72.5 & 0.95 & 0.012 & 8.15 & 0.132 & 0.71 \\
\hline Peabody 8 & 363130110254501 & 05-08-08 & 29.7 & 457 & 8.2 & 101.7 & 1.69 & 0.011 & 25.5 & 3.670 & 2.79 \\
\hline
\end{tabular}

\begin{tabular}{|c|c|c|c|c|c|c|c|c|c|c|c|}
\hline Common well name & $\begin{array}{l}\text { U.S. Geological Survey } \\
\text { identification number }\end{array}$ & $\begin{array}{c}\text { Date } \\
\text { of } \\
\text { samples }\end{array}$ & $\begin{array}{c}\text { Sodium } \\
\text { dissolved } \\
\text { (mg/L as Na) }\end{array}$ & $\begin{array}{c}\text { Chloride } \\
\text { dissolved } \\
\text { (mg/L as Cl) }\end{array}$ & $\begin{array}{c}\text { Flouride } \\
\text { dissolved } \\
\text { (mg/L as F) }\end{array}$ & $\begin{array}{c}\text { Silica } \\
\text { dissolved } \\
\left(\mathrm{mg} / \mathrm{L} \text { as } \mathrm{SiO}_{2}\right)\end{array}$ & $\begin{array}{c}\text { Sulfate } \\
\text { dissolved } \\
\left(\mathrm{mg} / \mathrm{L} \text { as } \mathrm{SO}_{4}\right)\end{array}$ & $\begin{array}{c}\text { Arsenic } \\
\text { dissolved } \\
\text { (ug/L as As) }\end{array}$ & $\begin{array}{c}\text { Boron } \\
\text { dissolved } \\
\text { (ug/L as B) }\end{array}$ & $\begin{array}{c}\text { Iron } \\
\text { dissolved } \\
\text { (ug/L as Fe) }\end{array}$ & $\begin{array}{c}\text { Dissolved } \\
\text { solids residue } \\
\text { at } 180^{\circ} \mathrm{C}(\mathrm{mg} / \mathrm{L})\end{array}$ \\
\hline Keams Canyon PM2 & 355023110182701 & 05-06-08 & 234 & 95.1 & 1.40 & 12.6 & 34.5 & 41.9 & 634 & $<8$ & 607 \\
\hline Kykotsmovi PM2 & 355215110375001 & $05-06-08$ & 83.3 & 3.04 & 0.18 & 24.2 & 8.2 & 5.2 & 31 & $<8$ & 226 \\
\hline Pinon NTUA 1 & 360527110122501 & $05-07-08$ & 126 & 6.15 & 0.29 & 25.9 & 8.7 & 4.8 & 67 & $<8$ & 328 \\
\hline Forest Lake NTUA 1 & 361737110180301 & $05-07-08$ & 179 & 36.5 & 0.70 & 19.6 & 73.2 & 1.4 & 384 & 100 & 362 \\
\hline Peabody 2 & 363005110250901 & $05-08-08$ & 27.6 & 2.04 & E. 12 & 22.5 & 7.5 & 2.7 & 17 & $<8$ & 120 \\
\hline Peabody 8 & 363130110254501 & 05- $08-08$ & 69.9 & 4.44 & 0.15 & 20.0 & 117 & 1.8 & 43 & $<8$ & 323 \\
\hline
\end{tabular}


Table 15. Specific conductance and concentrations of selected chemical constituents in water samples from industrial and municipal wells completed in the N aquifer, Black Mesa area, northeastern Arizona, 1974-2008.

$\left[\mu \mathrm{S} / \mathrm{cm}\right.$, microsiemens per centimeter at $25^{\circ} \mathrm{C} ;{ }^{\circ} \mathrm{C}$, degrees Celsius; $\mathrm{mg} / \mathrm{L}$, milligram per liter; $<$, less than. Dashes indicate no data]

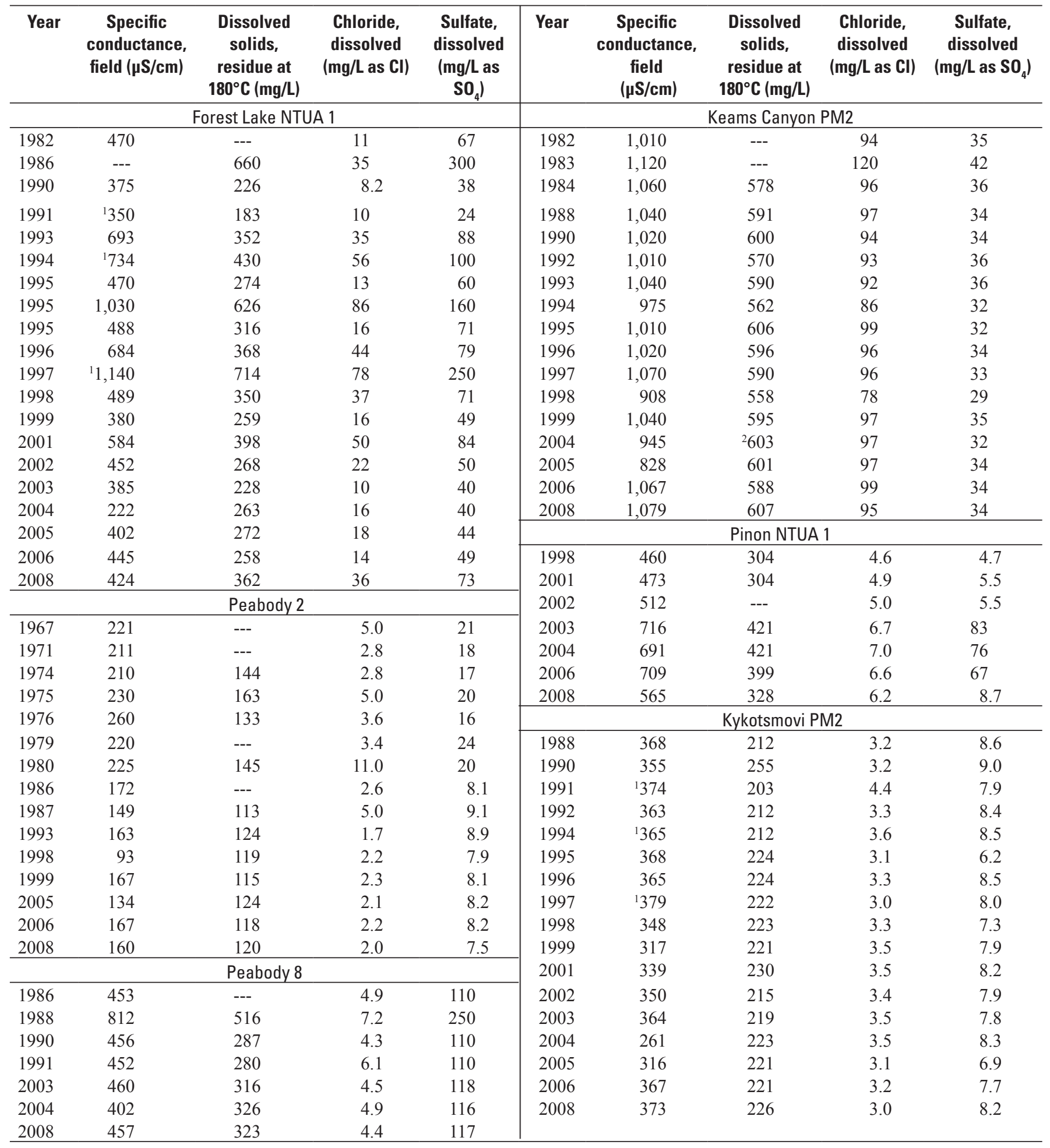

${ }^{1}$ Value is different in Black Mesa monitoring reports printed before 2000. The earlier reports showed values determined by laboratory analysis.

${ }^{2}$ Value is different in Black Mesa monitoring report printed in 2004. 
Table 16. Physical properties and chemical analyses of water samples from Moenkopi School Spring and Pasture Canyon Spring, Black Mesa area, northeastern Arizona, 2008.

$\left[{ }^{\circ} \mathrm{C}\right.$, degree Celsius; $\mu \mathrm{S} / \mathrm{cm}$, microsiemens per centimeter at $25^{\circ} \mathrm{C} ; \mathrm{mg} / \mathrm{L}$, milligrams per liter; $\mu \mathrm{g} / \mathrm{L}$, micrograms per liter; $<$, less than. Dashes indicate no data; e, estimated]

\begin{tabular}{|c|c|c|c|c|c|c|c|c|c|c|c|c|}
\hline $\begin{array}{l}\text { U.S. Geological Survey } \\
\text { identification number }\end{array}$ & $\begin{array}{c}\text { Bureau } \\
\text { of } \\
\text { Indian Affairs } \\
\text { site number } \\
\end{array}$ & $\begin{array}{c}\text { Common } \\
\text { spring name }\end{array}$ & $\begin{array}{c}\text { Date } \\
\text { of } \\
\text { samples }\end{array}$ & $\begin{array}{l}\text { Temperature } \\
\text { field (oC) }\end{array}$ & $\begin{array}{c}\text { Specific } \\
\text { Conductance } \\
\text { Field }(\mu \mathrm{S} / \mathrm{cm})\end{array}$ & $\begin{array}{c}\mathrm{pH} \\
\text { field (units) }\end{array}$ & $\begin{array}{c}\text { Alkalinity, } \\
\text { field, } \\
\text { dissolved } \\
\left(\mathrm{mg} / \mathrm{L} \text { as } \mathrm{CaCO}_{3} \text { ) }\right.\end{array}$ & $\begin{array}{c}\text { Nitrogen } \\
\text { NO2 + N03 } \\
\text { dissolved } \\
\text { mg/L as N }\end{array}$ & $\begin{array}{l}\text { Ortho-Phosphate } \\
\text { dissolved } \\
\text { (mg/L as P) }\end{array}$ & $\begin{array}{l}\text { Calcium dissolved } \\
\quad(\mathrm{mg} / \mathrm{L} \text { as } \mathrm{Ca})\end{array}$ & $\begin{array}{l}\text { Magnesium dissolved } \\
(\mathrm{mg} / \mathrm{L} \text { as } \mathrm{Mg})\end{array}$ & $\begin{array}{l}\text { Potassium dis- } \\
\text { solved (mg/L as } \mathrm{K})\end{array}$ \\
\hline 360632111131101 & 3GS-77-6 & $\begin{array}{c}\text { Moenkopi } \\
\text { School } \\
\text { Spring }\end{array}$ & $05-28-08$ & 17.5 & 390 & 7.3 & 103.5 & 2.58 & 0.010 & 37.3 & 7.90 & 1.45 \\
\hline 361021111115901 & $3 A-5$ & $\begin{array}{l}\text { Pasture } \\
\text { Canyon } \\
\text { Spring }\end{array}$ & $05-28-08$ & 17.4 & 240 & 7.9 & 82.5 & 4.34 & 0.018 & 29.7 & 4.39 & 1.28 \\
\hline $\begin{array}{l}\text { U.S. Geological Survey } \\
\text { identification number }\end{array}$ & $\begin{array}{c}\text { Bureau } \\
\text { of } \\
\text { Indian Affairs } \\
\text { site number }\end{array}$ & $\begin{array}{c}\text { Common } \\
\text { spring name }\end{array}$ & $\begin{array}{c}\text { Date } \\
\text { of } \\
\text { samples }\end{array}$ & $\begin{array}{c}\text { Sodium } \\
\text { dissolved } \\
\text { (mg/L as Na) }\end{array}$ & $\begin{array}{c}\text { Chloride } \\
\text { dissolved } \\
\text { (mg/L as Cl) }\end{array}$ & $\begin{array}{c}\text { Flouride } \\
\text { dissolved } \\
\text { (mg/L as F) }\end{array}$ & $\begin{array}{c}\text { Silica } \\
\text { dissolved } \\
\left(\mathrm{mg} / \mathrm{L} \text { as } \mathrm{SiO}_{2}\right)\end{array}$ & $\begin{array}{c}\text { Sulfate } \\
\text { dissolved } \\
\text { (mg/L as } \\
\left.\mathrm{SO}_{4}\right)\end{array}$ & $\begin{array}{c}\text { Arsenic } \\
\text { dissolved } \\
\text { ( } \mu \mathrm{g} / \mathrm{L} \text { as As) }\end{array}$ & $\begin{array}{l}\text { Boron dissolved } \\
(\mu \mathrm{g} / \mathrm{L} \text { as B })\end{array}$ & $\begin{array}{c}\text { Iron } \\
\text { dissolved } \\
(\mu \mathrm{g} / \mathrm{L} \text { as } \mathrm{Fe})\end{array}$ & $\begin{array}{c}\text { Dissolved } \\
\text { solids residue } \\
\text { at } \\
180^{\circ} \mathrm{C}(\mathrm{mg} / \mathrm{L}) \\
\end{array}$ \\
\hline 360632111131101 & $3 \mathrm{GS}-77-6$ & $\begin{array}{l}\text { Moenkopi } \\
\text { School } \\
\text { Spring }\end{array}$ & $05-28-08$ & 29.9 & 28.3 & 0.18 & 14.1 & 37.6 & $2.4^{(1)}$ & 43 & $<8$ & 230 \\
\hline 361021111115901 & $3 \mathrm{~A}-5$ & $\begin{array}{l}\text { Pasture } \\
\text { Canyon } \\
\text { Spring }\end{array}$ & $05-28-08$ & 12.4 & 5.01 & 0.16 & 10.1 & 18.3 & $1.8^{(1)}$ & 33 & $<8$ & 149 \\
\hline
\end{tabular}

${ }^{1}$ Arsenic sample was collected on 06-03-08 
A. Dissolved solids concentration Forest Lake NTUA 1, 1986-2008

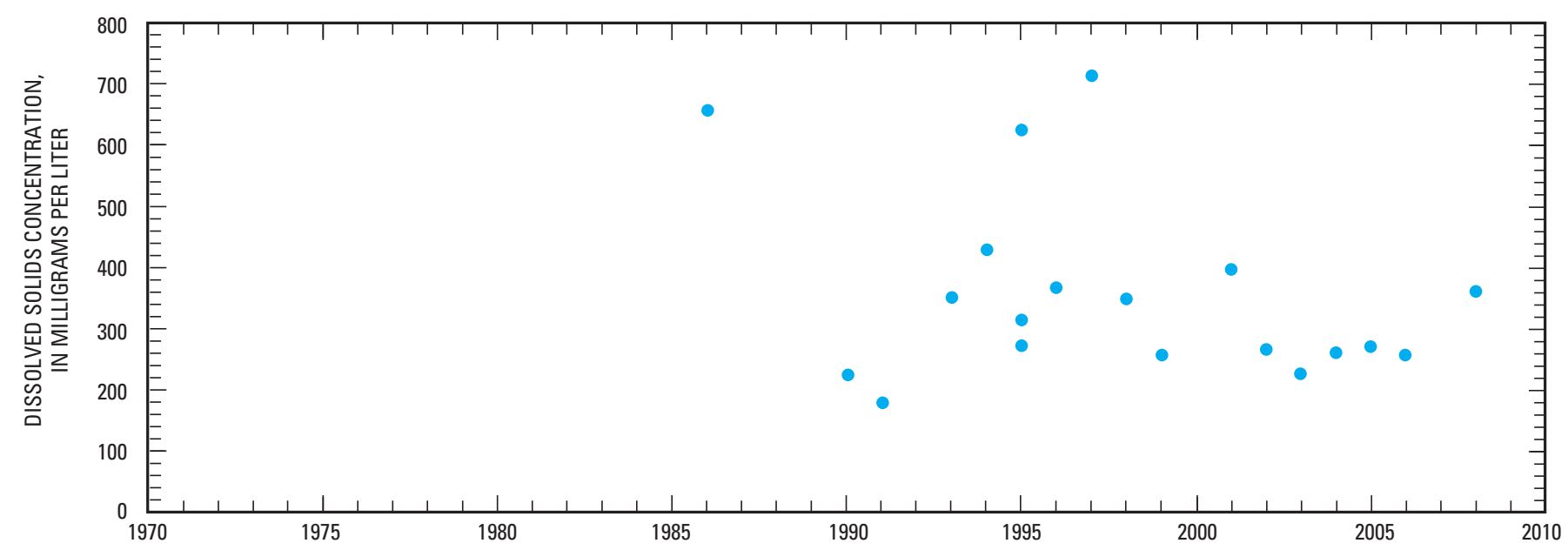

B. Dissolved solids concentration Peabody 2, 1974-2008

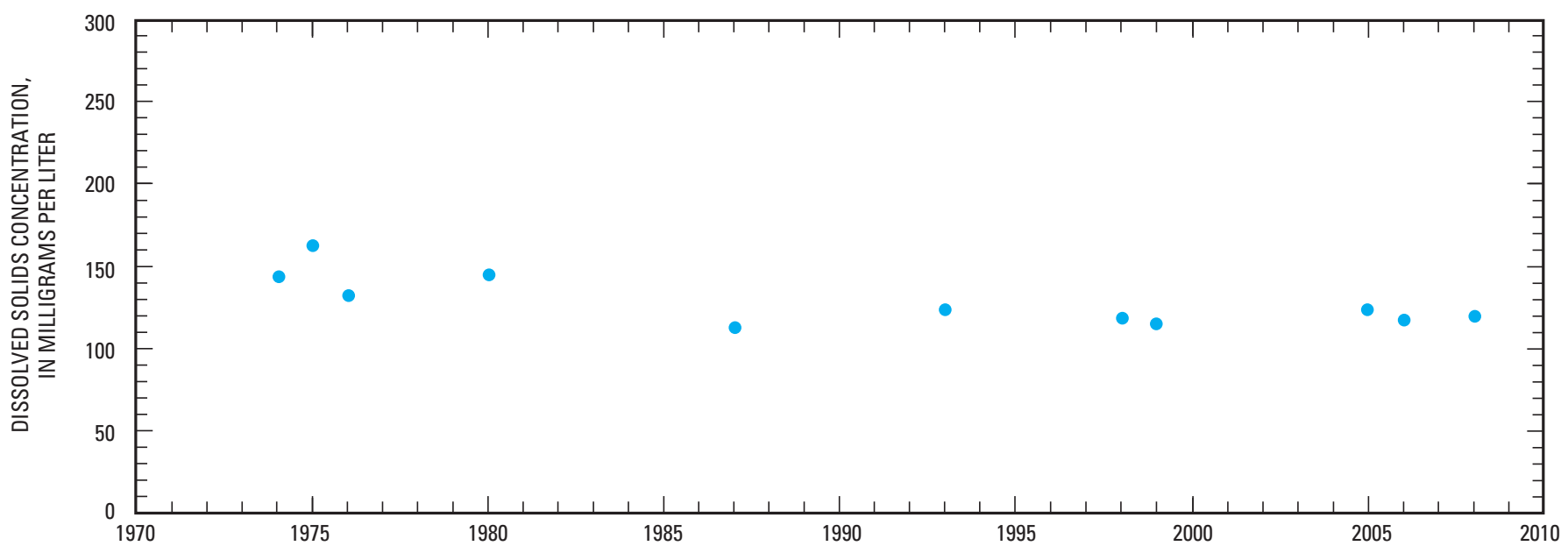

C. Dissolved solids concentration Peabody 8, 1988-2008

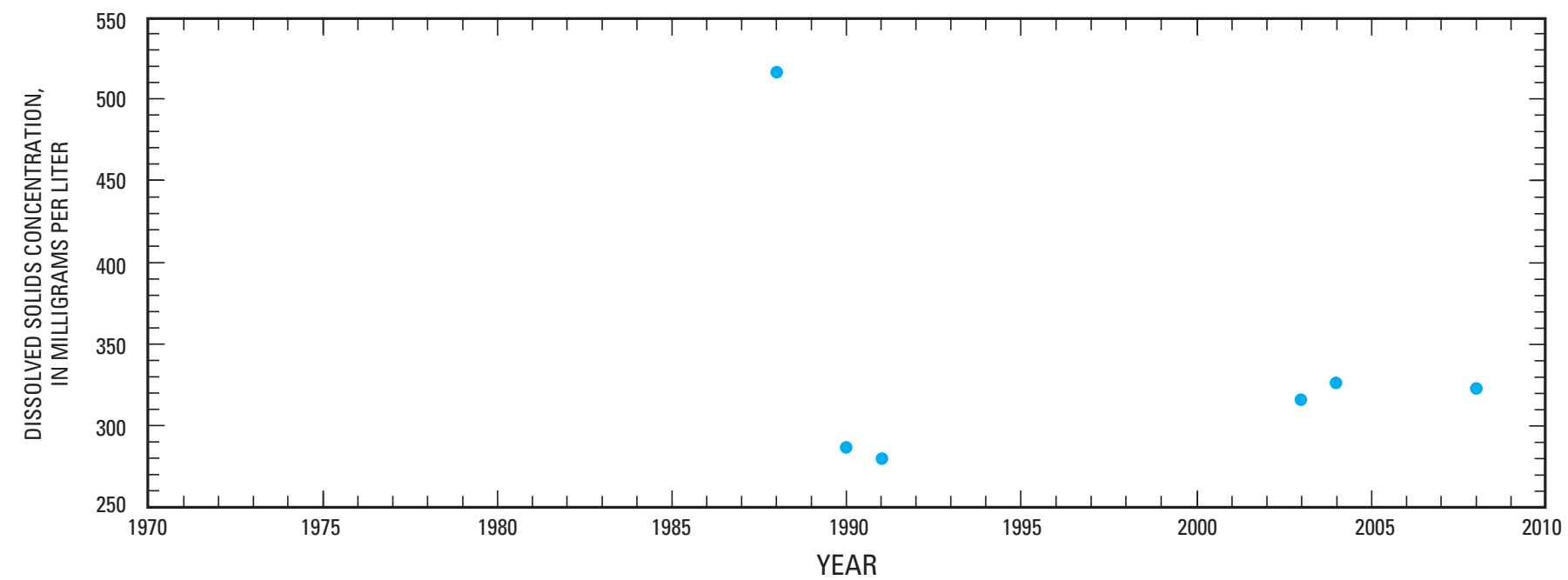

Figure 13. Dissolved-solids concentrations for water samples from selected wells, $\mathrm{N}$ aquifer, Black Mesa area, northeastern Arizona, 1974-2008. A, Forest Lake NTUA 1, 1986-2008. B, Peabody 2, 1974-2008. C, Peabody 8, 1988-2008. D, Keams Canyon PM2, 1984-2008. E, Pinon NTUA 1, 1998-2008. F, Kykotsmovi PM2, 1988-2008 
D. Dissolved solids concentrations Keams canyon PM2, 1984-2008

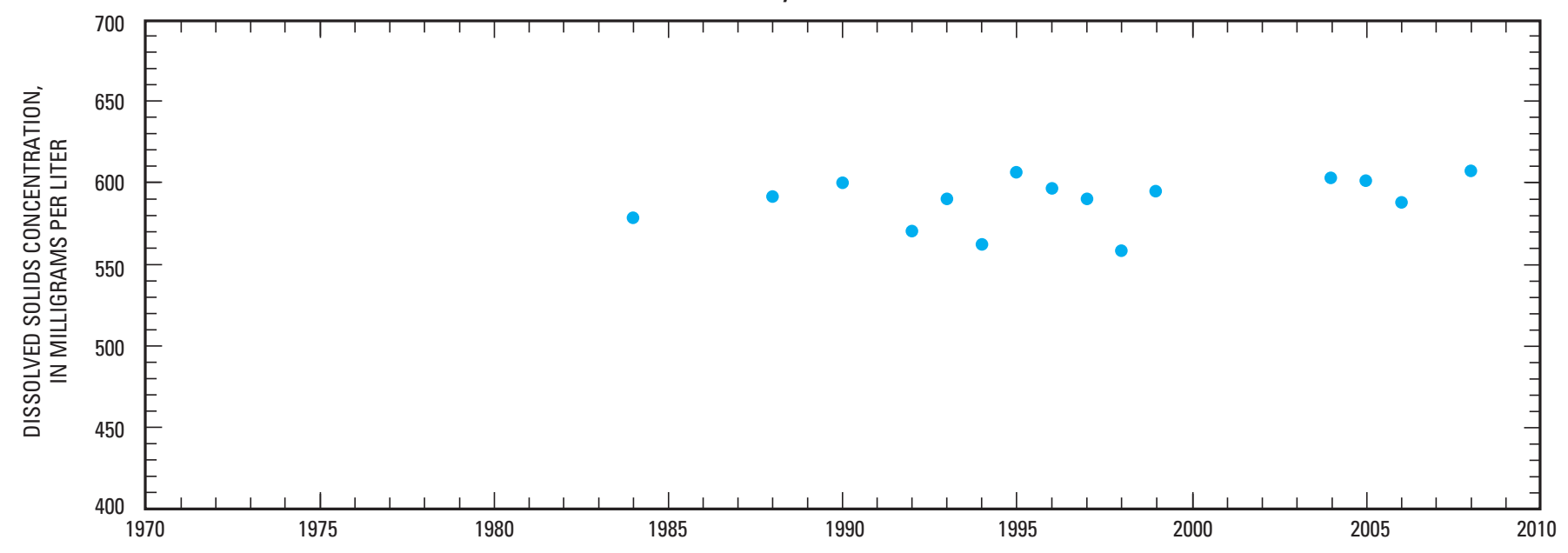

E. Dissolved solids concentrations Pinon NTUA 1, 1998-2008

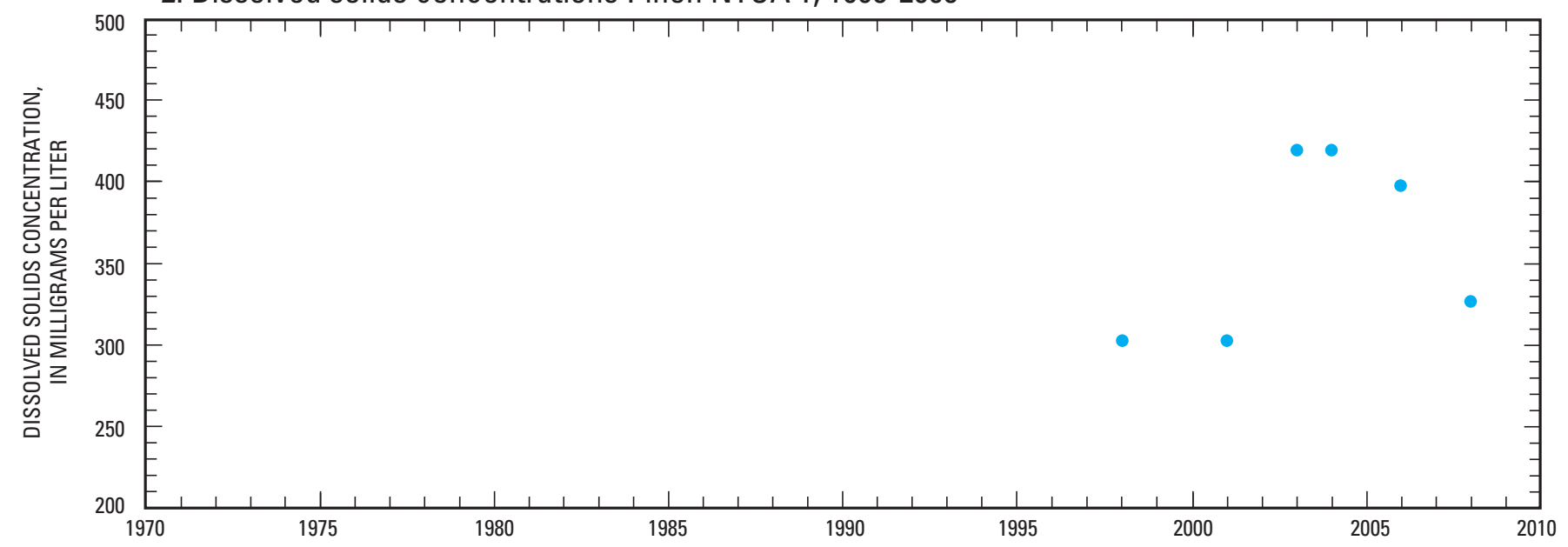

F. Dissolved solids concentrations Kykotsmovi PM2, 1988-2008

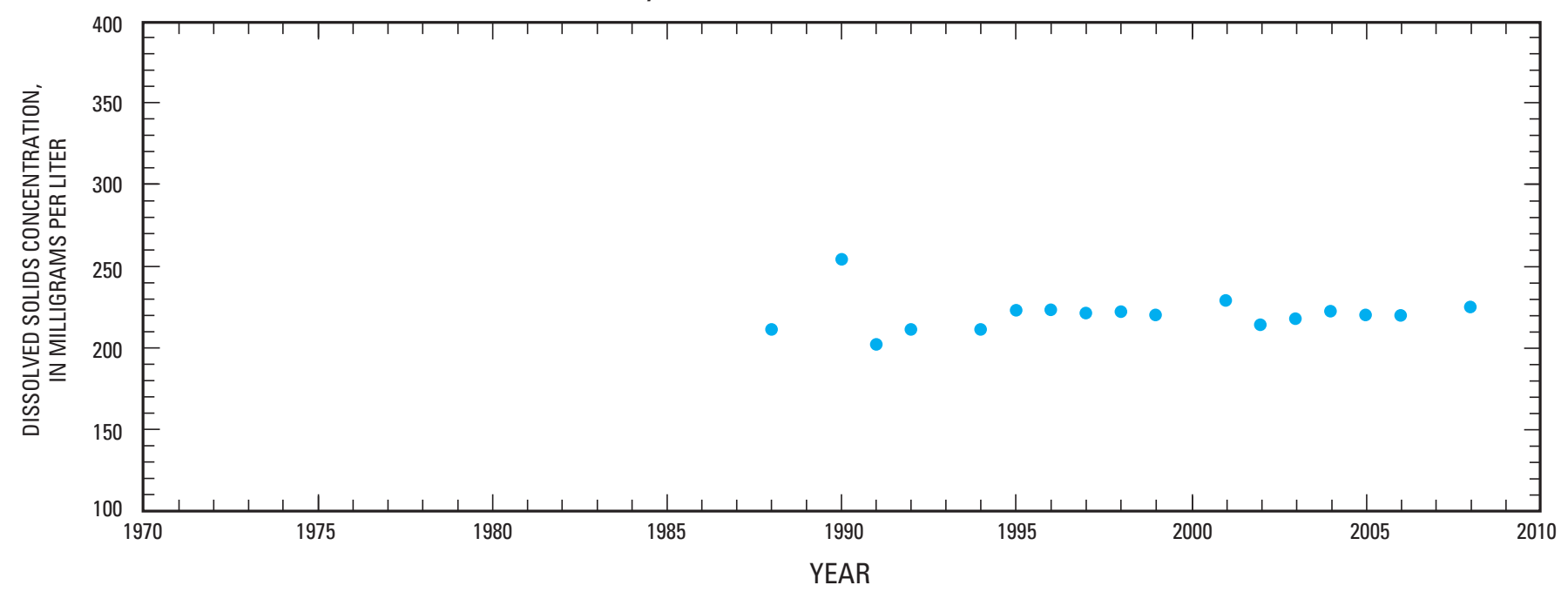

Figure 13. Continued 
Table 17. Specific conductance and concentrations of selected chemical constituents in N-aquifer water samples from Moenkopi School Spring and Pasture Canyon Spring, Black Mesa area, northeastern Arizona, 1948-2008.

$\left[\mu \mathrm{S} / \mathrm{cm}\right.$, microsiemens per centimeter at $25^{\circ} \mathrm{C} ; \mathrm{mg} / \mathrm{L}$, milligrams per liter; ${ }^{\circ} \mathrm{C}$, degrees Celsius. Dashes indicate no data]

\begin{tabular}{|c|c|c|c|c|}
\hline Year & $\begin{array}{l}\text { Specific conductance, } \\
\text { field, in } \mu S / c m\end{array}$ & $\begin{array}{c}\text { Dissolved solids, } \\
\text { residue at } \\
180^{\circ} \mathrm{C} \text {, in } \mathrm{mg} / \mathrm{L}\end{array}$ & $\begin{array}{c}\text { Chloride, dissolved, } \\
\text { in } \\
\mathrm{mg} / \mathrm{L} \text { as } \mathrm{Cl}\end{array}$ & $\begin{array}{c}\text { Sulfate, dissolved, } \\
\text { in } \\
\mathrm{mg} / \mathrm{L} \mathrm{as} \mathrm{SO}_{4}\end{array}$ \\
\hline \multicolumn{5}{|c|}{ Moenkopi School Spring } \\
\hline 1952 & 222 & --- & 6 & --- \\
\hline 1987 & 270 & 161 & 12 & 19 \\
\hline 1988 & 270 & 155 & 12 & 19 \\
\hline 1991 & 297 & 157 & 14 & 20 \\
\hline 1993 & 313 & 204 & 17 & 27 \\
\hline 1994 & 305 & 182 & 17 & 23 \\
\hline 1995 & 314 & 206 & 18 & 22 \\
\hline 1996 & 332 & 196 & 19 & 26 \\
\hline 1997 & 1305 & 185 & 18 & 24 \\
\hline 1998 & 296 & 188 & 18 & 24 \\
\hline 1999 & 305 & 192 & 19 & 26 \\
\hline 2001 & 313 & 194 & 18 & 26 \\
\hline 2002 & 316 & 191 & 18 & 23 \\
\hline 2003 & 344 & 197 & 19 & 23 \\
\hline 2004 & 349 & 196 & 19 & 21 \\
\hline 2005 & 349 & 212 & 23 & 30 \\
\hline 2006 & 387 & 232 & 27 & 34 \\
\hline 2007 & 405 & 238 & 31 & 40 \\
\hline 2008 & 390 & 230 & 30 & 38 \\
\hline \multicolumn{5}{|c|}{ Pasture Canyon Spring } \\
\hline 1948 & ${ }^{1} 227$ & (2) & 5.0 & 13 \\
\hline 1982 & 240 & --- & 5.1 & 18 \\
\hline 1986 & 257 & --- & 5.4 & 19 \\
\hline 1988 & 232 & 146 & 5.3 & 18 \\
\hline 1992 & 235 & 168 & 7.1 & 17 \\
\hline 1993 & 242 & 134 & 5.3 & 17 \\
\hline 1995 & 235 & 152 & 4.8 & 14 \\
\hline 1996 & 238 & 130 & 4.7 & 15 \\
\hline 1997 & 232 & 143 & 5.3 & 17 \\
\hline 1998 & 232 & 147 & 5.1 & 16 \\
\hline 1999 & 235 & 142 & 5.1 & 14 \\
\hline 2001 & 236 & 140 & 5.1 & 17 \\
\hline 2002 & 243 & 143 & 5.1 & 16 \\
\hline 2003 & 236 & 151 & 5.1 & 16 \\
\hline 2004 & 248 & 150 & 5.5 & 16 \\
\hline 2005 & 250 & 149 & 5.1 & 16 \\
\hline 2008 & 240 & 149 & 5.0 & 18 \\
\hline
\end{tabular}

${ }^{1}$ Value is different in Black Mesa monitoring reports before 2000. Earlier reports showed values determined by laboratory analysis.

${ }^{2}$ Value is different in Black Mesa monitoring reports before 2000. Earlier reports showed values determined by the sum of constituents. 


\section{A. Dissolved Solids}

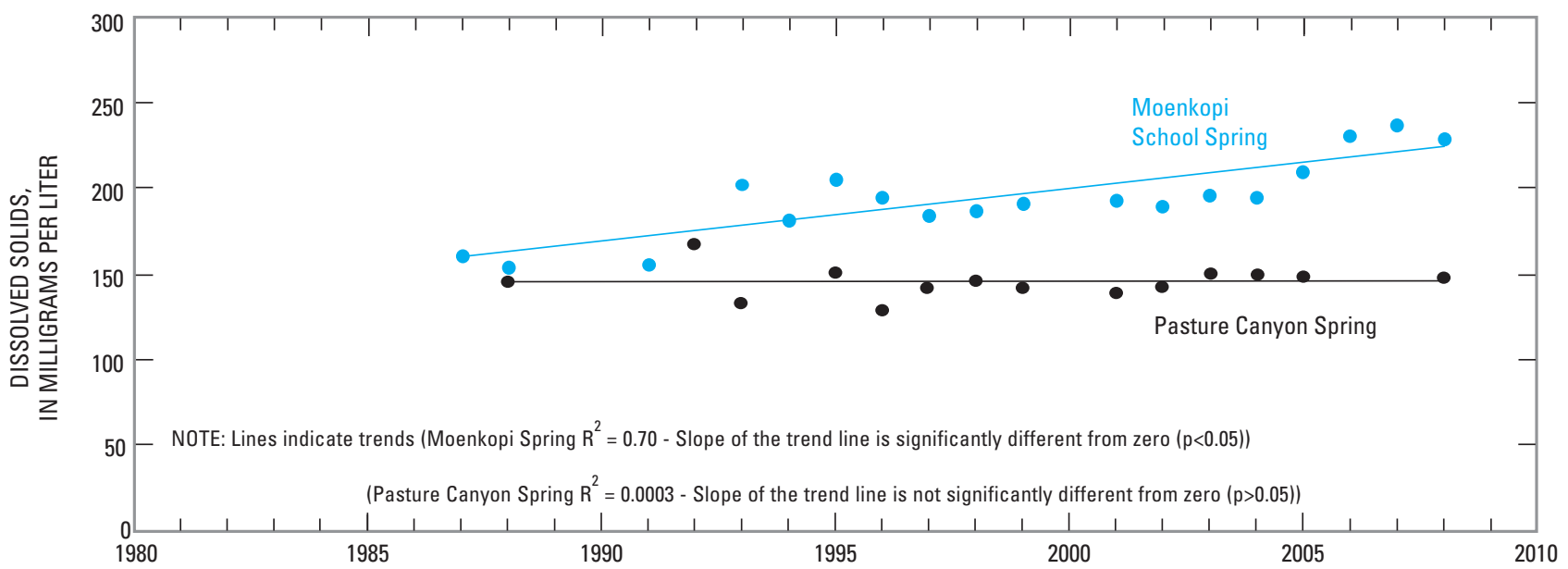

\section{B. Chloride}

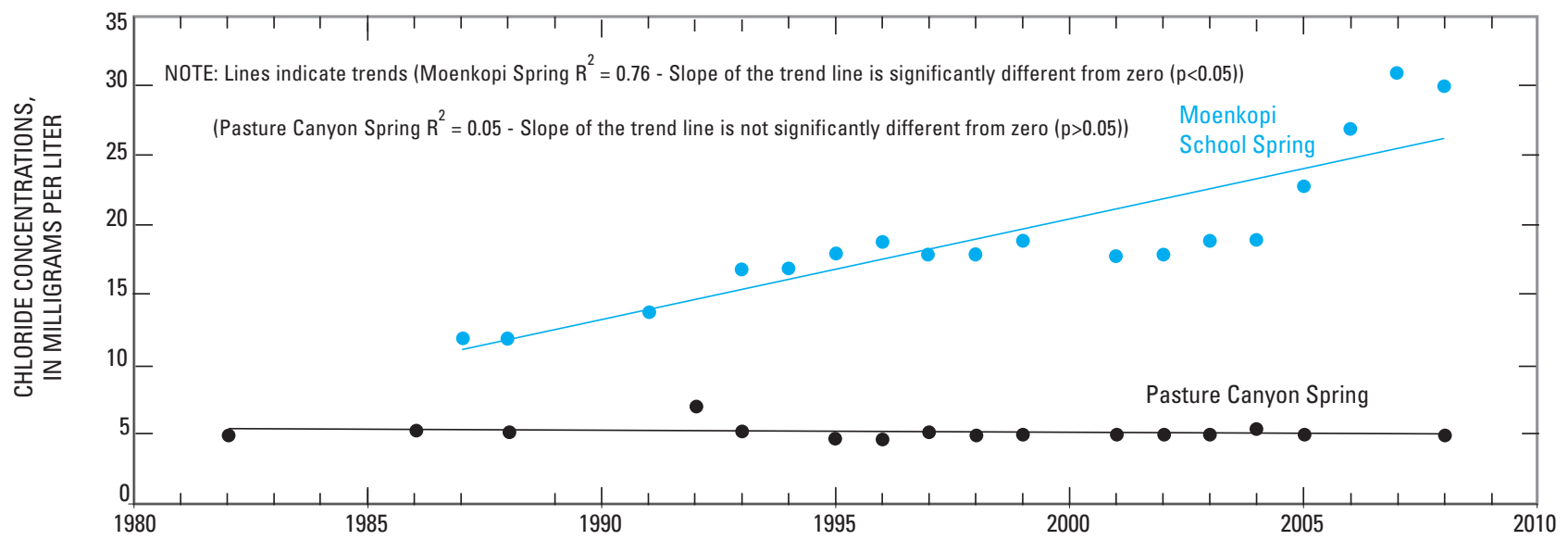

\section{Sulfate}

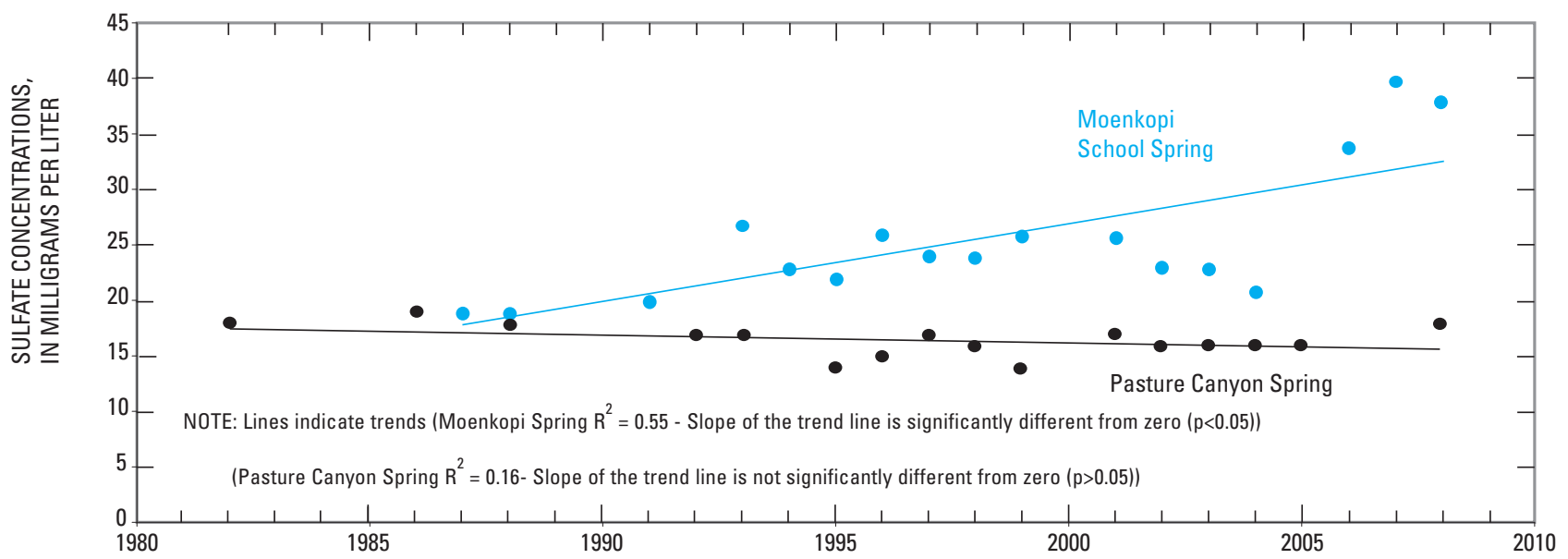

Figure 14. Concentrations of dissolved solids, chloride, and sulfate for water samples from Moenkopi School Spring and Pasture Canyon Spring, N aquifer, Black Mesa area, northeastern Arizona, 1982-2008. A, Dissolved solids; $B$, Chloride; $C$, Sulfate. (Trend lines were generated by using the method of least squares). 


\section{Summary}

The $\mathrm{N}$ aquifer is an extensive aquifer and the primary source of groundwater for industrial and municipal users in the Black Mesa area of northeastern Arizona. Availability of water is an important issue in the Black Mesa area because of continued industrial and municipal use, a growing population, and limited precipitation of about 6 to 14 inches per year.

This report presents results of groundwater, surfacewater, and water-chemistry monitoring in the Black Mesa area from January 2007 to September 2008. The monitoring data for 2007-8 are compared to data for 2006-7 and to historical data from the 1950s to September 2008.

In 2007, total groundwater withdrawals were 4,310 acre-ft, industrial withdrawals were 1,170 acre- $\mathrm{ft}$, and municipal withdrawals were 3,140 acre-ft. From 2006 to 2007, total withdrawals from the $\mathrm{N}$ aquifer increased by 5 percent, industrial withdrawals decreased by approximately 2 percent, and municipal withdrawals increased by 8 percent.

From 2007 to 2008, annually measured groundwater levels declined in 15 of 29 wells. The median water-level change for the 29 wells was $-0.2 \mathrm{ft}$. In unconfined areas of the $\mathrm{N}$ aquifer, water levels declined in 6 of 11 annual wells, and the median change was $-0.2 \mathrm{ft}$. In the confined area of the $\mathrm{N}$ aquifer, water levels declined in 9 of 18 wells, and the median change was $-0.2 \mathrm{ft}$.

From the prestress period (before 1965) to 2008, the median groundwater level change in 33 wells was $-12.9 \mathrm{ft}$. Water levels in the 15 wells in the unconfined areas of the $\mathrm{N}$ aquifer had a median change of $-1.0 \mathrm{ft}$, and the changes ranged from $-33.1 \mathrm{ft}$ to $+11.8 \mathrm{ft}$. Water levels in the 18 wells in the confined area of the $\mathrm{N}$ aquifer had a median change of $-33.2 \mathrm{ft}$, and the changes ranged from $-198.7 \mathrm{ft}$ to $+13.4 \mathrm{ft}$.

Discharge has been measured annually at Moenkopi School Spring and Pasture Canyon Spring. Between 2007 and 2008, spring flow decreased by 8 percent at Moenkopi School Spring and by 12 percent at Pasture Canyon Spring. For the period of record, discharge at Moenkopi School Spring and Pasture Canyon Spring has fluctuated, and the data indicate a decreasing trend in discharge for both springs.

Annual average discharges at four streamflow-gaging stations-Moenkopi Wash, Dinnebito Wash, Pasture Canyon Spring, and Polacca Wash - vary during the periods of record. No trends are apparent in streamflow at the four streamflowgaging stations. Median flows for November, December, January, and February of each water year are used as an indicator of groundwater discharge to those streams. For the period of record at each streamflow-gaging station, the median winter flows have generally remained constant, showing neither a significant increase nor decrease.

In 2008, water samples were collected from six wells and analyzed for selected chemical constituents. Concentrations of dissolved solids, chloride, and sulfate have varied for the period of record, and the data do not indicate a trend.
Dissolved-solids concentrations in the water samples from Moenkopi School Spring and Pasture Canyon Spring were $230 \mathrm{mg} / \mathrm{L}$ and $149 \mathrm{mg} / \mathrm{L}$, respectively. From the mid 1980s to 2008, long-term data from Moenkopi School Spring indicate increasing trends in concentrations of dissolved solids, chloride, and sulfate. Concentrations of dissolved solids, chloride, and sulfate from Pasture Canyon Spring do not indicate a trend for the period of record.

\section{References}

Boner, F.C., Davis, R.G., and Duet, N.R., 1992, Waterresources data for Arizona, water year 1991: U.S. Geological Survey Water-Data Report AZ-91-1, 411 p.

Boner, F.C., Garrett, W.B., and Konieczki, A.D., 1989, Waterresources data for Arizona, water year 1988: U.S. Geological Survey Water-Data Report AZ-88-1, 391 p.

Boner, F.C., Konieczki, A.D., and Davis, R.G., 1991, Waterresources data for Arizona, water year 1990: U.S. Geological Survey Water-Data Report AZ-90-1, 381 p.

Boner, F.C., Smith, C.F., Garrett, W.B., and Konieczki, A.D., 1990, Water-resources data for Arizona, water year 1989: U.S. Geological Survey Water-Data Report AZ-89-1, $383 \mathrm{p}$.

Brown, J.G., and Eychaner, J.H., 1988, Simulation of five ground-water withdrawal projections for the Black Mesa area, Navajo and Hopi Indian Reservations, Arizona: U.S. Geological Survey Water-Resources Investigations Report 88-4000, 51 p.

Cooley, M.E., Harshbarger, J.W., Akers, J.P., and Hardt, W.F., 1969, Regional hydrogeology of the Navajo and Hopi Indian Reservations, Arizona, New Mexico, and Utah: U.S. Geological Survey Professional Paper 521-A, 61 p.

Davis, G.E., Hardt, W.F., Thompson, L.K., and Cooley, M.E., 1963, Records of ground-water supplies, part 1 of geohydrologic data in the Navajo and Hopi Indian Reservations, Arizona, New Mexico, and Utah: Arizona State Land Department Water-Resources Report 12-A, 159 p.

Eychaner, J.H., 1983, Geohydrology and effects of water use in the Black Mesa area, Navajo and Hopi Indian Reservations, Arizona: U.S. Geological Survey Water-Supply Paper 2201, 26 p.

Fisk, G.G., Duet, N.R., Evans, D.W., Angeroth, C.E., Castillo, N.K., and Longsworth, S.A., 2004, Water-resources data for Arizona, water year 2003: U.S. Geological Survey WaterData Report AZ-03-1, 326 p. 
Fisk, G.G., Duet, N.R., McGuire, E.H., Angeroth, C.E., Castillo, N.K., and Smith, C.F., 2005, Water-resources data for Arizona, water year 2004: U.S. Geological Survey WaterData Report AZ-04-1, 415 p.

GeoTrans, Inc., 1987, A two-dimensional finite-difference flow model simulating the effects of withdrawals to the $\mathrm{N}$ aquifer, Black Mesa area, Arizona: Boulder, Colorado, GeoTrans, Inc., report prepared for Peabody Western Coal Company.

Harshbarger, J.W., Lewis, D.D., Skibitzke, H.E., Heckler, W.L., and Krister, L.R., 1966, Arizona water: U.S. Geological Survey Water-Supply Paper 1648, 85 p.

Hart, R.J., and Sottilare, J.P., 1988, Progress report on the ground-water, surface-water, and quality-of-water monitoring program, Black Mesa area, northeastern Arizona-1987-88: U.S. Geological Survey Open-File Report $88-467,27$ p.

Hart, R.J., and Sottilare, J.P., 1989, Progress report on the ground-water, surface-water, and quality-of-water monitoring program, Black Mesa area, northeastern Arizona-1988-89: U.S. Geological Survey Open-File Report 89-383, 33 p.

Hill, G.W., 1985, Progress report on Black Mesa monitoring program-1984: U.S. Geological Survey Open-File Report 85-483, 24 p.

Hill, G.W., and Sottilare, J.P., 1987, Progress report on the ground-water, surface-water, and quality-of-water monitoring program, Black Mesa area, northeastern Arizona-1987: U.S. Geological Survey Open-File Report 87-458, 29 p.

Hill, G.W., and Whetten, M.I., 1986, Progress report on Black Mesa monitoring program-1985-86: U.S. Geological Survey Open-File Report 86-414, 23 p.

HSIGeoTrans, Inc., 1993, Investigation of the N- and D-aquifer geochemistry and flow characteristics using major ion and isotopic chemistry, petrography, rock stress analyses, and dendrochronology in the Black Mesa area, Arizona: Boulder, Colorado, HSIGeoTrans, Inc., report prepared for Peabody Coal Company, 400.p.

HSIGeoTrans, Inc., and Waterstone Environmental Hydrology and Engineering, Inc., 1999, A three-dimensional flow model of the D and $\mathrm{N}$ aquifers, Black Mesa Basin, Arizona: Boulder, Colorado, HSIGeoTrans, Inc., and Waterstone Environmental Hydrology and Engineering, Inc., report prepared for Peabody Western Coal Company, 75 p.

Kister, L.R., and Hatchett, J.L., 1963, Selected chemical analyses of the ground water, part 2 of Geohydrologic data in the Navajo and Hopi Indian Reservations, Arizona, New Mexico, and Utah: Arizona State Land Department Water-Resources Report 12-B, 58 p.
Littin, G.R., 1992, Results of ground-water, surface-water, and water-quality monitoring, Black Mesa area, northeastern Arizona-1990-91: U.S. Geological Survey WaterResources Investigations Report 92-4045, 32 p.

Littin, G.R., 1993, Results of ground-water, surface-water, and water-quality monitoring, Black Mesa area, northeastern Arizona-1991-92: U.S. Geological Survey WaterResources Investigations Report 93-4111, 23 p.

Littin, G.R., Baum, B.M., and Truini, Margot, 1999, Groundwater, surface-water, and water-chemistry data, Black Mesa area, northeastern Arizona-1999: U.S. Geological Survey Open-File Report 98-653, 27 p.

Littin, G.R., and Monroe, S.A., 1995a, Results of groundwater, surface-water, and water-quality monitoring, Black Mesa area, northeastern Arizona-1992-93: U.S. Geological Survey Water-Resources Investigations Report 95-4156, $37 \mathrm{p}$.

Littin, G.R., and Monroe, S.A., 1995b, Results of groundwater, surface-water, and water-chemistry monitoring, Black Mesa area, northeastern Arizona-1994: U.S. Geological Survey Water-Resources Investigations Report 95-4238, $25 \mathrm{p}$.

Littin, G.R., and Monroe, S.A., 1996, Ground-water, surfacewater, and water-chemistry data, Black Mesa area, northeastern Arizona-1995: U.S. Geological Survey Open-File Report 96-616, 22 p.

Littin, G.R., and Monroe, S.A., 1997, Ground-water, surfacewater, and water-chemistry data, Black Mesa area, northeastern Arizona-1996: U.S. Geological Survey Open-File Report 97-566, 27 p.

Lopes, T.J., and Hoffmann, J.P., 1997, Geochemical analyses of ground-water ages, recharge rates, and hydraulic conductivity of the N Aquifer, Black Mesa area, Arizona: U.S. Geological Survey Water-Resources Investigations Report 96-4190, 42 p.

McCormack, H.F., Fisk, G.G., Duet, N.R., Evans, D.W., and Castillo, N.K., 2002, Water-resources data for Arizona, water year 2001: U.S. Geological Survey Water-Data Report AZ-01-1, 399 p.

McCormack, H.F., Fisk, G.G., Duet, N.R., Evans, D.W., Roberts, W.P., and Castillo, N.K., 2003, Water-resources data for Arizona, water year 2002: U.S. Geological Survey Water-Data Report AZ-02-1, 337 p.

Smith, C.F., Anning, D.W., Duet, N.R., Fisk, G.G., McCormack, H.F., Pope, G.L., Rigas, P.D., and Wallace, B.L., 1995, Water-resources data for Arizona, water year 1994: U.S. Geological Survey Water-Data Report AZ-94-1, 320 p. 
Smith, C.F., Boner, F.C., Davis, R.G., Duet, N.R., and Rigas, P.D., 1993, Water-resources data for Arizona, water year 1992: U.S. Geological Survey Water-Data Report AZ-92$1,360 \mathrm{p}$.

Smith, C.F., Duet, N.R., Fisk, G.G., McCormack, H.F., Partin, C.K., Pope, G.L., Rigas, P.D., and Tadayon, Saeid, 1996, Water-resources data for Arizona, water year 1995: U.S. Geological Survey Water-Data Report AZ-95-1, $306 \mathrm{p}$.

Smith, C.F., Duet, N.R., Fisk, G.G., McCormack, H.F., Partin, C.K., Pope, G.L., and Rigas, P.D., 1997, Water-resources data for Arizona, water year 1996: U.S. Geological Survey Water-Data Report AZ-96-1, 328 p.

Smith, C.F., Rigas, P.D., Ham, L.K., Duet, N.R., and Anning, D.W., 1994, Water-resources data for Arizona, water year 1993: U.S. Geological Survey Water-Data Report AZ-93-1, $360 \mathrm{p}$.

Sottilare, J.P., 1992, Results of ground-water, surface-water, and water-quality monitoring, Black Mesa area, northeastern Arizona-1989-90: U.S. Geological Survey WaterResources Investigations Report 92-4008, 38 p.

Tadayon, Saeid, Duet, N.R., Fisk, G.G., McCormack, H.F., Partin, C.K., Pope, G.L., and Rigas, P.D., 1999, Waterresources data for Arizona, water year 1998: U.S. Geological Survey Water-Data Report AZ-98-1, 454 p.

Tadayon, Saeid, Duet, N.R., Fisk, G.G., McCormack, H.F., Partin, C.K., Pope, G.L., and Rigas, P.D., 2000, Waterresources data for Arizona, water year 1999: U.S. Geological Survey Water-Data Report AZ-99-1, 389 p.

Tadayon, Saeid, Duet, N.R., Fisk, G.G., McCormack, H.F., Partin, C.K., Pope, G.L., and Rigas, P.D., 2001, Waterresources data for Arizona, water year 2000: U.S. Geological Survey Water-Data Report AZ-00-1, 390 p.

Tadayon, Saeid, Duet, N.R., Fisk, G.G., McCormack, H.F., Pope, G.L., and Rigas, P.D., 1998, Water-resources data for Arizona, water year 1997: U.S. Geological Survey WaterData Report AZ-97-1, 416 p.

Thomas, B.E., 2002a, Ground-water, surface-water, and water-chemistry data, Black Mesa area, northeastern Arizona-2000-2001, and performance and sensitivity of the 1988 USGS numerical model of the N aquifer: U.S. Geological Survey Water-Resources Investigations Report 02-4211, 75 p.

Thomas, B.E., 2002b, Ground-water, surface-water, and water-chemistry data, Black Mesa area, northeastern Arizona-2001-02: U.S. Geological Survey Open-File Report $02-485,43 \mathrm{p}$.
Thomas, B.E., and Truini, Margot, 2000, Ground-water, surface-water, and water-chemistry data, Black Mesa area, northeastern Arizona-1999: U.S. Geological Survey Open-File Report 00-453, 42 p.

Truini, Margot, Baum, B.M., Littin, G.R., and ShingoitewaHonanie, Gayl, 2000, Ground-water, surface-water, and water-chemistry data, Black Mesa area, northeastern Arizona-1998: U.S. Geological Survey Open-File Report 00-66, $37 \mathrm{p}$.

Truini, Margot, and Longsworth, S.A., 2003, Hydrogeology of the D aquifer and movement and ages of ground water determined from geochemical and isotopic analyses, Black Mesa area, northeastern Arizona: U.S. Geological Survey Water-Resources Investigations Report 03-4189, 38 p.

Truini, Margot and Macy, J.P., 2005, Lithology and thickness of the Carmel Formation as related to leakage between the $\mathrm{D}$ and $\mathrm{N}$ aquifer, Black Mesa, Arizona: U.S. Geological Survey Scientific Investigation Report 2005-5187, 7 p.

Truini, Margot, and Macy, J.P., 2006, Ground-water, surfacewater, and water-chemistry data, Black Mesa area, northeastern Arizona-2004-05: U.S. Geological Survey OpenFile Report 2006-1058, 42 p.

Truini, Margot, and Macy, J.P., 2007, Ground-water, surfacewater, and water-chemistry data, Black Mesa area, northeastern Arizona-2005-06: U.S. Geological Survey OpenFile Report 2007-1041, 42 p.

Truini, Margot, and Macy, J.P., 2008, Ground-water, surfacewater, and water-chemistry data, Black Mesa area, northeastern Arizona-2006-07: U.S. Geological Survey OpenFile Report 2008-1324, 33 p.

Truini, Margot, Macy, J.P., and Porter T.J., 2005, Groundwater, surface-water, and water-chemistry data, Black Mesa area, northeastern Arizona-2003-04: U.S. Geological Survey Open-File Report 2005-1080, 44 p.

Truini, Margot, and Thomas, B.E., 2004, Ground-water, surface-water, and water-chemistry data, Black Mesa area, northeastern Arizona - 2002-03: U.S. Geological Survey Open-File Report 03-503, 43 p.

U.S. Department of Agriculture, Natural Resources Conservation Service, 1999, Arizona annual precipitation: Fort Worth, Texas, USDA-NRCS National Cartography \& Geospatial Center, scale 1:1,300,000.

U.S. Environmental Protection Agency, 2003, Current drinking water standards, national primary and secondary drinking water regulations: Washington, D.C., U.S. Environmental Protection Agency [http:// www.epa.gov/safewater/mcl. html 02:30P, last accessed October 30, 2008]. 
U.S. Geological Survey, 1963-64a, Surface-water records of Arizona: U.S. Geological Survey report, 191 p.

U.S. Geological Survey, 1963-64b, Ground-water records of Arizona: U.S. Geological Survey report, 80, p.

U.S. Geological Survey, 1965-74a, Water-resources data for Arizona-Part 1, surface-water records: U.S. Geological Survey Water-Resources Data Report, 212, p.

U.S. Geological Survey, 1965-74b, Water-resources data for Arizona-Part 2, ground-water records: U.S. Geological Survey Water-Resources Data Report, 89, p.

U.S. Geological Survey, 1976-83, Water-resources data for Arizona, water years 1975-81: U.S. Geological Survey WaterResources Data Reports AZ-75-1 to AZ-81-1, 440 p .

U.S. Geological Survey, 1978, Progress report on Black Mesa monitoring program -1977: U.S. Geological Survey OpenFile Report 78-459, 38 p.

White, N.D., and Garrett, W.B., 1984, Water resources data for Arizona, water year 1982: U.S. Geological Survey Water-Data Report AZ-82-1, 440 p.

White, N.D., and Garrett, W.B., 1986, Water resources data for Arizona, water year 1983: U.S. Geological Survey Water-Data Report AZ-83-1, 387 p.
White, N.D., and Garrett, W.B., 1987, Water resources data for Arizona, water year 1984: U.S. Geological Survey Water-Data Report AZ-84-1, 381 p.

White, N.D., and Garrett, W.B., 1988, Water resources data for Arizona, water year 1985: U.S. Geological Survey Water-Data Report AZ-85-1, 343 p.

Wilson, R.P., and Garrett, W.B., 1988, Water resources data for Arizona, water year 1986: U.S. Geological Survey WaterData Report AZ-86-1, 341 p.

Wilson, R.P., and Garrett, W.B., 1989, Water-resources data for Arizona, water year 1987: U.S. Geological Survey Water-Data Report AZ-87-1, 385 p.

Zhu, Chen, Waddell, R.K., Star, I., and Ostrander, M., 1998, Responses of ground water in the Black Mesa Basin, northeastern Arizona, to paleoclimatic changes during the late Pleistocene and Holocene: Geology, v. 26, no. 2, p. $127-130$.

Zhu, Chen, 2000, Estimate of recharge from radiocarbon dating of groundwater and numerical flow and transport modeling: Water Resources Research, v. 36, no. 9, p. 2607-2620. 
